Rhode Island College

Digital Commons @ RIC

Master's Theses, Dissertations, Graduate

Master's Theses, Dissertations, Graduate

Research and Major Papers Overview

Research and Major Papers

8-31-2018

\title{
Effects of Spirituality on Patients' Health Outcomes
}

Eddie Jossee Charles

Follow this and additional works at: https://digitalcommons.ric.edu/etd

Part of the Other Nursing Commons

\section{Recommended Citation}

Charles, Eddie Jossee, "Effects of Spirituality on Patients' Health Outcomes" (2018). Master's Theses, Dissertations, Graduate Research and Major Papers Overview. 289.

https://digitalcommons.ric.edu/etd/289

This Major Paper is brought to you for free and open access by the Master's Theses, Dissertations, Graduate Research and Major Papers at Digital Commons @ RIC. It has been accepted for inclusion in Master's Theses, Dissertations, Graduate Research and Major Papers Overview by an authorized administrator of Digital Commons @ RIC. For more information, please contact digitalcommons@ric.edu. 


\section{EFFECTS OF SPIRITUALITY ON PATIENTS’ HEALTH OUTCOMES}

by

Eddie Josee Charles

A Major Paper Submitted in Partial Fulfillment

of the Requirements for the Degree of

Master of Science in Nursing

in

The School of Nursing

Rhode Island College

2018 


\begin{abstract}
Spirituality is a concept that is recently getting increased attention. Often misunderstood or confused with other concepts such as religion or culture, it has a broader meaning and transcends culture, religion, and geographic boundaries. The importance of spirituality in patient care remains controversial amongst providers. An integrative review of the literature was conducted to examine the impact of spirituality on health outcomes. Literature was searched over a 20 year period using CINAHL and PUBMED. The framework that guided this project was Martha Rogers’s Theory of Unitary Human Being that focuses on the interaction between individuals and their environment. In the method section, terms often confused with spirituality were described. Ten articles that described the effects of spirituality on health outcomes and that met the inclusion and exclusion criteria were analyzed. The included literature was critiqued using the Polit and Beck appraisal tool and presented in tables, then a cross-analysis of these articles was conducted and described. The literature supported that there are numerous positive outcomes, physical or psychological associated with spirituality. The implications and recommendations for advanced practice were also discussed.
\end{abstract}




\section{Acknowledgements}

I'd like to thank my family for their prayers. I could never make it without their support. I'm also thankful to Dr. Cynthia Padula and Dr. Galloway, my first and second readers, who believed in this project and helped me realize it. Special thanks to Dr. Debra Servello, my advisor for three years for her continuous support and encouragement. 


\section{Table of Contents}

Background/Statement of the Problem .................................................................. 1

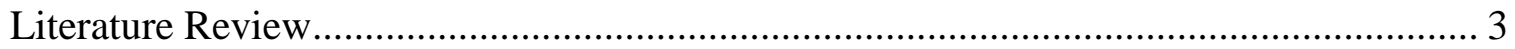

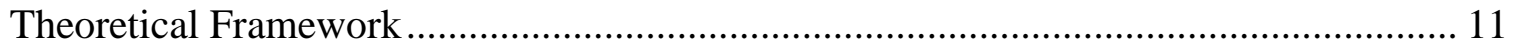

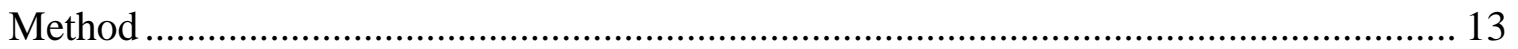

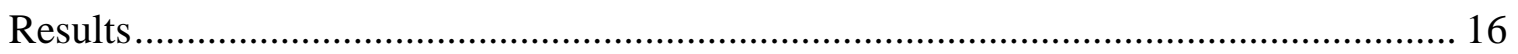

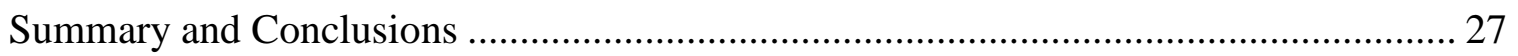

Recommendations and Implications for Advanced Nursing Practice ............................. 31

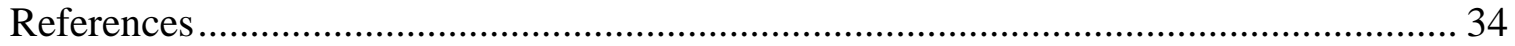

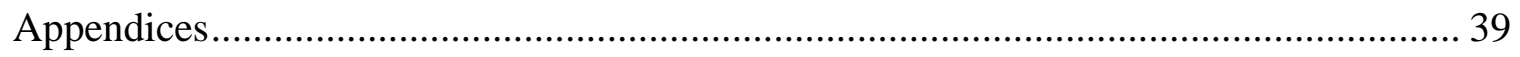




\section{Effects of Spirituality on Patients’ Health Outcomes}

\section{Background/ Statement of the Problem}

To provide holistic care to patients, several components have to be included in the plan of care. A comprehensive patient assessment demands that healthcare professionals pay attention to individuals’ needs, whether they are physical, emotional or spiritual. It is important to acknowledge that physical needs are more visible and often tend to be prioritized over less obvious ones such as spiritual needs. Sometimes, physical symptoms have their roots in non-visible wounds that providers need to assess and treat in the same way that they take care of the more obvious ones. The body cannot heal harmoniously without all its parts being acknowledged. It is critically important for nurses to assess patients' spiritual needs and ensure that they are met.

Spirituality is a concept that is difficult to conceptualize in one simple definition. It can be influenced by personal experiences, faith, culture and background. Providers have to look further into the patients' story to find out what spirituality means to them and how to care for their spiritual needs. The sensitive nature of the concept of spirituality and a lack of knowledge about it are sometimes regarded as barriers that discourage providers from investigating, thinking that they would be too intrusive (Alistair, 2016). Making it even more challenging to define is the fact that spirituality is often mistaken for other related concepts such as religion, culture and faith. Alistair described another barrier to assessing spirituality as a form of bias that considers spirituality as a practice endorsed by people who are less capable intellectually. It is also suggested that in practice, providers usually have a positive opinion of spirituality, while 
they may have a rather opposite viewpoint about religion, which is sometimes a channel to express spirituality.

Spiritual beliefs are part of the individual's value system and may influence beliefs about healing, causes of diseases, and even the choice of a provider (Blais \& Hayes, 2011). That is the reason spiritual care is such an important part of nursing. Providing spiritual care is not only a nursing duty, but also a requirement of the Nurses Code of Ethics (2015). Cowling (2010) described increased specialization of care as another factor that keeps the provider from addressing patients' needs in a comprehensive manner. According to Cowling, the patients' care is so compartmentalized that important aspects such as spirituality, that highlights individual uniqueness, are neglected.

Prioritization of physical needs, which are obvious, over non-physical ones is a factor that explains the fact that although spirituality in an old concept, nursing and other disciplines hesitated for years before integrating it into healthcare practices (Treloar, 2000). The purpose of this project is to conduct an integrative review to examine the effects of spirituality on health outcomes.

Next, the review of literature will be presented and discussed. 


\section{Literature Review}

The inquiry for this project started by searching the databases CINAHL and PUBMED, using the terms the terms spirituality, adults and health outcomes. The literature search included publications over a period of 20 years, from January 1997 through December 2017.

\section{Defining Spirituality}

Traditionally, spirituality has been associated or mistaken with religion. For some people, spirituality cannot be conceived outside the realm of a religious connection or belief (O’Brien, 1999). Currently, more and more individuals describe themselves as spiritual although they who do not consider themselves religious (Narayanasamy, 2004). There is not a universal definition of spirituality that is agreed upon. Tanyi (2002) described spirituality as a personal quest for purpose in one's life in the presence of a religious affiliation or not. Narayanasamy (2004) referred to spirituality as a universal experience that transcends race, religion and nationality. Barnum (2003) defined spirituality as a search for connection with a greater and meaningful context, while Mauk and Schmidt (2004) explained it as the core of a person's existence involving his relationship with a higher power. Some nursing scholars have attempted to provide a definition of the concept spirituality, but the problem remains to completely separate it from religion (Pike, 2011). One perspective views spirituality as “a repository of positive feelings such love, compassion, caring, and a connection between the body, the mind and the spirit”(O’Brien, 2008, p.5). 


\section{Related Concepts}

Religion and faith are concepts that have always been closely tied to spirituality. There are in fact some similarities, but those terms are not synonyms. Religion is defined as a personal set or institutionalized system of religious beliefs, attitudes and practices (Merriam-Webster Dictionary, n.d).Religion has been described as “an organized system of beliefs regarding the cause, purpose, and nature of the universe that is shared by a group of people, and the practices, behaviors, worship, and ritual associated with that system”(Burkhardt \& Nagai-Jacobson, 2009, p. 617). Faith is characterized as a deeper and more personal experience than religion that involves a closer relationship with a higher power (O’Brien, 1999). According to Mauk and Schmidt (2004), faith is belief in something that cannot be directly observed.

The term culture is also mistaken for spirituality at times. It is described as attitudes, values and goals that are shared by a group of individuals or an institution (Merriam-Webster, n.d.). Leininger (1988)defined culture as the sum of values, beliefs, and norms that are learned, shared, and transmitted, and practices of a particular group that guide thinking, decisions, and actions. According to the Office of Minority Health, culture is “ the integrated patterns of human behavior that include the language, thoughts, communications, actions, customs, beliefs, values, and institutions of racial, ethnic, religious, or social groups”(USDHHS, 2005). This suggests that spirituality is a more universal concept, transcending race, nationality, and language. 


\section{Expressions of Spirituality}

As a universal and personal experience, spirituality may be expressed through religion. When it is expressed through a religious channel, it can take the forms of prayers and meditation where people communicate with a higher power, whether it is called God, Allah, or Jehovah (Blais \& Hayes, 2011). There are other expressions of spirituality that are not related to any religious affiliations although they are also practiced by religious people. These are called mind-body therapies based on the premises that the mind and the body are connected (Blais \& Hayes). Consistent with the National Center for Complementary and Alternative Medicine (NCCAM), "the most common mind-body therapies are music, guided imagery or guided self-healing, meditation, prayer, art, music, and, dance therapy” (NCCAM; cited in Blais \& Hayes, 2011). Music, as an artistic expression, is considered as a form of universal expression. It affects emotions, touches lives and connects people regardless of culture or race, allowing it to be used in a variety of settings, particularly in end-of life care and chronic illnesses (McClean, Bunt \& Daykin, 2012).

Bruckental, Marino \& Snelling (2016) described guided imagery as a technique that can be used to teach patients how to replace negative thoughts with positive ones through suggestions and visualization. It also empowers them in order to be able to take care of themselves. Prayers and meditation are at the center of religious life, but are also considered as a form of mind-body therapy (Blais \& Hayes, 2011). Guided imagery is a line of communication that people from different religious affiliations use to reach to God or any other higher power they believe in, although its classification as another type complementary and alternative therapy is still controversial (Jors et al.,2015). Prayers 
may take different forms depending on the individual's system of beliefs and the Superior Being it is addressed to. The words expressed in a prayer are directly related to the needs of the one offering the prayer (Dossey, 1993).

\section{Spiritual Assessment}

Performing a comprehensive assessment in order to provide holistic care is at the center of the Nurses Code of Ethics. Whenever spiritual and physical needs are met, the outcome will be an improved health state. Although spiritual care is very important in healthcare, there are very few reliable tools used in practice (Draper, 2012). Tanyi (2006) developed a guideline for assessing spiritual needs for the entire family in which she described spirituality as “a family phenomenon” (p.288) and provided a list of questions related to the family's values.

Several models are used to assess patients' spirituality. One of them is HOPE that Anandarajah and Hight (2001) described as a basic inquiry to help healthcare providers to start the conversation about spirituality. The ' $\mathrm{H}$ ' stands for sources of hope, strength, comfort, and meaning. The 'O' represents organized religion, "P” for personal spirituality or practices and the” E” effects on care and end-of-life decisions. This tool provides a direct access into the patients' spiritual background, allowing one to investigate the role that spirituality may have in the patients' perception of health and illness. Patients are asked to answer directly to questions regarding their spiritual practices, their coping strategies and whether they practice any religion.

Another assessment tool used to assess patients' spirituality is the FICA Spiritual History Tool. This was introduced by Dr. Puchalski and a group of primary care physicians in 1996 to assess patients' spiritual well-being. In this acronym, the F 
represents for faith and belief and the I stands for the importance that spirituality holds in the patient's life. The $\mathrm{C}$ is for community, highlighting the importance of being part of a group. The A stands for address in care, meaning that the spiritual assessment must lead to the integration of spiritual care into patients’ care plan (Puchalski, 1996).

Maugans (1996) developed the SPIRIT model to assess spirituality. In the acronym SPIRIT, S stands for spiritual belief system, P for personal spirituality, I for integration and involvement in a spiritual community, $\mathrm{R}$ for ritualized practices and restrictions, I for implications for medical care, T for terminal events (Maugans; as cited in Blais \& Hayes, 2011).These three assessment tools are frequently mentioned in the literature to provide guidance for spiritual assessment (Chrash, Mulich \& Patton, 2011).

Shelly and Fish (1988) developed a patient-centered tool for assessing spiritual needs from a nursing perspective that takes into account parameters like patients’ environment, their behavior, the verbalization of needs and interpersonal relationships. Environment includes the objects that patients are surrounded with that can provide clues about their beliefs while behavior refers to any special diet or prayer habits. Verbalization includes the patient's response to pain or other experiences. The interpersonal relationships are perceived as the way the patient engage with family members, providers, and roommates.

David Hodge (2013) proposed an implicit spiritual assessment which outlines where providers are encouraged to assess spirituality whenever patients are emotionally available to discuss their beliefs and their values. Other scholars like Blaber, Jones and Willis (2015) advocated for a more personal dialogue with the patient and consider formal assessment tools as guidelines to introduce the concept of spirituality. They 
warned against the use of those materials as admission checklists that limit the interactions with the patient.

There is not a specific spiritual assessment tool used in nursing. While there are several formal tools in the literature such FICA or HOPE assessment tools, many nurses scholar favor a less formal approach in assessing spiritual needs (Timmins \& Caldeira, 2017). Timmins and Caldeira discussed a formal assessment tool titled "SHALOM" that stands for Spiritual Health and Life-Orientation Measure. This20-item survey focuses on four dimensions: personal; communal; environmental; and transcendental. Timmins and Caldeira further encouraged that spiritual assessment should be an ongoing process rather than simply part of an admission checklist, which would be impossible without developing a trusting relationship with the patient.

\section{Spiritual Care}

Providing spiritual care has always been one of the objectives of nursing in the context of a holistic approach, but has become increasingly important given the role that spirituality plays in people’s lives (Blais \& Hayes, 2011). Providing spiritual care involves everyone in the healthcare team and should be tailored to the patients' specific needs, since there are different approaches to spiritual care. Some patients may respond better to prayers and meditation, while others may prefer music or art therapy which may also be viewed as expressions of spirituality (Lane, 2005). Mary Rockwood Lane talks about creativity when it comes to providing spiritual care in "Creativity and Spirituality in Nursing” (2005).In order to provide spiritually competent care, the nurse has to take into account any bias she may have about spirituality and address them. It is also important that patients are provided with the appropriate environment to fulfill their 
spiritual needs. The provider has to be present, supportive and provide any necessary assistance (Mauk \& Schmidt, 2004). Nurses are encouraged to be creative when providing spiritual care because there are many ways to address patients’ spiritual needs whether it is by music, prayers, or just by providing a comforting presence.

Blais and Hayes (2011) described nurses’ attitudes that favor good spiritual care, such as being available, providing privacy when needed, informing patients about available resources and respecting patients’ belongings that have spiritual meanings. Nursing care is influenced by many spiritual practices that the nurse has to acknowledge in order to deliver patient-centered care. Beliefs related to diet, reactions to painful stimuli, childbirth and the experience with death are examples of spiritual beliefs that the nurse needs to investigate in order to better educate patients and advocate on their behalf (Blais \& Hayes, 2011). Spiritual care is not uniquely a nursing duty and sometimes, referral to another provider is necessary to better address patients’ concerns and needs (Timmins \& Caldeira, 2017).

\section{Effects of Spirituality on Health Outcomes}

Spirituality as a broad concept can be applied to any aspect of an individual's life. The effects of spirituality on health outcomes can be measurable such as in cases where the heart rate slows down or the blood pressure decreases or can be less measurable in the case of improved mood (Lane, 2005).

Snider and Mc Phedran (2014) studied the effects of spirituality and religiosity on health outcomes, using a systematic review of articles published in Australia. They gathered information from 13 articles deemed relevant to their inquiry. Among those articles, six were analyzed based on the inclusion criteria previously established. Certain 
terms like religiosity/spirituality, psychiatric/psychological health and/or treatment outcomes were among those they have searched. The participants were surveyed or interviewed, and answered questions related to their spirituality or religiosity in relationship to their health outcomes.

Although the respondents were chosen from different settings, and experienced spirituality at different levels, and while diverse methods of data collection were used, the common theme that emerged from those six articles was that spirituality influenced peoples' health in a positive way. Some participants who stated that they believed in God reported a higher sense of psychological well-being. Others suggested that being spiritual protected s against physical and mental illnesses and helped them develop better coping strategies.

Mary Rockwood Lane (2005) described the effects of spirituality through art such as music or dance therapy can have on the healing process. She explained that those expressions of spirituality can directly lower heart rate, blood pressure and produce a state of deep relaxation. Lane noted that dance and music have been used for centuries for the same purpose of healing, while nursing has just started to discover the powerful healing power of guided imagery and prayers. She encouraged nurses to act as creative agents, willing to integrate activities that engage patients and allow self-expression. Next, the theoretical framework will be discussed. 


\section{Theoretical Framework}

The theory that served as a guide for this project is Rogers' 'Theory of Unitary Human Beings' that focuses on the interaction between individuals and their environment. Martha Rogers introduced this theory in 1970, which was inspired from sociology, psychology, religion, astronomy and other disciplines in the same year that the concept of holistic care started to gain much more attention from the healthcare community (Blais \& Hayes, 2011). This new school of thought clearly was a break from the tradition that only focused on treating the body.

Rogers considers human beings as indivisible entities, meaning that the physical and the spiritual should not be separated (Blais \& Hayes, 2011). She emphasized her theory's implication for nursing by pointing out that nurses have to focus on the individual as a whole. Trying to relieve only the physical aspect of suffering while ignoring the spiritual part can only delay or complicate the treatment. Throughout her book titled An Introduction to the Theoretical Basis of Nursing, Rogers emphasized the connection between people and the environment. She stated "People are inseparable from the natural world” (Rogers, 1970, p.49). This statement supports some of the characteristics of spirituality cited by Blais and Hayes (2011), in their book Professional Nursing Practice, such as connectedness to the environment, connectedness to a Supreme Being, connectedness to others and personal connectedness. Rogers (1970) later stated that "Man-environment transactions are characterized by continuous repatterning of both man and environment” (p. 53). 
Nursing has expanded its purpose to become a multidimensional discipline that champions the principles of holistic care (Blais \& Hayes, 2011). Holistic care paved the way for complementary and alternative medicine that combine Western medicine practices previously more focused on healing the body and the Eastern medicine conception based on the spiritual aspect of healing (Blais \& Hayes, 2011). As our society is becoming more and more spiritually diverse, nurses and healthcare providers in general have to be more knowledgeable about spiritual rituals and the beliefs that support them in order to provide patient-centered care.

Next, the method will be presented. 


\section{Method}

\section{Purpose}

The purpose of this project was to conduct an integrative review to examine the impact of spirituality on health outcomes.

\section{Definition of Terms}

Barnum (2003) defined spirituality as “a person’s search for, or expression of, his connection to a greater and meaningful context” (p. 1).

Religion has been described as "an organized system of beliefs regarding the cause, purpose, and nature of the universe that is shared by a group of people, and the practices, behaviors, worship, and ritual associated with that system”(Burkhardt \& NagaiJacobson, 2009, p. 617).

Faith is characterized as a deeper and more personal experience than religion that involves a closer relationship with a higher power (O’Brien, 1999).

Leininger (1988) defined culture as the sum of values, beliefs, and norms that are

learned, shared, and transmitted, and practices of a particular group that guide thinking, decisions, and actions.

\section{Inclusion Criteria}

The inclusion criteria included articles or studies examining spirituality in adults and impact on health outcomes, including physical and emotional symptom improvement. Articles included for review were evidence-based and studies of any design were included. 
The exclusion criteria included articles or studies that covered the pediatric population and that did not specifically address the impact on health outcomes.

\section{Design}

The model that was used for this project was an integrative review format in which a comprehensive review of the literature focusing on the effects of spirituality on health outcomes was examined.

\section{Detailed Search Strategy}

The studies and articles for this project were selected through searching the databases CINAHL and PUBMED over 20 years, specifically from January 1997 to December 2017. The keywords spirituality, health outcomes, and adults were used. Some terms were combined such as spirituality and health, spirituality and health outcomes, and spiritual care and health outcomes.

\section{Data Collection}

A data collection table was illustrated for each article identified for inclusion in the review. The table included items such as, type of publication, literature review, qualitative study or quantitative study; how spirituality was defined; the target sample; and what health outcomes were identified.

\section{Assessment criteria/critical appraisal tool}

The critique of the selected articles included an appraisal of the strength and the weakness of the different studies and articles. A thorough analysis of the ten articles that described the effect of spirituality on health outcomes were presented in tables in the appendix section. Qualitative and quantitative studies were critiqued according to the detailed critiquing guidelines presented in Polit and Beck (2017). A qualitative method 
of critiquing is presented in this book, where the authors suggested a point-by-point analysis of the different parts of the study or article from the title to the findings and their interpretation. They also presented a quantitative method where every part is analyzed critically as well. While both methods insist on protecting the rights of participants, in the discussion section, the presentation of findings differs. In a qualitative review, they talk about transferability of findings, while in a quantitative model the focus is more on their generalizability. Those parts were reviewed separately and thoroughly appraised not only for the writing style, but also for the depth of the subject. Particular attention was paid to the way the topic of spirituality in relationship to health outcomes was addressed. Once the review of the individual articles was completed, they were examined for similarities and differences. It was determined whether the studies and articles were relevant to nursing practice and whether the findings could be applied to nursing in a practical manner.

Next, the results will be presented. 


\section{Results}

There has been an increased interest in studying spirituality in recent years. This renewed interest can be linked to the introduction of holistic care as a new approach to care that allows to explore other alternatives to the traditional ways of improving patients' health outcomes. Spirituality is often difficult to define given that it is an abstract concept. There are also a lot of controversies surrounding this topic in relation to its application to daily life. In the following section, each article included in this review will be briefly described, with major findings illustrated. After all articles have been reviewed, a cross-study analysis will be conducted.

Ironson, Stuetzle, and Fletcher (2006) (Appendix A-6) used a longitudinal design to explain how spirituality can affect health outcomes. A sample of 100 participants infected with the HIV virus were chosen and criteria including religiousness/spirituality at various times in life, CD4 and viral load, the ability to cope, and social support were used to measure disease progression. Forty-five percent $(n=45)$ of the participants reported an increase in spirituality/religiousness following diagnosis; in 42\% $(n=42)$ of the sample, spirituality was unchanged, while $13 \%(n=13)$ were less religious than before. The findings of this study show a relationship between an increase in spirituality and an improvement in CD4 levels and lower viral load. Fifty percent $(n=50)$ of people affected with HIV reported that increased religiousness/spirituality prolonged their lives by lowering their viral load and increasing their CD4 level: 1.39 CD4 cells were preserved per month or 16 CD4 cells per year. Inversely, people with a decrease in spirituality lost CD4 cells 4.5 times faster than those who were more religious/spiritual. It was unclear whether an increase in spirituality by itself could affect viral load and CD4 
level without considering other items generally associated with a change in spirituality. These could include a new conception of life, of others and of self, a new conception of God, a new sense of inner values that is translated by behaviors like safer sex practices, smoking cessation, and getting off drugs, and adherence to treatment.

Watlington and Murphy (2006) (Appendix A-4) examined spirituality/religiousness in African American survivors of domestic violence. The authors focused on the effects of abuse such as depression, anxiety, substance abuse, suicidal thoughts, and the coping strategies used by those women. Sixty-five African American women recruited from diverse domestic abuse facilities in Maryland and Washington were surveyed through questionnaires where they provided sociodemographic data, the type of abuse they have endured, and their coping strategies. The authors found out that religion and spirituality played a central role in helping those women deal with the consequences of violence. GPower analysis was used to determine the sample size. They found a positive relationship between religious involvement and social support $(\mathrm{r}=.41, \mathrm{p}<.01)$, and a connection with a higher being supported a lower level of depression $(r=-.29, \mathrm{p}<.05)$. The limitations of this study were the sample size, the sampling method that limited the access to other groups of African American women, and the design itself.

Roudsari, Allan, and Smith (2007) (Appendix A-9) reviewed the literature related to the topic of infertility. They pointed out that little attention has been given to the religious and spiritual dimensions of infertility in the literature, while the focus has always been on its medical, psychological, and social consequences. They discussed religion and spirituality as coping mechanisms used by women affected by infertility. Religion/spirituality also influences these women’ decision when it comes to the choice 
of a medical treatment to their infertility: some religions allow in vitro fertilization, while others such as Judaism and Islamism prohibit it unless the egg and the sperm come from the couple. These women often simultaneously turn to prayers and spiritual healers for healing. Several studies reviewed reported that people believe in prayers to heal infertility. The authors noted that other researchers reported that religion/spirituality is a source of support for infertile women, while some women perceive infertility as a punishment from God. This review also touched on the caregiver role on assessing and acknowledging the patients' spiritual needs.

Koening (2009) (Appendix A-7) discussed the relation between religion, spirituality and mental diseases, particularly depression, suicide, anxiety, psychosis, and substance abuse. The author defined the concepts religion and spirituality and provided a timeline of the introduction of religion/spirituality in psychiatric care. Similar to other illnesses, spirituality is used as a coping strategy in mental health. A sample of 406 patients $(n=406)$ surveyed at a California mental health clinic 80\% $(n=324)$, acknowledged that they used religion to cope with their illness. The author referred to the event on September $11^{\text {th }}, 2001$ to say that $90 \%$ of Americans turned to religion to cope with the stress generated by the attacks, while $60 \%$ attended church, and Bible sales increased to $27 \%$. Examining the direct impact of spirituality and religion on mental illnesses in diverse studies, the authors found that people who were described as more religious were less likely to show depressive symptoms, cautioning that those data were collected within communities with lower stress levels. Sixty-eight studies examining suicide-religion relation found fewer suicides among people identified as more religious. Other studies found that people pray more when dealing with stressful situations, 
consequently they experienced an increased sense of control and safety. According to Koening, religion and spirituality are protective factors against self-destructive behaviors such as substance abuse.

Snider and McPhedran (2013) (Appendix A-5) discussed the influence of religion/spirituality on mental health in Australia. The authors reviewed the literature and acknowledged that there were fewer sources in Australia than the United States of America when it came to data about religion/spirituality and mental health. Moreover, they identified some differences between Australia and the United States in terms of church attendance and belief in God. More people attended church in the United States (90\%), compared to Australia where 70\% of people reported that they believed in God. A total of six studies that met the inclusion criteria were considered in this review. The authors concluded that there was a positive association between a relationship with God or a higher power and psychological well-being. In one study,75 \% of participants acknowledged that spirituality/religion was important to them and $80 \%$ stated that it affected their health. The authors also noted that religion/spirituality may protect against mental illnesses.

Jim et al. (2013) (Appendix A-3) discussed religion, spirituality, and physical health in cancer patients. Studies were included in this review if they included adults $>18$ years old with a diagnosis of cancer and were undergoing treatment at the time of the study. Data were collected from 101 samples grouping about 32.000 patients and the focus was to summarize the relationship between religion/spirituality and health outcomes where religion/spirituality was described in terms of its behavioral, affective and cognitive component. Health outcomes were classified in terms of physical, mental, 
or social effects. A generalized estimating equation (GEE) was the tool used to analyze the effect size between religion/spirituality and physical health. The authors concluded that a higher level of religion/spirituality was associated with better physical well-being. Affective religion/spirituality was the most closely related to physical health $(z=0.167$, $\mathrm{p}<.001$ ), while the cognitive component was associated with functional and physical well-being, but not physical symptoms $(\mathrm{z}=0.079, \mathrm{p}<.05)$. The authors strongly recommended religious and spiritual support for cancer patients regardless of the disease stage.

De Fazio et al. (2014) (Appendix A-8) studied the relationship between religion/spirituality and bipolar disorder. The authors discussed the negative perception that people usually hold towards religion, while spirituality had a more favorable view particularly in recent years. Five studies were selected for this review where the emphasis was on religious involvement as a preventive tool for mental illness. The Duke Religious index, the Internal State Scale, and the World Health Organization Quality of Life were used to analyze the data in some cases. The first study examined patients with pervasive affective disorders and their religious experiences. The four other studies focused on those affected by bipolar disorder and tried to find out how their religious beliefs could affect the disease course. One of the findings was that religious involvement could be helpful in mental health in three areas: depression; substance abuse; and suicide. The authors reported that although these studies had a different design, they all concluded that religion/spirituality was very important to those patients and that it affected their quality of life and improved their symptoms. 
Jors, Bussing, Hvidt, and Bauman (2015) (Appendix A-1) introduced their topic by stating that personal prayers could have positive and negative consequences on patients' well-being. They provided a definition of prayer and divided it in different categories: prayers for oneself, prayers of others for oneself, and prayer group that people engage in time of illness. A total of 16 studies were part of this inquiry. The main question was to find out what kind of prayers patients engage in, why they pray, and how they pray? The data were collected through semi-structured interviews, focus group discussion, and questionnaires. The authors identified five types of prayers: diseasecentered; assurance-centered; God-centered; other-centered; and lamentations. According to the authors, the disease-centered prayers were the most commonly used, while the prayers of lamentation were the least used. However, they stated that patients using disease-centered prayers for healing did not always expect to be cured because they feared that healing may not be God's will for them. The majority of disease-centered prayers in chronic illness were focused in cancer patients. The authors discussed the importance of prayers in the clinical setting as coping strategies and disease management and encouraged providers to offer an environment conducive to spiritual expressions.

Sharma et al. (2017) (Appendix A-10) discussed the relationship between religion/spirituality and mental health in US military veterans in a cross-sectional study. The authors stated that they were driven by the recent interest in religion/spirituality as a support in times of difficulty and stress although their review was the first one that focused on military veterans. They mentioned recent studies that linked a higher level of religiosity/spirituality to lower rate of depression, anxiety, substance abuse, and suicidality. A similar study found that religion/spirituality had a protective effect against 
depression and posttraumatic stress disorder. The data gathered for this research paper were from a sample of 3157 military veterans. The Duke University Religion Index (DUREL) was the instrument used to assess religion/spirituality, and based on this tool, three categories were developed: low; moderate; and high religiosity/spirituality. Several tables were used to describe the sample characteristics in terms of sociodemographic, military, psychiatric variables, and the relationship between the different levels of religiosity/spirituality and quality of life. The rates of depression, suicidal thoughts, and alcohol abuse were 34\%, 37\%, and 24\% respectively in the high, moderate, and low religiosity/spirituality group. The odds of having PTSD and alcohol abuse decreased by $70 \%$ and $72 \%$ respectively in the high religiosity/spirituality group compared to the low religiosity/spirituality group. Alcohol abuse increased by $64 \%$ in people with moderate religiosity/spirituality when compared with those with higher religiosity/spirituality. While the authors stressed that the study did not provide any clinical practice guidelines, they suggested further research into religion/spirituality and mental health outcomes.

Oji, Hung, Abbasgholizadeh, Hamilton, Essien and Nwulia (2017) (Appendix A2) explored the role of spirituality in medication adherence in people with chronic illnesses, particularly those affected by HIV and depression. In this review, the terms faith, spirituality, and religion were used interchangeably although they were defined separately. They conducted a systematic review of the literature where 33 articles that fit their criteria were retained. The authors interviewed a convenience sample after obtaining the IRB approval and informed consents from the participants. Also, retrospective chart review was done to assess data such as CD4 level that would confirm patients' adherence to antiretrovirals. The participants were also screened for depression, health behaviors 
like substances abuse, with the SAMISS (substance abuse and mental illness symptoms screener) and spirituality level. The majority of patients with HIV also experienced depression, and the authors reported lower adherence to ART, lower CD4, and by extension lower quality of life. Several tables were used to display their findings. The majority of studies reported a beneficial effect of spirituality on health outcomes. Better adherence was also associated with higher religiosity in one of the studies, $48 \%$ of patients (38/79). There were a few studies that contradicted previous findings and found that belief in God may affect health outcomes negatively as patients may rely more on Him and take a less active part in their health care. Those patients were 4.75 times more likely to be non-compliant with antiretrovirals compared to others without this belief ( $\mathrm{p}=$ 0.032). Patients who also perceived their disease as a punishment from God had negative outcomes such as a faster disease progression within four years.

Ten publications that highlighted the effects of spirituality on health outcomes were included in the review. Six of the articles presented were reviews of the literature, two cross-sectional studies were also depicted, one longitudinal study, and one metaanalysis. Although the authors used different designs and methods to collect data, the common denominator was the positive influence that spirituality had on health outcomes. These reports shared some similarities in terms of their results and clinical implications, while they also had some differences in terms of strengths and limitations.

These reports relate through their results and their clinical implications. They all showed a positive impact of spirituality on health outcomes, whether it's physical or mental. For instance, Koenig (2009) identified that religion was often used as a coping strategy in cases of mental illness and stress. Watlington and Murphy (2006) observed 
that religious involvement was linked to higher social support and a lower rate of depression and PTSD. Aronson et al.(2006) studied the effect of spirituality in the HIV population and noted that spirituality was associated with an increased adherence to antiretroviral treatment and consequently to a longer and better life. Roudsari et al. (2007) identified a lack of data in the literature when it came to the spiritual and religious dimensions of infertility. While Koenig (2009) did not provide any clinical application to spirituality, Ironson et al. (2006) recommended a routine assessment of patients' spirituality and encouraged providers to be more receptive to patients’ spiritual and needs. Watlington and Murphy (2006) focused more on the delivery of a culturally sensitive care. Roudsari et al. (2007) acknowledged the lack of preparation of providers to deal with patients' spiritual needs and encouraged a routine assessment of religious and spiritual needs.

While some authors did not acknowledge any limitations, the majority identified weaknesses in the design or the content of their work. Ironson et al. (2006) considered as a limitation the lack of studies that linked an increase in spirituality/religiosity to an improvement in CD4 and viral load, without involving any healthy behaviors. It is a fact that healthy behaviors like smoking cessation and safer sex play a role in prolonging the life of those living with HIV. Watlington and Murphy (2006) suggested that their study design and the small sample size constituted a limitation. Roudsari et al. (2007) did not mention any limitations, but the fact that they left out male infertility and only addressed this issue in women was a weakness. For Koenig (2009), the absence of clinical implications and the study’s selectivity limited its' scope. Snider and McPhedran (2013) indicated a limited amount of data in the Australian literature about religiosity. Jim et al. 
(2015) considered the exhaustive statistical method as a strength, while the deficiency of data related to the method and the sample size were viewed as weaknesses. De Fazio at al. (2015) did not raise any limitations, but the fact that they based their review on just five studies limited the scope of their findings. Jors et al. (2015) identified the lack of information on prayers that patients make in response to specific diseases, the absence of data about the difference between sick patients’ prayers, and those of healthy individuals as limitations. For Sharma et al. (2017), their cross-sectional study was limited by the design, the sampling, the sample size, and the lack of data about religious affiliations. Similarly, Oji et al. (2017) mentioned the term faith on several occasions but did not reveal any religious affiliations.

Interest in this topic has grown recently and has fueled research to discover the extent of the influence of spirituality in peoples' daily lives. The literature offers a general review of spirituality often associated with the term religion, given that it is difficult to totally separate them and the nature of the topic itself that transcends race, geographic and social boundaries. However, it is clear that there is still a lot to be done to uncover the meaning and the influence of spirituality. This is demonstrated in the literature when authors, for instance, picked a group of people or a subset of a population and tried to determine how spirituality could affect their condition. Since the research and their findings are often selective, the readers only discover spirituality through small pieces of information. Although mental illnesses like depression, anxiety, PTSD, and substances abuse are often discussed, the range of physical diseases mentioned in the literature is often limited to long-term conditions such as cancer and AIDS. Healthy individuals are rarely the subject of these discussions, leaving the impression that healthy 
people are less spiritual or that people tend to become spiritual in times of crisis. A crossanalysis describing these results will be presented in a table in the appendix section.

Next, the summary and conclusions will be presented. 


\section{Summary and Conclusions}

This inquiry started with the purpose of exploring the influence of spirituality on health outcomes. At times, providers focus more on visible issues such as physical pain and neglect less apparent problems that could be at the basis of suffering. Treating the individual as a whole demands that nurses assess and treat the whole person whether the symptom is physical or not. Spirituality is a very fluid concept that has drawn more attention recently, thanks to the impetus to deliver holistic care. Providing holistic care is very difficult without a thorough assessment that takes into account physical, but also spiritual and emotional, needs. According to Barnum (2003), spirituality is a “person’s search for, or expression of, his connection to a greater and meaningful context” (p.1). This definition captured the essence of spirituality and was the one used for the project. Religion refers to an “organized system of beliefs regarding the cause, purpose, and nature of the universe that is shared by a group of people, and the practices, behaviors, worship, and ritual associated with that system”(Burkhardt \& Nagai-Jacobson, 2009, p. 617). Faith is characterized as a deeper and more personal experience than religion that involves a closer relationship with a higher power (O’Brien, 1999). Leininger (1988) defined culture as the sum of values, beliefs, and norms that are learned, shared, and transmitted, and practices of a particular group that guide thinking, decisions, and actions.

Roger's Theory of Unitary Human Beings (1970) was the theoretical framework used to guide this project. This theory focuses on the interactions between individuals and their environment. It was derived from multiple disciplines like religion, psychology, sociology, and astronomy, among others, at a time when the concept of holistic care started to draw more attention within the healthcare community. According to this theory, 
human beings have physical and spiritual dimensions that cannot be separated, and any attempt to treat diseases without considering these two entities will eventually fail.

Several websites were searched including CINAHL and PUBMED over a 20-year period from January 1997 through December 2017, using any combination of the terms spirituality, adults, and health outcomes. Inclusion criteria included evidence-based articles or studies of any design examining the impact of spirituality on health outcomes in adults, including physical and emotional symptoms.

A review of the literature was completed, starting with tentative definitions of the term spirituality and similar concepts such as religion, culture and faith. Several assessment tools like FICA (Puchalski, 1996), HOPE (Anandarajah \& Hight, 2001), SHALOM (Timmins \& Caldeira, 2017), and SPIRIT (Maugans, 1996) were described. In practice, they are used to provide guidance for a rapid assessment. Assessing spirituality has proven to be difficult, given its sensitive nature and providers' reluctance to dive into such a personal matter by fear of being too intrusive. Spirituality, as a universal experience, can be diversely expressed. Several of its expressions were described such as prayers and meditation. Spiritual care was another aspect of holistic care that was addressed during this inquiry. It should be tailored to the patient's needs and followed by the care team. Lane (2005) talked about creativity in delivering spiritual care to explain that patients' response may be different, depending on their preferences. Some may respond better to prayers while others may prefer meditations for instance.

The main purpose of this inquiry was to determine whether spirituality influenced health outcomes. Ten articles and studies that analyzed the impact of spirituality on health outcomes were reviewed and critiqued according to the Polit and Beck framework. 
Several data collection tables were used to analyze the main points of these articles. A cross study analysis was also completed and presented in the appendix section.

Overall, these articles suggested that spirituality had a positive impact on physical and mental health. A wide range of issues were considered in relation to spirituality: physical illnesses such as HIV and cancer or mental issues like depression, anxiety and substance abuse; social and medical issues like domestic violence and infertility with the accompanying array of physical and mental consequences. In the case of HIV, it was suggested that an increase in religiosity/spirituality could improve the viral load and the level of CD4 cells (Aronson et al., 2006). Religion was often used as a coping mechanism and was linked to a higher social support, a lower rate of depression and PTSD, and an increased adherence to treatment in the case of HIV (Oji et al., 2017). Cancer patients with higher religiosity/spirituality experienced peace and felt safer emotionally (Jim et al., 2015). In cases of domestic violence, survivors who were involved in religious activities reported a higher social support and less post-traumatic stress symptoms (Watlington et al., 2006). Infertile women found great comfort in spirituality through prayers, others consult folk healers (Roudsari et al., 2007).

The articles and reviews provided numerous insights into spirituality/religiosity and their influences on daily lives; however, there were also some limitations. Those limitations were primarily noted within individual studies or articles. Some of those weaknesses were identified by the authors such as the design of the study, the sample size (Watlington \& Murphy, 2006) and the lack of data such as limited information on religiosity in Australia (Snider \& McPhedran, 2013). For instance, when certain authors discussed the benefits of spirituality/religiosity on health outcomes, they did not mention 
any religious affiliations (Sharma et al., 2017). The study about infertility in women failed to mention infertility in men, as if this medical issue was particular to women (Roudsari et al., 2007). Overall, these studies were limited by the lack of data about religious affiliations and the role of spirituality on healthy individuals' lives.

In conclusion, this project facilitated the examination of a broader perspective of the term spirituality. It is no longer a narrow concept that only refers to prayers, but a dynamic process of interacting with the environment, oneself, and a higher Being no matter what name is given to this Being by those who believe in Him. This proposal also expanded the perception about the role of spirituality in daily routines. It's not surprising that it is used in diseases like depression, life-threatening conditions such as cancer and HIV, and even social issues like domestic violence.

Next, the recommendations and implications for practice will be presented. 


\section{Recommendations and Implications for Advanced Nursing Practice}

Nurse practitioners (NPs) have the potential to influence policies that will affect individual patients' health and the community well-being at large. As advanced practitioners, their approach to care should be multidimensional. Nurse practitioners have the ability to act as role models to their peers, educate other professionals they collaborate with, advance evidence-based policies, and promote research about the importance of spirituality in patients' care. Although spirituality has been increasingly acknowledged, health care professionals are not consistently convinced of its’ importance in peoples' daily lives and in times of crisis. Increasing awareness about the importance of spiritual assessment, and providing spiritual care, is an opportunity for NPs to influence the way care is administered within their institutions.

Convincing people that spiritual assessment should hold equal importance as pain assessment requires comprehensive training and presentation of evidence-based data. As role models, NPs can start by engaging clinical nurses, who constitute the largest professional group and who are always at the forefront of implementing change. Educating the staff would be the first part of the process of integrating spiritual assessment and spiritual care into the patients' care plan. Ongoing training sessions should focus on the topic of spirituality, assessment, various expressions, and how to provide spiritual care. With the integration of a formal spiritual assessment in the care plan, nurses will be prompted to assess spirituality on every patient admitted. Promoting an environment where spirituality is acknowledged will encourage patients’ free expression of spirituality. 
Providing spiritual care is not solely a nursing duty. Every member of the care team must be involved in this process. Success depends on the participation of the interdisciplinary team such as case managers, social workers, pharmacists, and the medical team. Clinical nurse specialists would be particularly instrumental in educating the staff and the patients about the topic of spirituality and the benefits associated with spiritual care. Case management could connect patients with people in their community willing to guide them spiritually. Licensed providers could contribute by not only educating patients, but also referring patients for spiritual assistance when necessary. These professionals can lobby for spiritual care to become part of the institution's policy, which would support and emphasize its importance.

In order to promote the benefits of spiritual care to the healthcare community, the advanced practice nurse could present the topic in professional journals or meetings within professional associations, conferences, and group discussions and even advocate for the integration of spiritual care into patients' care at the national level. More research needs to be conducted to uncover other aspects of spirituality. One of the weaknesses identified in the literature was the lack of data about religious affiliations. It would be helpful to know whether a particular group of individuals who share, for instance, similar religious beliefs have affinities for specific spiritual expressions when compared to other individuals who hold different beliefs. Another aspect of spirituality that needs to be explored is whether people who describe themselves as religious benefit more from spirituality than others who say that they are not religious.

Another area where spiritual care could be useful is in the opioid crisis. The nation is experiencing a catastrophe caused by the opioid crisis that does not spare 
anybody. Spiritual care could be of great help in those difficult moments to the victims. The deep pain that these individuals endure cannot always be effectively treated with traditional pain medicine. Besides treating their addiction medically, one approach would be to apply spiritual care that would go beneath the surface to find the causes of their suffering. 


\section{References}

Alistair, R. ( May 2016). Spirituality in therapy. 27(4): 22-25.

Anandarajah, G., \& Hight, E. (2001). Spirituality and medical practice: using the HOPE questions as a practical tool for spiritual assessment. American Family Physician, 63, 81-89.

Barnum, B.S. (2003). Spirituality in nursing: From traditional to new age ( $2^{\text {nd }}$ ed.). New York: Springer.

Blaber, M., Jones, J., Willis, D.(2015). Spiritual care: which is the best assessment tool for palliative settings? International Journal Of Palliative Nursing, 21(9), 430438.

Blais, K. K., \& Hayes, J. S. (2011). Professional nursing practice: concepts and perspectives (6th ed.). New Jersey: Pearson Education, Inc.

Bruckental, P., Marino, M.A., Snelling, L. (2016). Complementary and integrative therapies for persistent pain management in older adults. Journal of Gerontological Nursing. 42(12), 40-48.

Burkhardt, M.A., Nagai-Jacobson, M.G.(2009). Spirituality and health. In B.M. Dossey and L. Keegan (Eds.), Holistic nursing: A Handbook for practice (5 $5^{\text {th }}$ ed.)

Chrash, M., Mulich, B., \& Patton, C.M. (2011). The AON role in holistic assessment and integration of spiritual assessment for advanced care planning. Journal of the American Academy of Nurse Practitioners, 23(10),530-536.

Cowling, R. W. (2000). Healing as appreciating wholeness. , 22(3):16-32. 
De Fazio, P., Gaetano, R., Caroleo, M., Cerminara, G., Giannini, F., Jaen Moreno, M. J., Garcia, C. S. (2014). Religion and spirituality in patients with bipolar disorder. International Journal of Psychiatry in Clinical Practice, 19, 234-238

Dossey, L. (1993). Healing words: The power of prayer and the practice of medicine. San Francisco: Harper.

Draper, P. (2012). An Integrative review of spiritual assessment: Implications for nursing management. Journal of Nursing Management, 20, 970-980.

Hodge, D., R. (2013). Implicit Spiritual assessment: An Alternative Approach for Assessing Client Spirituality. Social Work 58(3), 223-230.

Ironson, G., Stuetzle, R., \& Fletcher, M. A. (2006). An Increase in religiousness/spirituality occurs after HIV diagnosis and predicts slower disease progression over 4 years in people with HIV. Society of General Internal Medicine, 5, 62-68.

Jim, H. S., Pustejovsky, J. E., Park, C. L., Danhauer, S. C., Sherman, A. C., Fitchett, G., ... Munoz, A. R. (2015). Religion, spirituality, and physical health in cancer patients: A meta-analysis.

Jors, K., Bussing, A., Hvidt, N. C., \& Baumann, K. (2015). Personal prayer in patients dealing with chronic illness: A review of the research literature. Evidence-based Complementary and Alternative Medecine, 2015, 1-12.

Koenig, H. G. (2009). Research on religion, spirituality, and mental health: a review. The Canadian Journal of Psychiatry, 54, 283-291. 
Lane, M. R. (2005). Creativity and Spirituality in Nursing: Implementing Art in Healing. Holistic Nursing Practice, 19(3), 122-125.

Leininger, M.M. (1988). Leininger’s theory of nursing: Cultural care diversity and universality. Nursing Science Quaterly, 14, 152-160.

Mauk, K.L., \& Schmidt, N. K. (2004). Spiritual care in nursing practice. Philadelphia: Lippincott Williams \& Wilkins.

McClean, S., Bunt, L., \& Daykin, N. (2012).The Healing and Spiritual Properties of Music Therapy at a Cancer Care Center.Journal of Alternative and Complementary Medecine, 18(4), 402-407.

Merriam-Webster Dictionary, n.d

Narayanasamy, A. (2004). Spiritual care. The puzzle of spirituality for nursing: A guide to practical assessment. British Journal of Nursing, 13(19), 1140-1144.

Nurses Code of Ethics (2015).

O’Brien, M.E. (1999). Spirituality in nursing: Standing on Holy Groung. Jones and Bartlet.

O’Brien, M.E. (2008). Spirituality in Nursing ( $3^{\text {rd }}$ ed.): Standing on Holy Ground. Jones and Bartlett; London:2008.

Oji, V. U., Hung, L. C., Abbasgholizadeh, R., Hamilton, F. T., Essien, E. J., \& Nwulia, E. (2017). Spiritual care may impact mental health and medication adherence in HIV+ populations. Research and palliative care, 101-109

Pike, J.(2011). Spirituality in nursing: A systematic review of the literature from 20062010. British Journal of Nursing, 20(12), 743-749. 
Polit, D. F., Beck, C. T. (2017). Essentials of nursing research: Appraising evidence for nursing practice.( $7^{\text {th }}$.ed). Philadelphia. Lippincott Williams \& Wilkins.

Puchalski, C. (1996). The FICA Spiritual History Tool. .

Rogers, M. E. (1970). An Introduction to the Theoretical Basis of Nursing. New York: F.A. Davis Company.

Roudsari, R. L., Allan, H. T., \& Smith, P. A. (2007). Looking at infertility through the lens of religion and spirituality. Human fertility, 10, 141-149.

Sharma, V., Marin, D. B., Koenig, H. K., Feder, A., Iacoviello, B. M., Southwick, S. M., \& Pietrzak, R. H. (2017). Religion, spirituality, and mental health of U.S. military veterans: results from the National Health and Resilience in Veterans study. Journal of affective disorders.

Shelly, J.A., \& Fish, S. (1988). Spiritual care: The nurse's role ( $3^{\text {rd }}$ ed.). Downers Grove, IL: Intervarsity Press.

Snider, A. M., \& McPhedran, S. (2014). Religiosity, Spirituality, mental health, and mental health outcomes in Australia: A systematic literature review. Mental Health, Religion, and Culture, 17(6), 568-581.

Tanyi, R.A. (2002). Towards Clarification of the meaning of Spirituality. Journal of Advanced Nursing, 39(5), 500-509.

Tanyi, R. (2006). Spirituality and family nursing: spiritual assessment and interventions for families. Journal Of Advanced Nursing, 53(3), 287-294.

Timmins, F., Caldeira, S. (2017). Assessing the Spiritual needs of patients. Nursing Standard. 31(29), 47-53. 
Treloar, L. L. (2000). Integration of Spirituality into health care practice by nurse practitioners. Journal of the American Academy of Nurse Practitioners, 12(7), 280-285

US Department of Health and Human Services, Office of Minority Health. (2005). What is cultural competency? Washington, DC: USDHHS

Watlington, C. G., \& Murphy, C. M. (2006). The roles of religion and spirituality among African American survivors of domestic violence. Journal of Clinical Psychology, 62, 837-856 


\section{Appendix A-1}

\section{Table 1}

\begin{tabular}{|c|c|c|}
\hline Aspect of the Report & Critiquing Questions & Detailed Critiquing Guidelines \\
\hline $\begin{array}{l}\text { Title } \\
\text { Personal Prayers in Patients } \\
\text { dealing with Chronic Illness: } \\
\text { A Review of the Research } \\
\text { Literature. } \\
\text { Jors, K., Bussing, A., Hvidt, } \\
\text { N. C., \& Baumann, K. (2015). }\end{array}$ & $\begin{array}{l}\text { Is the title a good one, } \\
\text { succinctly suggesting key } \\
\text { variables and the study } \\
\text { population? }\end{array}$ & $\begin{array}{l}\text { The title suggested that the } \\
\text { key variables that would be } \\
\text { addressed are prayers, as an } \\
\text { expression of spirituality, and } \\
\text { chronically ill people. }\end{array}$ \\
\hline Abstract & $\begin{array}{l}\text { Did the abstract clearly and } \\
\text { concisely summarize the main } \\
\text { features of the report (problem, } \\
\text { methods, results, conclusions)? }\end{array}$ & $\begin{array}{l}\text { The abstract addressed the } \\
\text { problem, the method used, } \\
\text { the results and the } \\
\text { conclusions. }\end{array}$ \\
\hline $\begin{array}{l}\text { Introduction } \\
\text { Statement of the problem }\end{array}$ & $\begin{array}{l}\text { Was the problem stated } \\
\text { unambiguously, and was it easy } \\
\text { to identify? } \\
\text { Is the problem statement build } \\
\text { a persuasive argument for the } \\
\text { new study? } \\
\text { Was there a good match } \\
\text { between the research problem } \\
\text { and the methods used -that is, } \\
\text { was a quantitative approach } \\
\text { appropriate? }\end{array}$ & $\begin{array}{l}\text { The problem was as a lack of } \\
\text { understanding of the reasons } \\
\text { that make people turn to } \\
\text { prayers in time of illness. } \\
\text { The authors built an argument } \\
\text { for this new study as they } \\
\text { began asking specific } \\
\text { questions related to the } \\
\text { problem. That then let the } \\
\text { authors to conduct a } \\
\text { systematic review of the } \\
\text { literature. }\end{array}$ \\
\hline
\end{tabular}




\begin{tabular}{|c|c|c|}
\hline Aspect of the Report & Critiquing Questions & Detailed Critiquing Guidelines \\
\hline $\begin{array}{l}\text { Hypotheses or research } \\
\text { questions }\end{array}$ & $\begin{array}{l}\text { Were research questions } \\
\text { and/or hypotheses explicitly } \\
\text { stated? If not, was their } \\
\text { absence justified? } \\
\text { Were questions and hypotheses } \\
\text { appropriately worded, with } \\
\text { clear specification of key } \\
\text { variables and the study } \\
\text { population? } \\
\text { Were the questions/hypotheses } \\
\text { consistent with existing } \\
\text { knowledge? }\end{array}$ & $\begin{array}{l}\text { The research questions were } \\
\text { explicit, related to the key } \\
\text { variables and consistent with } \\
\text { existing knowledge. They } \\
\text { were formulated as follows: } \\
\text { Why do people turn to } \\
\text { prayers in time of illness? } \\
\text { What are the main topics of } \\
\text { their prayers? How do they } \\
\text { pray? }\end{array}$ \\
\hline Literature review & $\begin{array}{l}\text { Was the literature review up- } \\
\text { to-date and based mainly on } \\
\text { primary sources? } \\
\text { Did the review provide a state- } \\
\text { of-the-art synthesis of evidence } \\
\text { on the problem? } \\
\text { Did the literature review } \\
\text { provide a strong basis for the } \\
\text { new study? }\end{array}$ & $\begin{array}{l}\text { The review was based on } \\
\text { empirical' sources that } \\
\text { focused on prayers and illness } \\
\text { and provided a wide range of } \\
\text { data about the subject. There } \\
\text { were no limitations on the } \\
\text { language, year, design, or } \\
\text { status of the sources. }\end{array}$ \\
\hline $\begin{array}{l}\text { Conceptual/theoretical } \\
\text { framework }\end{array}$ & $\begin{array}{l}\text { Were key concepts adequately } \\
\text { defined conceptually? } \\
\text { Was a conceptual/theoretical } \\
\text { framework articulated-and, if } \\
\text { so, was it appropriate? If not, is } \\
\text { the absence of a framework } \\
\text { justified? } \\
\text { Were the questions/hypotheses } \\
\text { consistent with the framework? }\end{array}$ & $\begin{array}{l}\text { There was no theoretical } \\
\text { framework cited for this } \\
\text { research. }\end{array}$ \\
\hline $\begin{array}{l}\text { Method } \\
\text { Protection of human rights }\end{array}$ & $\begin{array}{l}\text { Were appropriate procedures } \\
\text { used to safe-guard the rights of } \\
\text { study participants? } \\
\text { Was the study externally } \\
\text { reviewed by an IRB/ethics } \\
\text { review board? } \\
\text { Was the study designed to } \\
\text { minimize risks and maximize } \\
\text { benefits to participants? }\end{array}$ & $\begin{array}{l}\text { There were no human } \\
\text { subjects involved directly in } \\
\text { this review of the literature. }\end{array}$ \\
\hline Research design & $\begin{array}{l}\text { Was the most rigorous design } \\
\text { used, given the study purpose? } \\
\text { Were appropriate comparisons } \\
\text { made to enhance } \\
\text { interpretability of the findings? } \\
\text { Was the number of data } \\
\text { collection points appropriate? }\end{array}$ & $\begin{array}{l}\text { The design used was a review } \\
\text { of the literature that included } \\
\text { all types of studies in order to } \\
\text { have a broader perspective on } \\
\text { the subject. }\end{array}$ \\
\hline
\end{tabular}




\begin{tabular}{|c|c|c|}
\hline Aspect of the Report & Critiquing Questions & Detailed Critiquing Guidelines \\
\hline & $\begin{array}{l}\text { Did the design minimize biases } \\
\text { and threats to the internal, } \\
\text { construct, and external validity } \\
\text { of the study (e.g., was blinding } \\
\text { used, was attrition minimized)? }\end{array}$ & \\
\hline Population and sample & $\begin{array}{l}\text { Was the population identified? } \\
\text { Was the sample described in } \\
\text { sufficient detail? } \\
\text { Was the best possible sampling } \\
\text { design used to enhance the } \\
\text { sample's representativeness? } \\
\text { Were sampling biases } \\
\text { minimized? } \\
\text { Was the sample size based on a } \\
\text { power analysis? }\end{array}$ & $\begin{array}{l}\text { The population was identified } \\
\text { through prior studies. The } \\
\text { majority of the participants } \\
\text { were Christian women, } \\
\text { Caucasian or African } \\
\text { American, living in the United } \\
\text { States. Over half of the } \\
\text { respondents were above } 50 \\
\text { years old. The participants } \\
\text { were affected by either HIV, } \\
\text { heart disease, Hepatitis C, } \\
\text { cancer, or sickle cell disease. } \\
\text { There were Muslims } \\
\text { represented in only one study } \\
\text { conducted in Iran. Power } \\
\text { analysis was not a factor in } \\
\text { the sample size. }\end{array}$ \\
\hline $\begin{array}{l}\text { Data collection and } \\
\text { measurement }\end{array}$ & $\begin{array}{l}\text { Were the operational and } \\
\text { conceptual definitions } \\
\text { congruent? } \\
\text { Were key variables measured } \\
\text { using an appropriate method } \\
\text { (e.g., interviews, observations, } \\
\text { and so on)? } \\
\text { Were specific instruments } \\
\text { adequately described and were } \\
\text { they good choices, given the } \\
\text { study population and the } \\
\text { variables being studied? } \\
\text { Did the report provide evidence } \\
\text { that the data collection } \\
\text { methods yielded data that were } \\
\text { reliable, valid and responsive? }\end{array}$ & $\begin{array}{l}\text { Data were collected through } \\
\text { the websites Medline, } \\
\text { PubMed, PsycINFO in } 2013 \\
\text { and 2014, using the words } \\
\text { prayer, illness, pain, chronic, } \\
\text { sickness. A total of } 16 \text { articles } \\
\text { that fit the inclusion criteria } \\
\text { were retained for the final } \\
\text { study. The data collected from } \\
\text { the studies were related to } \\
\text { the design, study questions, } \\
\text { the number of participants, } \\
\text { the sample's demographics. } \\
\text { Other information related to } \\
\text { the prayer habits were } \\
\text { submitted to the reviewers. }\end{array}$ \\
\hline Procedures & $\begin{array}{l}\text { If there was an intervention, } \\
\text { was it adequately described, } \\
\text { and was it rigorously developed } \\
\text { and implemented? Did most } \\
\text { participants allocated to the } \\
\text { intervention group actually } \\
\text { receive it? Was there evidence } \\
\text { of intervention fidelity? } \\
\text { Were data collected in a }\end{array}$ & $\begin{array}{l}\text { There was no intervention } \\
\text { related to this study. }\end{array}$ \\
\hline
\end{tabular}




\begin{tabular}{|c|c|c|}
\hline Aspect of the Report & Critiquing Questions & Detailed Critiquing Guidelines \\
\hline & $\begin{array}{l}\text { manner that minimized bias? } \\
\text { Were the staff who collected } \\
\text { data appropriately trained? }\end{array}$ & \\
\hline Data Analysis & $\begin{array}{l}\text { Were analyses undertaken to } \\
\text { address each research question } \\
\text { or test each hypothesis? } \\
\text { Were appropriate statistical } \\
\text { methods used, given the level } \\
\text { of measurement of the } \\
\text { variables, number of groups } \\
\text { being compared, and } \\
\text { assumptions of the texts? } \\
\text { Was a powerful analytic } \\
\text { method used? (e.g., did the } \\
\text { analysis help to control for } \\
\text { confounding variables)? } \\
\text { Were type I and Type II errors } \\
\text { avoided or minimized? } \\
\text { In intervention studies, was an } \\
\text { intention-to-treat analysis } \\
\text { performed? }\end{array}$ & $\begin{array}{l}\text { Relevant data from each study } \\
\text { were arranged according to } \\
\text { the study design, the study } \\
\text { questions, the number of } \\
\text { participants, diagnosis, and } \\
\text { the way they prayed. The data } \\
\text { were entered into an Excel } \\
\text { table and analyzed by three } \\
\text { reviewers. Disagreements } \\
\text { were resolved by consensus. }\end{array}$ \\
\hline Data Analysis (continued) & $\begin{array}{l}\text { Were problems of missing } \\
\text { values evaluated and } \\
\text { adequately addressed? }\end{array}$ & \\
\hline Findings & $\begin{array}{l}\text { Was information about } \\
\text { statistical significance } \\
\text { presented? Was information } \\
\text { about effect size and precision } \\
\text { of estimates (confidence } \\
\text { intervals) presented? } \\
\text { Were the findings adequately } \\
\text { summarized, with good use of } \\
\text { tables and figures? } \\
\text { Were findings reported in a } \\
\text { manner that facilitates a meta- } \\
\text { analysis, and with sufficient } \\
\text { information needed for EBP? }\end{array}$ & $\begin{array}{l}\text { Five types of prayer were } \\
\text { identified: disease-centered; } \\
\text { assurance-centered; God- } \\
\text { centered; other-centered; and } \\
\text { lamentations prayers. The } \\
\text { findings were presented in } \\
\text { tables where the disease- } \\
\text { centered prayer was the most } \\
\text { common type of prayer used, } \\
\text { while the least common was } \\
\text { the lamentations. Subjects } \\
\text { preferred informal prayers } \\
\text { and were very flexible about } \\
\text { the place of prayer. }\end{array}$ \\
\hline $\begin{array}{l}\text { Discussion } \\
\text { Interpretation of the } \\
\text { findings }\end{array}$ & $\begin{array}{l}\text { Were all major findings } \\
\text { interpreted and discussed } \\
\text { within the context of prior } \\
\text { research and/or the study's } \\
\text { conceptual framework? }\end{array}$ & $\begin{array}{l}\text { The authors discovered that } \\
\text { patients do not always pray } \\
\text { for healing out of fear of not } \\
\text { being heard by God, but } \\
\text { would pray for their pain to }\end{array}$ \\
\hline
\end{tabular}




\begin{tabular}{|c|c|c|}
\hline Aspect of the Report & Critiquing Questions & Detailed Critiquing Guidelines \\
\hline & $\begin{array}{l}\text { Were casual inferences, if any, } \\
\text { justified? } \\
\text { Was the issue of clinical } \\
\text { significance discussed? } \\
\text { Were interpretations well- } \\
\text { founded and consistent with } \\
\text { the study's limitations? } \\
\text { Did the report address the issue } \\
\text { of the generalizability of the } \\
\text { findings? }\end{array}$ & $\begin{array}{l}\text { be relieved. Fewer studies } \\
\text { mentioned lamentations, as it } \\
\text { is perceived by some as } \\
\text { negative to the patient's well- } \\
\text { being. The authors identified } \\
\text { that this study is relevant to } \\
\text { practice since patients turn to } \\
\text { prayers for decisions } \\
\text { regarding health decisions. }\end{array}$ \\
\hline $\begin{array}{l}\text { Implications/ } \\
\text { recommendations }\end{array}$ & $\begin{array}{l}\text { Did the researchers discuss the } \\
\text { implications of the study for } \\
\text { clinical practice or further } \\
\text { research-and were those } \\
\text { implications reasonable and } \\
\text { complete? }\end{array}$ & $\begin{array}{l}\text { The authors recommended } \\
\text { that practitioners use this } \\
\text { knowledge to address } \\
\text { patients' prayer needs in their } \\
\text { care plan. }\end{array}$ \\
\hline $\begin{array}{l}\text { General Issues } \\
\text { Presentation }\end{array}$ & $\begin{array}{l}\text { Was the report well-written, } \\
\text { organized, and sufficiently } \\
\text { detailed for critical analysis? } \\
\text { In intervention studies, was a } \\
\text { CONSORT flowchart provided to } \\
\text { show the flow of participants in } \\
\text { the study? } \\
\text { Was the report written in a } \\
\text { manner that makes the findings } \\
\text { accessible to practicing nurses? }\end{array}$ & $\begin{array}{l}\text { This report was detailed } \\
\text { enough for critical analysis. A } \\
\text { flowchart was developed to } \\
\text { describe the population of } \\
\text { interest. } \\
\text { The report is accessible to } \\
\text { practicing nurses. The authors } \\
\text { specified that the access was } \\
\text { unrestricted to the public. }\end{array}$ \\
\hline Researcher credibility & $\begin{array}{l}\text { Do the researchers' clinical, } \\
\text { substantive, or methodologic } \\
\text { qualifications and experience } \\
\text { enhance confidence in the } \\
\text { findings and their } \\
\text { interpretation? }\end{array}$ & $\begin{array}{l}\text { The authors are faculty } \\
\text { members of several } \\
\text { universities in Europe. Their } \\
\text { qualifications enhance the } \\
\text { value of their findings. }\end{array}$ \\
\hline Summary assessment & $\begin{array}{l}\text { Despite any limitations, do the } \\
\text { study findings appear to be } \\
\text { valid-do you have confidence } \\
\text { in the truth value of the results? } \\
\text { Does the study contribute any } \\
\text { meaningful evidence that can } \\
\text { be used in nursing practice or } \\
\text { that is useful to the nursing } \\
\text { discipline? }\end{array}$ & $\begin{array}{l}\text { They acknowledged that they } \\
\text { did not have all the answers } \\
\text { and that the field is open to } \\
\text { more advanced research. } \\
\text { This literature review can } \\
\text { significantly contribute to } \\
\text { nurses' knowledge base about } \\
\text { the role of prayers in the } \\
\text { patients' daily life and what } \\
\text { they can do to provide an } \\
\text { atmosphere of prayers to } \\
\text { those who practice it. }\end{array}$ \\
\hline
\end{tabular}




\section{Appendix A-2}

Table 2

\begin{tabular}{|c|c|c|}
\hline Aspect of the Report & Critiquing Questions & Detailed Critiquing Guidelines \\
\hline $\begin{array}{l}\text { Title } \\
\text { Spiritual care may impact } \\
\text { mental health and } \\
\text { medication adherence in } \\
\text { HIV + populations } \\
\text { Oji, V.U., Hung, L.C., } \\
\text { Abbasgholizadeh, A., } \\
\text { Essien, E.J., \& Nwulia, } \\
\text { E. (2017). }\end{array}$ & $\begin{array}{l}\text { Is the title a good one, } \\
\text { succinctly suggesting key } \\
\text { variables and the study } \\
\text { population? }\end{array}$ & $\begin{array}{l}\text { The title suggested a two- } \\
\text { pronged approach where } \\
\text { physical and mental health } \\
\text { problems such as depression } \\
\text { were discussed in relation to } \\
\text { spiritual care within } \\
\text { communities affected by HIV. }\end{array}$ \\
\hline Abstract & $\begin{array}{l}\text { Did the abstract clearly and } \\
\text { concisely summarize the main } \\
\text { features of the report (problem, } \\
\text { method s, results, conclusions)? }\end{array}$ & $\begin{array}{l}\text { The abstract summarized the } \\
\text { main points of the article } \\
\text { which were mental and } \\
\text { physical health in people } \\
\text { affected by HIV, primarily } \\
\text { African Americans. It } \\
\text { mentioned the method, which } \\
\text { included a review of the } \\
\text { literature and a retrospective } \\
\text { chart review, the results, and } \\
\text { the conclusions of the report. }\end{array}$ \\
\hline $\begin{array}{l}\text { Introduction } \\
\text { Statement of the problem }\end{array}$ & $\begin{array}{l}\text { Was the problem stated } \\
\text { unambiguously, and was it easy } \\
\text { to identify? } \\
\text { Is the problem statement build } \\
\text { a persuasive argument for the } \\
\text { new study? } \\
\text { Was there a good match } \\
\text { between the research problem } \\
\text { and the methods used -that is, }\end{array}$ & $\begin{array}{l}\text { The problem was identified as } \\
\text { a possible influence of } \\
\text { spiritual care on medication } \\
\text { adherence in people with } \\
\text { chronic illnesses such as } \\
\text { depression and HIV. The } \\
\text { problem statement built the } \\
\text { case for the literature review } \\
\text { since prior data reported both }\end{array}$ \\
\hline
\end{tabular}




\begin{tabular}{|c|c|c|}
\hline Aspect of the Report & Critiquing Questions & Detailed Critiquing Guidelines \\
\hline & $\begin{array}{l}\text { was a quantitative approach } \\
\text { appropriate? }\end{array}$ & $\begin{array}{l}\text { positive and negative impacts } \\
\text { of spirituality on health } \\
\text { outcomes. There was a good } \\
\text { match between the research } \\
\text { problem that explored the } \\
\text { role of spiritual care in } \\
\text { medication adherence and } \\
\text { mental health in people } \\
\text { affected by HIV. A } \\
\text { quantitative approach was } \\
\text { more appropriate because the } \\
\text { literature review included } \\
\text { primarily quantitative studies. }\end{array}$ \\
\hline $\begin{array}{l}\text { Hypotheses or research } \\
\text { questions }\end{array}$ & $\begin{array}{l}\text { Were research questions } \\
\text { and/or hypotheses explicitly } \\
\text { stated? If not, was their } \\
\text { absence justified? } \\
\text { Were questions and hypotheses } \\
\text { appropriately worded, with } \\
\text { clear specification of key } \\
\text { variables and the study } \\
\text { population? } \\
\text { Were the questions/hypotheses } \\
\text { consistent with existing } \\
\text { knowledge? }\end{array}$ & $\begin{array}{l}\text { The research questions were } \\
\text { not explicitly stated. The } \\
\text { authors identified the } \\
\text { objectives as the exploration } \\
\text { of current data about } \\
\text { spirituality and medication } \\
\text { adherence in people with } \\
\text { depression and HIV and } \\
\text { health outcomes. } \\
\text { Their hypotheses were } \\
\text { consistent with the } \\
\text { knowledge that spiritual care } \\
\text { can have positive or negative } \\
\text { impacts. }\end{array}$ \\
\hline Literature review & $\begin{array}{l}\text { Was the literature review up- } \\
\text { to-date and based mainly on } \\
\text { primary sources? } \\
\text { Did the review provide a state- } \\
\text { of-the-art synthesis of evidence } \\
\text { on the problem? } \\
\text { Did the literature review } \\
\text { provide a strong basis for the } \\
\text { new study? }\end{array}$ & $\begin{array}{l}\text { An extensive review of the } \\
\text { literature was undertaken to } \\
\text { look for data that addressed } \\
\text { the impact of faith and } \\
\text { spirituality on medication } \\
\text { adherence among patients } \\
\text { undergoing long-term } \\
\text { treatment. The authors } \\
\text { reviewed articles from } 1986 \\
\text { to } 2015 \text { using key words such } \\
\text { as impact or influence and } \\
\text { spirituality, or faith, or } \\
\text { religion, on HIV or AIDS or } \\
\text { depression and medication. } \\
\text { Following the inclusion } \\
\text { criteria that were medication } \\
\text { adherence studies related to } \\
\text { HIV +/AIDS and/or depression. } \\
\text { They reviewed a total of } 48\end{array}$ \\
\hline
\end{tabular}




\begin{tabular}{|c|c|c|}
\hline Aspect of the Report & Critiquing Questions & Detailed Critiquing Guidelines \\
\hline & & $\begin{array}{l}\text { articles, then narrowed to } 33 \\
\text { studies that were directly } \\
\text { related to their inclusion } \\
\text { criteria regardless of the } \\
\text { design. }\end{array}$ \\
\hline $\begin{array}{l}\text { Conceptual/theoretical } \\
\text { framework }\end{array}$ & $\begin{array}{l}\text { Were key concepts adequately } \\
\text { defined conceptually? } \\
\text { Was a conceptual/theoretical } \\
\text { framework articulated-and, if } \\
\text { so, was it appropriate? If not, is } \\
\text { the absence of a framework } \\
\text { justified? } \\
\text { Were the questions/hypotheses } \\
\text { consistent with the framework? }\end{array}$ & $\begin{array}{l}\text { The concepts of faith, religion, } \\
\text { and spirituality were defined } \\
\text { in the introduction. The } \\
\text { authors cited a conceptual } \\
\text { illustration from the literature } \\
\text { that included the terms } \\
\text { spirituality, adherence, and } \\
\text { health but did not further } \\
\text { develop it. }\end{array}$ \\
\hline $\begin{array}{l}\text { Method } \\
\text { Protection of human rights }\end{array}$ & $\begin{array}{l}\text { Were appropriate procedures } \\
\text { used to safe-guard the rights of } \\
\text { study participants? } \\
\text { Was the study externally } \\
\text { reviewed by an IRB/ethics } \\
\text { review board? } \\
\text { Was the study designed to } \\
\text { minimize risks and maximize } \\
\text { benefits to participants? }\end{array}$ & $\begin{array}{l}\text { The approval of the } \\
\text { Institutional Review Board } \\
\text { was granted for the } \\
\text { completion of the study. } \\
\text { Informed consent was } \\
\text { obtained from study } \\
\text { participants. The authors used } \\
\text { a mixed-methods approach to } \\
\text { explore the effects of } \\
\text { spirituality on chronic } \\
\text { conditions, particularly } \\
\text { depression and HIV. }\end{array}$ \\
\hline $\begin{array}{l}\text { Data collection and } \\
\text { measurement }\end{array}$ & $\begin{array}{l}\text { Were the operational and } \\
\text { conceptual definitions } \\
\text { congruent? } \\
\text { Were key variables measured } \\
\text { using an appropriate method } \\
\text { (e.g., interviews, observations, } \\
\text { and so on)? } \\
\text { Were specific instruments } \\
\text { adequately described and were } \\
\text { they good choices, given the } \\
\text { study population and the } \\
\text { variables being studied? } \\
\text { Did the report provide evidence } \\
\text { that the data collection } \\
\text { methods yielded data that were } \\
\text { reliable, valid and responsive? }\end{array}$ & $\begin{array}{l}\text { The data were collected by } \\
\text { the staff clinic using different } \\
\text { scales to assess mental health } \\
\text { and substance abuse. One of } \\
\text { the tools was the SAMISS } \\
\text { (Substance Abuse and Mental } \\
\text { Illness Symptoms Screener) } \\
\text { that comprises } 16 \text { questions; } \\
\text { among them were questions } \\
\text { about their drinking habits, } \\
\text { symptoms of depression } \\
\text { lasting two weeks or more, } \\
\text { and illegal drug use. Another } \\
\text { tool used was the CMR or } \\
\text { Comprehensive Medication } \\
\text { Review where patients were } \\
\text { asked about medication } \\
\text { management and medication- } \\
\text { related problems. A history of } \\
\text { contact with a spiritual } \\
\text { advisor was also included in }\end{array}$ \\
\hline
\end{tabular}




\begin{tabular}{|c|c|c|}
\hline Aspect of the Report & Critiquing Questions & Detailed Critiquing Guidelines \\
\hline & & $\begin{array}{l}\text { the patents' charts was part of } \\
\text { the data gathered. }\end{array}$ \\
\hline Procedures & $\begin{array}{l}\text { If there was an intervention, } \\
\text { was it adequately described, } \\
\text { and was it rigorously developed } \\
\text { and implemented? Did most } \\
\text { participants allocated to the } \\
\text { intervention group actually } \\
\text { receive it? Was there evidence } \\
\text { of intervention fidelity? } \\
\text { Were data collected in a } \\
\text { manner that minimized bias? } \\
\text { Were the staff who collected } \\
\text { data appropriately trained? }\end{array}$ & $\begin{array}{l}\text { The data collection was } \\
\text { appropriate. Patients' consent } \\
\text { was obtained for a } \\
\text { retrospective review of their } \\
\text { charts. There was no } \\
\text { intervention implemented in } \\
\text { this study. }\end{array}$ \\
\hline Data Analysis & $\begin{array}{l}\text { Were analyses undertaken to } \\
\text { address each research question } \\
\text { or test each hypothesis? } \\
\text { Were appropriate statistical } \\
\text { methods used, given the level } \\
\text { of measurement of the } \\
\text { variables, number of groups } \\
\text { being compared, and } \\
\text { assumptions of the texts? } \\
\text { Was a powerful analytic } \\
\text { method used? (e.g., did the } \\
\text { analysis help to control for } \\
\text { confounding variables)? } \\
\text { Were type I and Type II errors } \\
\text { avoided or minimized? } \\
\text { In intervention studies, was an } \\
\text { intention-to-treat analysis } \\
\text { performed? }\end{array}$ & $\begin{array}{l}\text { The statistical method used to } \\
\text { analyze the findings was the } \\
\text { STATA, version } 12 \text {. } \\
\text { A group of patients with HIV } \\
\text { and treated for depression } \\
\text { was compared to another } \\
\text { group that had not received } \\
\text { treatment. The authors found } \\
\text { that those who were treated } \\
\text { for depression were more } \\
\text { likely to adhere to the ART } \\
\text { regimen. }\end{array}$ \\
\hline Procedures & $\begin{array}{l}\text { If there was an intervention, } \\
\text { was it adequately described, } \\
\text { and was it rigorously developed } \\
\text { and implemented? Did most } \\
\text { participants allocated to the } \\
\text { intervention group actually } \\
\text { receive it? Was there evidence } \\
\text { of intervention fidelity? } \\
\text { Were data collected in a } \\
\text { manner that minimized bias? } \\
\text { Were the staff who collected } \\
\text { data appropriately trained? }\end{array}$ & $\begin{array}{l}\text { The data collection was } \\
\text { appropriate. Patients' consent } \\
\text { was obtained for a } \\
\text { retrospective review of their } \\
\text { charts. There was no } \\
\text { intervention implemented in } \\
\text { this study. }\end{array}$ \\
\hline
\end{tabular}




\begin{tabular}{|c|c|c|}
\hline Aspect of the Report & Critiquing Questions & Detailed Critiquing Guidelines \\
\hline Data Analysis & $\begin{array}{l}\text { Were analyses undertaken to } \\
\text { address each research question } \\
\text { or test each hypothesis? } \\
\text { Were appropriate statistical } \\
\text { methods used, given the level } \\
\text { of measurement of the } \\
\text { variables, number of groups } \\
\text { being compared, and } \\
\text { assumptions of the texts? } \\
\text { Was a powerful analytic } \\
\text { method used? (e.g., did the } \\
\text { analysis help to control for } \\
\text { confounding variables)? } \\
\text { Were type I and Type II errors } \\
\text { avoided or minimized? } \\
\text { In intervention studies, was an } \\
\text { intention-to-treat analysis } \\
\text { performed? } \\
\text { Were problems of missing } \\
\text { values evaluated and } \\
\text { adequately addressed? }\end{array}$ & $\begin{array}{l}\text { The statistical method used to } \\
\text { analyze the findings was the } \\
\text { STATA, version } 12 \text {. } \\
\text { A group of patients with HIV } \\
\text { and treated for depression } \\
\text { was compared to another } \\
\text { group that had not received } \\
\text { treatment. The authors found } \\
\text { that those who were treated } \\
\text { for depression were more } \\
\text { likely to adhere to the ART } \\
\text { regimen. } \\
\text { The authors did not address } \\
\text { the issue of missing values. }\end{array}$ \\
\hline Findings & $\begin{array}{l}\text { Was information about } \\
\text { statistical significance } \\
\text { presented? Was information } \\
\text { about effect size and precision } \\
\text { of estimates (confidence } \\
\text { intervals) presented? } \\
\text { Were the findings adequately } \\
\text { summarized, with good use of } \\
\text { tables and figures? } \\
\text { Were findings reported in a } \\
\text { manner that facilitates a meta- } \\
\text { analysis, and with sufficient } \\
\text { information needed for EBP? }\end{array}$ & $\begin{array}{l}\text { Although they used statistical } \\
\text { methods to analyze data, the } \\
\text { authors did not focus on the } \\
\text { statistics. They summarized } \\
\text { results in tables and provided } \\
\text { facts in support of the positive } \\
\text { impact of spiritual care on } \\
\text { depression level. They also } \\
\text { mentioned that many women } \\
\text { acknowledged that spirituality } \\
\text { and belief in God, helped } \\
\text { them adhere to treatment. } \\
\text { Poor adherence was linked to } \\
\text { lower religious beliefs scores. } \\
\text { The authors also discussed } \\
\text { prior studies that touched on } \\
\text { the negative impacts of } \\
\text { religion by pointing out that } \\
\text { patients who relied solely on } \\
\text { God for healing while } \\
\text { minimizing their own role in } \\
\text { the healing process may } \\
\text { refuse to comply with their } \\
\text { ART. Their findings should be } \\
\text { considered for EBP. }\end{array}$ \\
\hline
\end{tabular}




\begin{tabular}{|c|c|c|}
\hline Aspect of the Report & Critiquing Questions & Detailed Critiquing Guidelines \\
\hline $\begin{array}{l}\text { General Issues } \\
\text { Presentation }\end{array}$ & $\begin{array}{l}\text { Was the report written in a } \\
\text { manner that makes the findings } \\
\text { accessible to practicing nurses? }\end{array}$ & $\begin{array}{l}\text { This article was presented in a } \\
\text { clear manner and easy to } \\
\text { read. The data are also } \\
\text { accessible to nurses. }\end{array}$ \\
\hline Researcher credibility & $\begin{array}{l}\text { Do the researchers' clinical, } \\
\text { substantive, or methodologic } \\
\text { qualifications and experience } \\
\text { enhance confidence in the } \\
\text { findings and their } \\
\text { interpretation? }\end{array}$ & $\begin{array}{l}\text { The authors were a group of } \\
\text { medical professionals with } \\
\text { credentials in research. The } \\
\text { fact that their work was } \\
\text { supported by the National } \\
\text { Institutes of Mental Health } \\
\text { and the National Institute of } \\
\text { Health enhanced their } \\
\text { credibility. }\end{array}$ \\
\hline Summary assessment & $\begin{array}{l}\text { Despite any limitations, do the } \\
\text { study findings appear to be } \\
\text { valid-do you have confidence } \\
\text { in the truth value of the results? } \\
\text { Does the study contribute any } \\
\text { meaningful evidence that can } \\
\text { be used in nursing practice or } \\
\text { that is useful to the nursing } \\
\text { discipline? }\end{array}$ & $\begin{array}{l}\text { The results were credible and } \\
\text { the findings can be applied to } \\
\text { nursing care to address } \\
\text { patients' needs in a } \\
\text { comprehensive manner. }\end{array}$ \\
\hline $\begin{array}{l}\text { Discussion } \\
\text { Interpretation of the } \\
\text { findings }\end{array}$ & $\begin{array}{l}\text { Were all major findings } \\
\text { interpreted and discussed } \\
\text { within the context of prior } \\
\text { research and/or the study's } \\
\text { conceptual framework? } \\
\text { Were casual inferences, if any, } \\
\text { justified? } \\
\text { Was the issue of clinical } \\
\text { significance discussed? } \\
\text { Were interpretations well- } \\
\text { founded and consistent with } \\
\text { the study's limitations? } \\
\text { Did the report address the issue } \\
\text { of the generalizability of the } \\
\text { findings? }\end{array}$ & $\begin{array}{l}\text { The authors, referring to their } \\
\text { sources, stated that } \\
\text { spirituality was important to } \\
\text { medication adherence in the } \\
\text { majority of studies. They } \\
\text { noted a few studies where } \\
\text { individuals who had faith in } \\
\text { God were passive and } \\
\text { resistant to therapies. Most } \\
\text { studies discussed adherence } \\
\text { to treatment in the HIV } \\
\text { population while fewer } \\
\text { examined depression and } \\
\text { chronic mental illness. While } \\
\text { discussing their findings, the } \\
\text { authors indicated that African } \\
\text { American were } \\
\text { disproportionately affected by } \\
\text { HIV/AIDS and that other } \\
\text { minority groups were more } \\
\text { dependent on spirituality than } \\
\text { Whites. }\end{array}$ \\
\hline Implications/ & Did the researchers discuss the & The authors recommended an \\
\hline
\end{tabular}




\begin{tabular}{|l|l|l|}
\hline Aspect of the Report & Critiquing Questions & Detailed Critiquing Guidelines \\
\hline recommendations & $\begin{array}{l}\text { implications of the study for } \\
\text { clinical practice or further } \\
\text { research-and were those } \\
\text { implications reasonable and } \\
\text { complete? }\end{array}$ & $\begin{array}{l}\text { assessment of spiritual and } \\
\text { religious beliefs in HIV positive } \\
\text { individuals. They encouraged } \\
\text { screening and treatment of } \\
\text { depression in this population } \\
\text { in order to improve health } \\
\text { outcomes. They suggested } \\
\text { that more research was } \\
\text { needed to study the } \\
\text { importance of spirituality in } \\
\text { dealing with mental health } \\
\text { and medication adherence in } \\
\text { chronic diseases. }\end{array}$ \\
\hline
\end{tabular}

Appendix A-3

Table 3

\begin{tabular}{|c|c|c|}
\hline Aspect of the Report & Critiquing Questions & Detailed Critiquing Guidelines \\
\hline $\begin{array}{l}\text { Title } \\
\text { Religion, Spirituality, and } \\
\text { Physical Health in Cancer } \\
\text { Patients: A Meta-Analysis. } \\
\text { Jim, S.L., Pustejovsky, } \\
\text { J.E., Park, L.C., Danhauer, } \\
\text { S.C., Sherman, A.C., } \\
\text { Fitchett, .G.,..., Salsman, } \\
\text { J.M.(2015). }\end{array}$ & $\begin{array}{l}\text { Is the title a good one, } \\
\text { succinctly suggesting key } \\
\text { variables and the study } \\
\text { population? }\end{array}$ & $\begin{array}{l}\text { The title was a good one } \\
\text { because it summarized the main } \\
\text { points that would be developed. } \\
\text { Key variables included } \\
\text { spirituality, religion, cancer } \\
\text { patients, quality of life and } \\
\text { health outcomes. }\end{array}$ \\
\hline Abstract & $\begin{array}{l}\text { Did the abstract clearly and } \\
\text { concisely summarize the } \\
\text { main features of the report } \\
\text { (problem, methods, results, } \\
\text { conclusions)? }\end{array}$ & $\begin{array}{l}\text { The abstract summarized the } \\
\text { main features of the article and } \\
\text { concluded by acknowledging the } \\
\text { importance of attending to } \\
\text { patients' religious and spiritual } \\
\text { needs. }\end{array}$ \\
\hline $\begin{array}{l}\text { Introduction } \\
\text { Statement of the problem }\end{array}$ & $\begin{array}{l}\text { Was the problem stated } \\
\text { unambiguously, and was it } \\
\text { easy to identify? } \\
\text { Is the problem statement } \\
\text { build a persuasive argument } \\
\text { for the new study? } \\
\text { Was there a good match } \\
\text { between the research } \\
\text { problem and the methods } \\
\text { used -that is, was a } \\
\text { quantitative approach } \\
\text { appropriate? }\end{array}$ & $\begin{array}{l}\text { The authors did not make any } \\
\text { distinction between religion and } \\
\text { spirituality. Although they } \\
\text { provided a definition for each, } \\
\text { they did not separate these two } \\
\text { concepts when they explained } \\
\text { their effects on health } \\
\text { outcomes. }\end{array}$ \\
\hline
\end{tabular}




\begin{tabular}{|c|c|c|}
\hline Aspect of the Report & Critiquing Questions & Detailed Critiquing Guidelines \\
\hline $\begin{array}{l}\text { Hypotheses or research } \\
\text { questions }\end{array}$ & $\begin{array}{l}\text { Were research questions } \\
\text { and/or hypotheses explicitly } \\
\text { stated? If not, was their } \\
\text { absence justified? } \\
\text { Were questions and } \\
\text { hypotheses appropriately } \\
\text { worded, with clear } \\
\text { specification of key variables } \\
\text { and the study population? } \\
\text { Were the } \\
\text { questions/hypotheses } \\
\text { consistent with existing } \\
\text { knowledge? }\end{array}$ & $\begin{array}{l}\text { The research questions were not } \\
\text { explicitly stated, but the writers } \\
\text { hypothesized that religion and } \\
\text { spirituality had positive effects } \\
\text { on cancer patients. They } \\
\text { mentioned other studies that } \\
\text { talked about the influence other } \\
\text { variables such as age and the } \\
\text { type of cancer may have on } \\
\text { patients' outcomes. }\end{array}$ \\
\hline Literature review & $\begin{array}{l}\text { Was the literature review } \\
\text { up-to-date and based } \\
\text { mainly on primary sources? } \\
\text { Did the review provide a } \\
\text { state-of-the-art synthesis of } \\
\text { evidence on the problem? } \\
\text { Did the literature review } \\
\text { provide a strong basis for } \\
\text { the new study? }\end{array}$ & $\begin{array}{l}\text { The sources consisted of original } \\
\text { articles, starting with the earliest } \\
\text { non-dated publications on the } \\
\text { subject through December 20, } \\
2013 \text {. Authors of some original } \\
\text { sources were contacted in order } \\
\text { to provide additional } \\
\text { information data were deemed } \\
\text { incomplete. The inclusion } \\
\text { criteria included adults of at } \\
\text { least } 18 \text { years old with a current } \\
\text { or past diagnosis of cancer, or } \\
\text { being treated for cancer, studies } \\
\text { that assessed a variable of } \\
\text { religion/ spirituality, those that } \\
\text { assessed a physical, mental, or } \\
\text { social health variable, and those } \\
\text { that reported an effect size } \\
\text { measuring the association } \\
\text { between religion/spirituality and } \\
\text { health. Some data were } \\
\text { gathered from small } \\
\text { convenience samples. }\end{array}$ \\
\hline $\begin{array}{l}\text { Conceptual/theoretical } \\
\text { framework }\end{array}$ & $\begin{array}{l}\text { Were key concepts } \\
\text { adequately defined } \\
\text { conceptually? } \\
\text { Was a } \\
\text { conceptual/theoretical } \\
\text { framework articulated- } \\
\text { and, if so, was it } \\
\text { appropriate? If not, is the } \\
\text { absence of a framework } \\
\text { justified? } \\
\text { Were the }\end{array}$ & $\begin{array}{l}\text { There was no clear theoretical } \\
\text { framework guiding this research. }\end{array}$ \\
\hline
\end{tabular}




\begin{tabular}{|c|c|c|}
\hline Aspect of the Report & Critiquing Questions & Detailed Critiquing Guidelines \\
\hline & $\begin{array}{l}\text { questions/hypotheses } \\
\text { consistent with the } \\
\text { framework? }\end{array}$ & \\
\hline $\begin{array}{l}\text { Method } \\
\text { Protection of human rights }\end{array}$ & $\begin{array}{l}\text { Were appropriate } \\
\text { procedures used to safe- } \\
\text { guard the rights of study } \\
\text { participants? } \\
\text { Was the study externally } \\
\text { reviewed by an IRB/ethics } \\
\text { review board? } \\
\text { Was the study designed to } \\
\text { minimize risks and maximize } \\
\text { benefits to participants? }\end{array}$ & $\begin{array}{l}\text { There were no human subjects } \\
\text { involved in this meta-analysis. }\end{array}$ \\
\hline Research design & $\begin{array}{l}\text { Was the most rigorous } \\
\text { design used, given the study } \\
\text { purpose? } \\
\text { Were appropriate } \\
\text { comparisons made to } \\
\text { enhance interpretability of } \\
\text { the findings? } \\
\text { Was the number of data } \\
\text { collection points } \\
\text { appropriate? } \\
\text { Did the design minimize } \\
\text { biases and threats to the } \\
\text { internal, construct, and } \\
\text { external validity of the study } \\
\text { (e.g., was blinding used, was } \\
\text { attrition minimized)? }\end{array}$ & $\begin{array}{l}\text { Meta-analyses were used to } \\
\text { describe quantitatively the } \\
\text { relationship between } \\
\text { religion/spirituality and physical } \\
\text { health outcomes. }\end{array}$ \\
\hline Population and sample & $\begin{array}{l}\text { Was the population } \\
\text { identified? Was the sample } \\
\text { described in sufficient } \\
\text { detail? } \\
\text { Was the best possible } \\
\text { sampling design used to } \\
\text { enhance the sample's } \\
\text { representativeness? Were } \\
\text { sampling biases minimized? } \\
\text { Was the sample size based } \\
\text { on a power analysis? }\end{array}$ & $\begin{array}{l}\text { The population was identified as } \\
\text { adults }>18 \text { years old with } \\
\text { current or past history of cancer. } \\
\text { Other details were the type of } \\
\text { cancer, the disease stage, and } \\
\text { the prognosis. A total of more } \\
\text { than } 32,000 \text { patients whose } \\
\text { profile fit the criteria } \\
\text { participated in the studies. }\end{array}$ \\
\hline
\end{tabular}




\begin{tabular}{|c|c|c|}
\hline Aspect of the Report & Critiquing Questions & Detailed Critiquing Guidelines \\
\hline $\begin{array}{l}\text { Data collection and } \\
\text { measurement }\end{array}$ & $\begin{array}{l}\text { Were the operational and } \\
\text { conceptual definitions } \\
\text { congruent? } \\
\text { Were key variables } \\
\text { measured using an } \\
\text { appropriate method (e.g., } \\
\text { interviews, observations, } \\
\text { and so on)? } \\
\text { Were specific instruments } \\
\text { adequately described and } \\
\text { were they good choices, } \\
\text { given the study population } \\
\text { and the variables being } \\
\text { studied? } \\
\text { Did the report provide } \\
\text { evidence that the data } \\
\text { collection methods yielded } \\
\text { data that were reliable, valid } \\
\text { and responsive? }\end{array}$ & $\begin{array}{l}\text { The concepts religion and } \\
\text { spirituality were defined in } \\
\text { relation to their affective, } \\
\text { behavioral, and cognitive } \\
\text { dimensions. This meta-analysis } \\
\text { used studies that focused on } \\
\text { measurement of } \\
\text { religion/spirituality and physical } \\
\text { health. Religion/spirituality were } \\
\text { measured within four } \\
\text { dimensions: affective; } \\
\text { behavioral; cognitive, and } \\
\text { another dimension called } \\
\text { "other" described as measures } \\
\text { that could not be classified } \\
\text { easily, but resulted in better } \\
\text { physical health and well-being. } \\
\text { The outcomes measures were } \\
\text { grouped into physical, social, or } \\
\text { mental. Validation studies were } \\
\text { included if they fit the criteria. } \\
\text { Demographic and clinical } \\
\text { characteristics were coded in } \\
\text { order to have a better } \\
\text { understanding of the } \\
\text { relationship between } \\
\text { religion/spirituality and health } \\
\text { variables. }\end{array}$ \\
\hline Procedures & $\begin{array}{l}\text { If there was an intervention, } \\
\text { was it adequately described, } \\
\text { and was it rigorously } \\
\text { developed and } \\
\text { implemented? Did most } \\
\text { participants allocated to the } \\
\text { intervention group actually } \\
\text { receive it? Was there } \\
\text { evidence of intervention } \\
\text { fidelity? } \\
\text { Were data collected in a } \\
\text { manner that minimized } \\
\text { bias? Were the staff who } \\
\text { collected data appropriately } \\
\text { trained? }\end{array}$ & $\begin{array}{l}\text { Articles' abstracts were } \\
\text { reviewed by rater pairs to } \\
\text { determine those that met the } \\
\text { inclusion criteria and were } \\
\text { appropriate for a full review. } \\
\text { Studies that fit the inclusion } \\
\text { criteria provided a basis for } \\
\text { measuring religion/spirituality } \\
\text { and health outcomes based on a } \\
\text { common sampling. Outcomes } \\
\text { were classified into categories of } \\
\text { physical, social, mental, or other. } \\
\text { Four rater pairs analyzed the } \\
\text { studies and entered data } \\
\text { deemed relevant. }\end{array}$ \\
\hline
\end{tabular}




\begin{tabular}{|c|c|c|}
\hline Aspect of the Report & Critiquing Questions & Detailed Critiquing Guidelines \\
\hline Data Analysis & $\begin{array}{l}\text { Were analyses undertaken } \\
\text { to address each research } \\
\text { question or test each } \\
\text { hypothesis? } \\
\text { Were appropriate statistical } \\
\text { methods used, given the } \\
\text { level of measurement of the } \\
\text { variables, number of groups } \\
\text { being compared, and } \\
\text { assumptions of the texts? } \\
\text { Was a powerful analytic } \\
\text { method used? (e.g., did the } \\
\text { analysis help to control for } \\
\text { confounding variables)? } \\
\text { Were type I and Type II } \\
\text { errors avoided or } \\
\text { minimized? } \\
\text { In intervention studies, was } \\
\text { an intention-to-treat } \\
\text { analysis performed? } \\
\text { Were problems of missing } \\
\text { values evaluated and } \\
\text { adequately addressed? }\end{array}$ & $\begin{array}{l}\text { A generalized estimating } \\
\text { equation (GEE) estimation was } \\
\text { used to determine the average } \\
\text { effects sizes and meta- } \\
\text { regressions, allowing for a better } \\
\text { analysis of the relationship } \\
\text { between different variables. } \\
\text { The statistical method used was } \\
\text { the Pearson's correlation } \\
\text { measure. } \\
\text { Three types of effect size } \\
\text { statistics were used to measure } \\
\text { the correlation between } \\
\text { spirituality/religion and health } \\
\text { outcome. The writers did not } \\
\text { adequately describe their } \\
\text { statistical methods and did not } \\
\text { address error avoidance or } \\
\text { intention to treat analysis. } \\
\text { If the data were insufficient, the } \\
\text { authors attempted to reach the } \\
\text { authors. }\end{array}$ \\
\hline $\begin{array}{l}\text { Discussion } \\
\text { Interpretation of the findings }\end{array}$ & $\begin{array}{l}\text { Were all major findings } \\
\text { interpreted and discussed } \\
\text { within the context of prior } \\
\text { research and/or the study's } \\
\text { conceptual framework? } \\
\text { Were casual inferences, if } \\
\text { any, justified? } \\
\text { Was the issue of clinical } \\
\text { significance discussed? } \\
\text { Were interpretations well- } \\
\text { founded and consistent with } \\
\text { the study's limitations? } \\
\text { Did the report address the } \\
\text { issue of the generalizability } \\
\text { of the findings? }\end{array}$ & $\begin{array}{l}\text { This meta-analysis found data } \\
\text { consistent with a strong } \\
\text { association between } \\
\text { religion/spirituality and physical } \\
\text { health although previous studies } \\
\text { presented mixed results. The } \\
\text { affective dimension of } \\
\text { religion/spirituality was the } \\
\text { variable most highly associated } \\
\text { with physical health. } \\
\text { The generalizability of the } \\
\text { findings was addressed when } \\
\text { the authors stated that the } \\
\text { positive influence of } \\
\text { spirituality/religion on physical } \\
\text { health was not particular to a } \\
\text { specific socio-demographic or } \\
\text { clinical group. }\end{array}$ \\
\hline
\end{tabular}




\begin{tabular}{|c|c|c|}
\hline Aspect of the Report & Critiquing Questions & Detailed Critiquing Guidelines \\
\hline $\begin{array}{l}\text { Implications/ } \\
\text { recommendations }\end{array}$ & $\begin{array}{l}\text { Did the researchers discuss } \\
\text { the implications of the study } \\
\text { for clinical practice or } \\
\text { further research-and were } \\
\text { those implications } \\
\text { reasonable and complete? }\end{array}$ & $\begin{array}{l}\text { Previous research on affect and } \\
\text { symptom reporting focused on } \\
\text { positive mood rather than } \\
\text { specific emotions that translate } \\
\text { spiritual well-being such as a } \\
\text { sense of connection, meaning, } \\
\text { or purpose. The authors } \\
\text { encouraged a culturally sensitive } \\
\text { environment of care where } \\
\text { patients' spiritual needs are } \\
\text { taken into account. They also } \\
\text { acknowledged the need to } \\
\text { provide spiritual care along the } \\
\text { continuum of cancer stages. }\end{array}$ \\
\hline $\begin{array}{l}\text { General Issues } \\
\text { Presentation }\end{array}$ & $\begin{array}{l}\text { Was the report well-written, } \\
\text { organized, and sufficiently } \\
\text { detailed for critical analysis? } \\
\text { In intervention studies, was } \\
\text { a CONSORT flowchart } \\
\text { provided to show the flow } \\
\text { of participants in the study? }\end{array}$ & $\begin{array}{l}\text { This article was well-written and } \\
\text { organized, but some details that } \\
\text { would explain the statistical } \\
\text { methods adopted were missing. } \\
\text { A flowchart was used to } \\
\text { describe the samples studied for } \\
\text { this meta-analysis. }\end{array}$ \\
\hline Researcher credibility & $\begin{array}{l}\text { Do the researchers' clinical, } \\
\text { substantive, or } \\
\text { methodologic qualifications } \\
\text { and experience enhance } \\
\text { confidence in the findings } \\
\text { and their interpretation? }\end{array}$ & $\begin{array}{l}\text { The report was written by a } \\
\text { group of professionals with at } \\
\text { least a master's degree who held } \\
\text { positions in highly regarded } \\
\text { organizations throughout the } \\
\text { country in different disciplines } \\
\text { such as religion, social services. } \\
\text { It can be inferred that the report } \\
\text { is credible because it went } \\
\text { through rigorous reviews before } \\
\text { being published. }\end{array}$ \\
\hline Summary assessment & $\begin{array}{l}\text { Despite any limitations, do } \\
\text { the study findings appear to } \\
\text { be valid-do you have } \\
\text { confidence in the truth } \\
\text { value of the results? } \\
\text { Does the study contribute } \\
\text { any meaningful evidence } \\
\text { that can be used in nursing } \\
\text { practice or that is useful to } \\
\text { the nursing discipline? }\end{array}$ & $\begin{array}{l}\text { Valid findings were presented } \\
\text { and the results correlated for } \\
\text { the most part with other } \\
\text { findings published in this field. } \\
\text { This study reinforced the need } \\
\text { for a more spiritually and } \\
\text { culturally sensitive approach to } \\
\text { care delivery that would ensure } \\
\text { that providers really deliver } \\
\text { holistic care. }\end{array}$ \\
\hline
\end{tabular}




\section{Appendix A-4}

\section{Table 4}

\begin{tabular}{|c|c|c|}
\hline Aspect of the Report & Critiquing Questions & Detailed Critiquing Guidelines \\
\hline $\begin{array}{l}\text { Title } \\
\text { The Roles of Religion and } \\
\text { Spirituality Among African } \\
\text { American Survivors of } \\
\text { Domestic Violence. } \\
\text { Watlington, C.G, \& Murphy, } \\
\text { C.M.(2006). }\end{array}$ & $\begin{array}{l}\text { Is the title a good one, } \\
\text { succinctly suggesting key } \\
\text { variables and the study } \\
\text { population? }\end{array}$ & $\begin{array}{l}\text { The title suggested the main } \\
\text { variables which were spirituality } \\
\text { and domestic violence and the } \\
\text { study population which was } \\
\text { African American women. }\end{array}$ \\
\hline Abstract & $\begin{array}{l}\text { Did the abstract clearly and } \\
\text { concisely summarize the } \\
\text { main features of the report } \\
\text { (problem, methods, results, } \\
\text { conclusions)? }\end{array}$ & $\begin{array}{l}\text { The abstract presented the main } \\
\text { points of the article: domestic } \\
\text { violence, method, results of the } \\
\text { inquiry, but not the conclusions. }\end{array}$ \\
\hline $\begin{array}{l}\text { Introduction } \\
\text { Statement of the problem }\end{array}$ & $\begin{array}{l}\text { Was the problem stated } \\
\text { unambiguously, and was it } \\
\text { easy to identify? } \\
\text { Is the problem statement } \\
\text { build a persuasive argument } \\
\text { for the new study? } \\
\text { Was there a good match } \\
\text { between the research } \\
\text { problem and the methods } \\
\text { used -that is, was a } \\
\text { quantitative approach } \\
\text { appropriate? }\end{array}$ & $\begin{array}{l}\text { In the introduction, the extent of } \\
\text { domestic violence and its } \\
\text { consequences were clearly } \\
\text { stated and easy to identify. The } \\
\text { fact that the authors identified } \\
\text { African American women as an } \\
\text { at-risk group for domestic abuse } \\
\text { provided a good argument for } \\
\text { this study. The method was } \\
\text { appropriate. Sixty-five African } \\
\text { American women with history of } \\
\text { domestic violence were part of } \\
\text { the study. }\end{array}$ \\
\hline $\begin{array}{l}\text { Hypotheses or research } \\
\text { questions }\end{array}$ & $\begin{array}{l}\text { Were research questions } \\
\text { and/or hypotheses explicitly } \\
\text { stated? If not, was their } \\
\text { absence justified? } \\
\text { Were questions and } \\
\text { hypotheses appropriately } \\
\text { worded, with clear } \\
\text { specification of key variables } \\
\text { and the study population? } \\
\text { Were the } \\
\text { questions/hypotheses } \\
\text { consistent with existing } \\
\text { knowledge? }\end{array}$ & $\begin{array}{l}\text { The hypotheses were that } \\
\text { religion and spirituality are } \\
\text { related negatively to PTSD and } \\
\text { depression, and that social } \\
\text { support and religious coping } \\
\text { could mediate between religion, } \\
\text { spirituality and PTSD and } \\
\text { depression. The key variables } \\
\text { were domestic violence, } \\
\text { depression, and PTSD. The study } \\
\text { population was African } \\
\text { American women. }\end{array}$ \\
\hline Literature review & $\begin{array}{l}\text { Was the literature review } \\
\text { up-to-date and based } \\
\text { mainly on primary sources? } \\
\text { Did the review provide a } \\
\text { state-of-the-art synthesis of }\end{array}$ & $\begin{array}{l}\text { The literature review consisted } \\
\text { of primary sources and referred } \\
\text { to previous knowledge about } \\
\text { domestic violence, its } \\
\text { characteristics and }\end{array}$ \\
\hline
\end{tabular}




\begin{tabular}{|c|c|c|}
\hline Aspect of the Report & Critiquing Questions & Detailed Critiquing Guidelines \\
\hline & $\begin{array}{l}\text { evidence on the problem? } \\
\text { Did the literature review } \\
\text { provide a strong basis for } \\
\text { the new study? }\end{array}$ & $\begin{array}{l}\text { consequences, and the coping } \\
\text { strategies used by the victims. }\end{array}$ \\
\hline $\begin{array}{l}\text { Conceptual/theoretical } \\
\text { framework }\end{array}$ & $\begin{array}{l}\text { Were key concepts } \\
\text { adequately defined } \\
\text { conceptually? } \\
\text { Was a } \\
\text { conceptual/theoretical } \\
\text { framework articulated- } \\
\text { and, if so, was it } \\
\text { appropriate? If not, is the } \\
\text { absence of a framework } \\
\text { justified? } \\
\text { Were the } \\
\text { questions/hypotheses } \\
\text { consistent with the } \\
\text { framework? }\end{array}$ & $\begin{array}{l}\text { There was not a theoretical } \\
\text { framework attached to this } \\
\text { study. }\end{array}$ \\
\hline $\begin{array}{l}\text { Method } \\
\text { Protection of human rights }\end{array}$ & $\begin{array}{l}\text { Were appropriate } \\
\text { procedures used to safe- } \\
\text { guard the rights of study } \\
\text { participants? } \\
\text { Was the study externally } \\
\text { reviewed by an IRB/ethics } \\
\text { review board? } \\
\text { Was the study designed to } \\
\text { minimize risks and maximize } \\
\text { benefits to participants? }\end{array}$ & $\begin{array}{l}\text { The Institutional Review Board } \\
\text { of the University of Maryland } \\
\text { granted their authorization, and } \\
\text { the participants agreed to sign a } \\
\text { consent. }\end{array}$ \\
\hline Research design & $\begin{array}{l}\text { Was the most rigorous } \\
\text { design used, given the study } \\
\text { purpose? } \\
\text { Were appropriate } \\
\text { comparisons made to } \\
\text { enhance interpretability of } \\
\text { the findings? } \\
\text { Was the number of data } \\
\text { collection points } \\
\text { appropriate? } \\
\text { Did the design minimize } \\
\text { biases and threats to the } \\
\text { internal, construct, and }\end{array}$ & $\begin{array}{l}\text { The research was conducted } \\
\text { using a cross-sectional design. } \\
\text { Data were garnered from } \\
\text { multiple domestic violence } \\
\text { agencies in Maryland and } \\
\text { Washington DC. This method of } \\
\text { collection may enhance the } \\
\text { interpretability of the findings. }\end{array}$ \\
\hline
\end{tabular}




\begin{tabular}{|c|c|c|}
\hline Aspect of the Report & Critiquing Questions & Detailed Critiquing Guidelines \\
\hline & $\begin{array}{l}\text { external validity of the study } \\
\text { (e.g., was blinding used, was } \\
\text { attrition minimized)? }\end{array}$ & \\
\hline Population and sample & $\begin{array}{l}\text { Was the population } \\
\text { identified? Was the sample } \\
\text { described in sufficient } \\
\text { detail? } \\
\text { Was the best possible } \\
\text { sampling design used to } \\
\text { enhance the sample's } \\
\text { representativeness? Were } \\
\text { sampling biases minimized? } \\
\text { Was the sample size based } \\
\text { on a power analysis? }\end{array}$ & $\begin{array}{l}\text { The sample was identified by } \\
\text { ethnicity, educational level, } \\
\text { religious affiliation, income, } \\
\text { marital status, and source of } \\
\text { recruitment. The diversity of } \\
\text { data sources increased the } \\
\text { representativeness of the } \\
\text { sample and decreased biases. A } \\
\text { power analysis used G Power to } \\
\text { determine the sample size. }\end{array}$ \\
\hline $\begin{array}{l}\text { Data collection and } \\
\text { measurement }\end{array}$ & $\begin{array}{l}\text { Were the operational and } \\
\text { conceptual definitions } \\
\text { congruent? } \\
\text { Were key variables } \\
\text { measured using an } \\
\text { appropriate method (e.g., } \\
\text { interviews, observations, } \\
\text { and so on)? } \\
\text { Were specific instruments } \\
\text { adequately described and } \\
\text { were they good choices, } \\
\text { given the study population } \\
\text { and the variables being } \\
\text { studied? } \\
\text { Did the report provide } \\
\text { evidence that the data } \\
\text { collection methods yielded } \\
\text { data that were reliable, valid } \\
\text { and responsive? }\end{array}$ & $\begin{array}{l}\text { The participants were contacted } \\
\text { through domestic violence } \\
\text { agencies. A questionnaire was } \\
\text { distributed to the participants } \\
\text { with questions relative to their } \\
\text { socioeconomic characteristics, } \\
\text { their educational background, } \\
\text { and religious affiliations. Of the } \\
\text { six domestic violence agencies } \\
\text { contacted, five agreed to } \\
\text { participate. Correlations were } \\
\text { used to study the relationship } \\
\text { between dependent variables } \\
\text { like depression and post- } \\
\text { traumatic stress symptoms, and } \\
\text { independent variables such as } \\
\text { spirituality and social support. }\end{array}$ \\
\hline Procedures & $\begin{array}{l}\text { If there was an intervention, } \\
\text { was it adequately described, } \\
\text { and was it rigorously } \\
\text { developed and } \\
\text { implemented? Did most } \\
\text { participants allocated to the } \\
\text { intervention group actually } \\
\text { receive it? Was there } \\
\text { evidence of intervention } \\
\text { fidelity? } \\
\text { Were data collected in a } \\
\text { manner that minimized } \\
\text { bias? Were the staff who } \\
\text { collected data appropriately }\end{array}$ & $\begin{array}{l}\text { There was no intervention } \\
\text { described in this study. }\end{array}$ \\
\hline
\end{tabular}




\begin{tabular}{|c|c|c|}
\hline Aspect of the Report & Critiquing Questions & Detailed Critiquing Guidelines \\
\hline & trained? & \\
\hline Data Analysis & $\begin{array}{l}\text { Were analyses undertaken } \\
\text { to address each research } \\
\text { question or test each } \\
\text { hypothesis? } \\
\text { Were appropriate statistical } \\
\text { methods used, given the } \\
\text { level of measurement of the } \\
\text { variables, number of groups } \\
\text { being compared, and } \\
\text { assumptions of the texts? } \\
\text { Was a powerful analytic } \\
\text { method used? (e.g., did the } \\
\text { analysis help to control for } \\
\text { confounding variables)? } \\
\text { Were type I and Type II } \\
\text { errors avoided or } \\
\text { minimized? } \\
\text { In intervention studies, was } \\
\text { an intention-to-treat } \\
\text { analysis performed? }\end{array}$ & $\begin{array}{l}\text { A power analysis using G Power } \\
\text { was used to determine the } \\
\text { sample size. Variables were } \\
\text { examined for accuracy. } \\
\text { Demographic data were used to } \\
\text { compare studies. Correlations } \\
\text { were used to study the } \\
\text { relationship between dependent } \\
\text { variables like depression and } \\
\text { post-traumatic stress symptoms, } \\
\text { and independent variables such } \\
\text { as spirituality and social support. }\end{array}$ \\
\hline Findings & $\begin{array}{l}\text { Was information about } \\
\text { statistical significance } \\
\text { presented? Was } \\
\text { information about effect } \\
\text { size and precision of } \\
\text { estimates (confidence } \\
\text { intervals) presented? } \\
\text { Were the findings } \\
\text { adequately summarized, } \\
\text { with good use of tables and } \\
\text { figures? } \\
\text { Were findings reported in a } \\
\text { manner that facilitates a } \\
\text { meta-analysis, and with } \\
\text { sufficient information } \\
\text { needed for EBP? }\end{array}$ & $\begin{array}{l}\text { Several tables were used to } \\
\text { summarize the findings. } \\
\text { Independent variable such as } \\
\text { spirituality and social support } \\
\text { were discussed in relationship to } \\
\text { outcome variables depression, } \\
\text { and post-traumatic stress } \\
\text { symptoms. Regression analyses } \\
\text { were conducted when } \\
\text { correlations were significant. } \\
\text { Religious involvement was } \\
\text { associated with higher social } \\
\text { support and less depression and } \\
\text { post-traumatic stress symptoms } \\
\text { were associated with physical } \\
\text { assault and psychological abuse. }\end{array}$ \\
\hline $\begin{array}{l}\text { Discussion } \\
\text { Interpretation of the findings }\end{array}$ & $\begin{array}{l}\text { Were all major findings } \\
\text { interpreted and discussed } \\
\text { within the context of prior } \\
\text { research and/or the study's } \\
\text { conceptual framework? } \\
\text { Were casual inferences, if } \\
\text { any, justified? } \\
\text { Was the issue of clinical } \\
\text { significance discussed? } \\
\text { Were interpretations well- }\end{array}$ & $\begin{array}{l}\text { Current findings were compared } \\
\text { to previous data. For instance, in } \\
\text { one of the studies included in } \\
\text { the review, the authors found } \\
\text { that spirituality was not directly } \\
\text { associated with post-traumatic } \\
\text { symptoms relief, while previous } \\
\text { research stated that women } \\
\text { who were more religious } \\
\text { showed less PTSD related }\end{array}$ \\
\hline
\end{tabular}




\begin{tabular}{|c|c|c|}
\hline Aspect of the Report & Critiquing Questions & Detailed Critiquing Guidelines \\
\hline & $\begin{array}{l}\text { founded and consistent with } \\
\text { the study's limitations? } \\
\text { Did the report address the } \\
\text { issue of the generalizability } \\
\text { of the findings? }\end{array}$ & $\begin{array}{l}\text { symptoms (Astin et al,.1993). } \\
\text { The authors discussed the lack } \\
\text { of a religious and spiritual } \\
\text { training program that resulted in } \\
\text { less cultural sensitivity from the } \\
\text { providers. } \\
\text { The fact that the participants } \\
\text { were only African American } \\
\text { women made it difficult to } \\
\text { generalize the results of this } \\
\text { study. }\end{array}$ \\
\hline $\begin{array}{l}\text { General Issues } \\
\text { Presentation }\end{array}$ & $\begin{array}{l}\text { Was the report well-written, } \\
\text { organized, and sufficiently } \\
\text { detailed for critical analysis? } \\
\text { In intervention studies, was } \\
\text { a CONSORT flowchart } \\
\text { provided to show the flow } \\
\text { of participants in the study? } \\
\text { Was the report written in a } \\
\text { manner that makes the } \\
\text { findings accessible to } \\
\text { practicing nurses? }\end{array}$ & $\begin{array}{l}\text { The report was well-written and } \\
\text { detailed and the findings are } \\
\text { accessible to practicing nurses. } \\
\text { There were several tables } \\
\text { presenting a detailed description } \\
\text { of the participants. } \\
\text { The report was easy to } \\
\text { understand and accessible to } \\
\text { practicing nurses. }\end{array}$ \\
\hline Researcher credibility & $\begin{array}{l}\text { Do the researchers' clinical, } \\
\text { substantive, or } \\
\text { methodologic qualifications } \\
\text { and experience enhance } \\
\text { confidence in the findings } \\
\text { and their interpretation? }\end{array}$ & $\begin{array}{l}\text { The researchers are experienced } \\
\text { professionals who had been } \\
\text { working in clinical psychology for } \\
\text { years. The findings are credible. }\end{array}$ \\
\hline Summary assessment & $\begin{array}{l}\text { Despite any limitations, do } \\
\text { the study findings appear to } \\
\text { be valid-do you have } \\
\text { confidence in the truth } \\
\text { value of the results? } \\
\text { Does the study contribute } \\
\text { any meaningful evidence } \\
\text { that can be used in nursing } \\
\text { practice or that is useful to } \\
\text { the nursing discipline? }\end{array}$ & $\begin{array}{l}\text { Although the authors cited } \\
\text { several limitations such as the } \\
\text { small sample size and the } \\
\text { difficulty to generalize the } \\
\text { findings given the lack of } \\
\text { diversity of the sample, their } \\
\text { research was valid. Findings can } \\
\text { still be used in nursing practice } \\
\text { because domestic abuse is not } \\
\text { an issue limited only to the } \\
\text { African American population. }\end{array}$ \\
\hline
\end{tabular}




\section{Appendix A-5}

\section{Table 5}

\begin{tabular}{|c|c|c|}
\hline Aspect of the Report & Critiquing Questions & Detailed Critiquing Guidelines \\
\hline $\begin{array}{l}\text { Title } \\
\text { Religiosity, spirituality, } \\
\text { mental health, and mental } \\
\text { health outcomes in Australia: } \\
\text { a systematic literature } \\
\text { review. Snider, A.M, \& } \\
\text { McPhedran, S. (2013). }\end{array}$ & $\begin{array}{l}\text { Is the title a good one, } \\
\text { succinctly suggesting key } \\
\text { variables and the study } \\
\text { population? }\end{array}$ & $\begin{array}{l}\text { The title suggests the key } \\
\text { variables that will be part of } \\
\text { this study. }\end{array}$ \\
\hline Abstract & $\begin{array}{l}\text { Did the abstract clearly and } \\
\text { concisely summarize the } \\
\text { main features of the report } \\
\text { (problem, methods, results, } \\
\text { conclusions)? }\end{array}$ & $\begin{array}{l}\text { The abstract summarizes the } \\
\text { problem and the methods, but } \\
\text { failed to mention the results } \\
\text { and the conclusions. }\end{array}$ \\
\hline $\begin{array}{l}\text { Introduction } \\
\text { Statement of the problem }\end{array}$ & $\begin{array}{l}\text { Was the problem stated } \\
\text { unambiguously, and was it } \\
\text { easy to identify? } \\
\text { Is the problem statement } \\
\text { build a persuasive argument } \\
\text { for the new study? } \\
\text { Was there a good match } \\
\text { between the research } \\
\text { problem and the methods } \\
\text { used -that is, was a } \\
\text { quantitative approach } \\
\text { appropriate? }\end{array}$ & $\begin{array}{l}\text { The problem was identified as a } \\
\text { lack of literature in Australia } \\
\text { about the role of } \\
\text { religion/spirituality on mental } \\
\text { health treatment outcomes. It } \\
\text { built a good argument given } \\
\text { that other countries including } \\
\text { The United States are becoming } \\
\text { more aware of the effect of } \\
\text { religion/spirituality on health } \\
\text { outcomes. }\end{array}$ \\
\hline $\begin{array}{l}\text { Hypotheses or research } \\
\text { questions }\end{array}$ & $\begin{array}{l}\text { Were research questions } \\
\text { and/or hypotheses explicitly } \\
\text { stated? If not, was their } \\
\text { absence justified? } \\
\text { Were questions and } \\
\text { hypotheses appropriately } \\
\text { worded, with clear } \\
\text { specification of key variables } \\
\text { and the study population? } \\
\text { Were the } \\
\text { questions/hypotheses } \\
\text { consistent with existing } \\
\text { knowledge? }\end{array}$ & $\begin{array}{l}\text { There were no research } \\
\text { questions or hypotheses clearly } \\
\text { stated. }\end{array}$ \\
\hline Literature review & $\begin{array}{l}\text { Was the literature review up- } \\
\text { to-date and based mainly on } \\
\text { primary sources? } \\
\text { Did the review provide a } \\
\text { state-of-the-art synthesis of }\end{array}$ & $\begin{array}{l}\text { The literature review used } \\
\text { original sources primarily. It } \\
\text { provided a good synthesis of } \\
\text { the problem. Of the } 2051 \\
\text { papers consulted, only } 6\end{array}$ \\
\hline
\end{tabular}




\begin{tabular}{|c|c|c|}
\hline Aspect of the Report & Critiquing Questions & Detailed Critiquing Guidelines \\
\hline & $\begin{array}{l}\text { evidence on the problem? } \\
\text { Did the literature review } \\
\text { provide a strong basis for the } \\
\text { new study? }\end{array}$ & $\begin{array}{l}\text { contained analyses and } \\
\text { empirical data that were } \\
\text { deemed relevant for the } \\
\text { research. }\end{array}$ \\
\hline $\begin{array}{l}\text { Conceptual/theoretical } \\
\text { framework }\end{array}$ & $\begin{array}{l}\text { Were key concepts } \\
\text { adequately defined } \\
\text { conceptually? } \\
\text { Was a conceptual/theoretical } \\
\text { framework articulated-and, } \\
\text { if so, was it appropriate? If } \\
\text { not, is the absence of a } \\
\text { framework justified? } \\
\text { Were the } \\
\text { questions/hypotheses } \\
\text { consistent with the } \\
\text { framework? }\end{array}$ & $\begin{array}{l}\text { The conceptual framework was } \\
\text { not clearly presented. }\end{array}$ \\
\hline $\begin{array}{l}\text { Method } \\
\text { Protection of human rights }\end{array}$ & $\begin{array}{l}\text { Were appropriate } \\
\text { procedures used to safe- } \\
\text { guard the rights of study } \\
\text { participants? } \\
\text { Was the study externally } \\
\text { reviewed by an IRB/ethics } \\
\text { review board? } \\
\text { Was the study designed to } \\
\text { minimize risks and maximize } \\
\text { benefits to participants? }\end{array}$ & $\begin{array}{l}\text { There were no human subjects } \\
\text { involved directly in this study. }\end{array}$ \\
\hline Research design & $\begin{array}{l}\text { Was the most rigorous design } \\
\text { used, given the study } \\
\text { purpose? } \\
\text { Were appropriate } \\
\text { comparisons made to } \\
\text { enhance interpretability of } \\
\text { the findings? } \\
\text { Was the number of data } \\
\text { collection points } \\
\text { appropriate? } \\
\text { Did the design minimize } \\
\text { biases and threats to the } \\
\text { internal, construct, and } \\
\text { external validity of the study } \\
\text { (e.g., was blinding used, was } \\
\text { attrition minimized)? }\end{array}$ & $\begin{array}{l}\text { The design used was a } \\
\text { systematic review of the } \\
\text { literature. } \\
\text { Australia was compared to the } \\
\text { United States and Canada in } \\
\text { terms of literature about the } \\
\text { relationship between } \\
\text { spirituality and mental health } \\
\text { outcomes. They referred to } \\
\text { numerous studies done in other } \\
\text { countries to prove that } \\
\text { Australia was far behind in } \\
\text { terms of these kinds of studies. }\end{array}$ \\
\hline
\end{tabular}




\begin{tabular}{|c|c|c|}
\hline Aspect of the Report & Critiquing Questions & Detailed Critiquing Guidelines \\
\hline Population and sample & $\begin{array}{l}\text { Was the population } \\
\text { identified? Was the sample } \\
\text { described in sufficient detail? } \\
\text { Was the best possible } \\
\text { sampling design used to } \\
\text { enhance the sample's } \\
\text { representativeness? Were } \\
\text { sampling biases minimized? } \\
\text { Was the sample size based } \\
\text { on a power analysis? } \\
\text { Were problems of missing } \\
\text { values evaluated and } \\
\text { adequately addressed? }\end{array}$ & $\begin{array}{l}2051 \text { papers were selected to } \\
\text { be part of this study. } \\
\text { Power analysis was not used to } \\
\text { determine the sample size. } \\
\text { Missing values issues were not } \\
\text { addressed in this study. }\end{array}$ \\
\hline Findings & $\begin{array}{l}\text { Was information about } \\
\text { statistical significance } \\
\text { presented? Was information } \\
\text { about effect size and } \\
\text { precision of estimates } \\
\text { (confidence intervals) } \\
\text { presented? } \\
\text { Were the findings adequately } \\
\text { summarized, with good use } \\
\text { of tables and figures? } \\
\text { Were findings reported in a } \\
\text { manner that facilitates a } \\
\text { meta-analysis, and with } \\
\text { sufficient information } \\
\text { needed for EBP? }\end{array}$ & $\begin{array}{l}\text { The six studies were presented } \\
\text { in a table with several columns } \\
\text { describing the methodology, } \\
\text { the data source, the sample } \\
\text { size, the research questions } \\
\text { and the findings and } \\
\text { conclusions. } \\
\text { Overall, the findings were } \\
\text { summarized in a way that made } \\
\text { it easier to be integrated into } \\
\text { an EBP. They found out that } \\
\text { people can experience } \\
\text { spirituality in different ways } \\
\text { (Wilding et al., 2006), other } \\
\text { stated that spirituality gave } \\
\text { meaning to their lives (Wilding, } \\
\text { 2007). }\end{array}$ \\
\hline $\begin{array}{l}\text { Discussion } \\
\text { Interpretation of the findings }\end{array}$ & $\begin{array}{l}\text { Were all major findings } \\
\text { interpreted and discussed } \\
\text { within the context of prior } \\
\text { research and/or the study's } \\
\text { conceptual framework? } \\
\text { Were casual inferences, if } \\
\text { any, justified? } \\
\text { Was the issue of clinical } \\
\text { significance discussed? } \\
\text { Were interpretations well- } \\
\text { founded and consistent with } \\
\text { the study's limitations? } \\
\text { Did the report address the }\end{array}$ & $\begin{array}{l}\text { Although there were fewer } \\
\text { studies related to spirituality/ } \\
\text { religiosity in Australia } \\
\text { compared to other countries, } \\
\text { the majority of the studies } \\
\text { reported positive effects } \\
\text { associated with } \\
\text { religiosity/spirituality. For } \\
\text { instance, some religious } \\
\text { patients reported higher levels } \\
\text { of social support. They } \\
\text { suggested further exploration } \\
\text { of patient-provider relationship }\end{array}$ \\
\hline
\end{tabular}




\begin{tabular}{|c|c|c|}
\hline Aspect of the Report & Critiquing Questions & Detailed Critiquing Guidelines \\
\hline & $\begin{array}{l}\text { issue of the generalizability } \\
\text { of the findings? }\end{array}$ & $\begin{array}{l}\text { in the context of a dialogue } \\
\text { about spirituality, since it can } \\
\text { be the bridge to healing. }\end{array}$ \\
\hline $\begin{array}{l}\text { Implications/ } \\
\text { recommendations }\end{array}$ & $\begin{array}{l}\text { Did the researchers discuss } \\
\text { the implications of the study } \\
\text { for clinical practice or further } \\
\text { research-and were those } \\
\text { implications reasonable and } \\
\text { complete? }\end{array}$ & $\begin{array}{l}\text { They suggested further } \\
\text { research into the role of } \\
\text { spirituality in people } \\
\text { experiencing suicidal behaviors. }\end{array}$ \\
\hline $\begin{array}{l}\text { General Issues } \\
\text { Presentation }\end{array}$ & $\begin{array}{l}\text { Was the report well-written, } \\
\text { organized, and sufficiently } \\
\text { detailed for critical analysis? } \\
\text { In intervention studies, was a } \\
\text { CONSORT flowchart provided } \\
\text { to show the flow of } \\
\text { participants in the study? } \\
\text { Was the report written in a } \\
\text { manner that makes the } \\
\text { findings accessible to } \\
\text { practicing nurses? }\end{array}$ & $\begin{array}{l}\text { The report was well-written } \\
\text { and detailed enough for critical } \\
\text { analysis. The table presenting } \\
\text { the data was well-organized, } \\
\text { with the main data available. } \\
\text { The data are delivered in a way } \\
\text { that made them accessible to } \\
\text { any practicing nurses. }\end{array}$ \\
\hline Researcher credibility & $\begin{array}{l}\text { Do the researchers' clinical, } \\
\text { substantive, or methodologic } \\
\text { qualifications and experience } \\
\text { enhance confidence in the } \\
\text { findings and their } \\
\text { interpretation? }\end{array}$ & $\begin{array}{l}\text { Both writers hold a doctorate } \\
\text { degree and have been working } \\
\text { in their field for years. Their } \\
\text { credentials add to their } \\
\text { credibility. }\end{array}$ \\
\hline Summary assessment & $\begin{array}{l}\text { Despite any limitations, do } \\
\text { the study findings appear to } \\
\text { be valid-do you have } \\
\text { confidence in the truth value } \\
\text { of the results? } \\
\text { Does the study contribute } \\
\text { any meaningful evidence that } \\
\text { can be used in nursing } \\
\text { practice or that is useful to } \\
\text { the nursing discipline? }\end{array}$ & $\begin{array}{l}\text { Despite the small sample of } \\
\text { studies used, the findings are } \\
\text { valid and the results can be } \\
\text { trusted. } \\
\text { This study can be replicated in } \\
\text { nursing and be used for } \\
\text { advancing nursing knowledge } \\
\text { about the implications of } \\
\text { spirituality/ religiosity in health } \\
\text { outcomes. }\end{array}$ \\
\hline $\begin{array}{l}\text { Data collection and } \\
\text { measurement }\end{array}$ & $\begin{array}{l}\text { Were the operational and } \\
\text { conceptual definitions } \\
\text { congruent? } \\
\text { Were key variables measured } \\
\text { using an appropriate method } \\
\text { (e.g., interviews, } \\
\text { observations, and so on)? } \\
\text { Were specific instruments } \\
\text { adequately described and }\end{array}$ & $\begin{array}{l}\text { The data for this study were } \\
\text { collected online through" Web } \\
\text { of Knowledge" and "Medline". } \\
\text { Keywords used were location, } \\
\text { psych-related, and } \\
\text { religion/spirituality-related. } \\
\text { The inclusion criteria were any } \\
\text { original article that discussed } \\
\text { the relationship between }\end{array}$ \\
\hline
\end{tabular}




\begin{tabular}{|c|c|c|}
\hline Aspect of the Report & Critiquing Questions & Detailed Critiquing Guidelines \\
\hline & $\begin{array}{l}\text { were they good choices, } \\
\text { given the study population } \\
\text { and the variables being } \\
\text { studied? } \\
\text { Did the report provide } \\
\text { evidence that the data } \\
\text { collection methods yielded } \\
\text { data that were reliable, valid } \\
\text { and responsive? }\end{array}$ & $\begin{array}{l}\text { religiosity/spirituality and } \\
\text { psychiatric/psychological health } \\
\text { and/or treatment outcomes. }\end{array}$ \\
\hline Procedures & $\begin{array}{l}\text { If there was an intervention, } \\
\text { was it adequately described, } \\
\text { and was it rigorously } \\
\text { developed and } \\
\text { implemented? Did most } \\
\text { participants allocated to the } \\
\text { intervention group actually } \\
\text { receive it? Was there } \\
\text { evidence of intervention } \\
\text { fidelity? } \\
\text { Were data collected in a } \\
\text { manner that minimized bias? } \\
\text { Were the staff who collected } \\
\text { data appropriately trained? }\end{array}$ & $\begin{array}{l}\text { There was no intervention } \\
\text { described in this study. }\end{array}$ \\
\hline Data Analysis & $\begin{array}{l}\text { Were analyses undertaken to } \\
\text { address each research } \\
\text { question or test each } \\
\text { hypothesis? } \\
\text { Were appropriate statistical } \\
\text { methods used, given the } \\
\text { level of measurement of the } \\
\text { variables, number of groups } \\
\text { being compared, and } \\
\text { assumptions of the texts? } \\
\text { Was a powerful analytic } \\
\text { method used? (e.g., did the } \\
\text { analysis help to control for } \\
\text { confounding variables)? } \\
\text { Were type I and Type II } \\
\text { errors avoided or minimized? } \\
\text { In intervention studies, was } \\
\text { an intention-to-treat analysis } \\
\text { performed? }\end{array}$ & $\begin{array}{l}\text { Each of the six articles that } \\
\text { became part of the studies } \\
\text { used different scales to } \\
\text { demonstrate the relationship } \\
\text { between religiosity/spirituality } \\
\text { and health outcomes. } \\
\text { One of the studies used a } \\
\text { psychological well-being to } \\
\text { assess the positive and negative } \\
\text { effects of religiosity/spirituality, } \\
\text { (Francis \& Kaldor, 2002). }\end{array}$ \\
\hline
\end{tabular}




\section{Appendix A-6}

\section{Table 6}

\begin{tabular}{|c|c|c|}
\hline Aspect of the Report & Critiquing Questions & Detailed Critiquing Guidelines \\
\hline $\begin{array}{l}\text { Title } \\
\text { An increase in } \\
\text { religiousness/spirituality } \\
\text { occurs after HIV } \\
\text { diagnosis and predicts } \\
\text { slower disease } \\
\text { progression over } 4 \text { years } \\
\text { in people with HIV. } \\
\text { Ironson, G., Stuetzle, R., } \\
\text { \& Fletcher, M.A. (2006). }\end{array}$ & $\begin{array}{l}\text { Is the title a good one, succinctly } \\
\text { suggesting key variables and the } \\
\text { study population? }\end{array}$ & $\begin{array}{l}\text { The title suggested the key } \\
\text { variables that are religion and } \\
\text { spirituality, and the study } \\
\text { population represented in this } \\
\text { article by people infected by } \\
\text { HIV. }\end{array}$ \\
\hline Abstract & $\begin{array}{l}\text { Did the abstract clearly and } \\
\text { concisely summarize the main } \\
\text { features of the report (problem, } \\
\text { methods, results, conclusions)? }\end{array}$ & $\begin{array}{l}\text { The abstract included all the } \\
\text { main points of the study: the } \\
\text { problem, the method, the } \\
\text { results, and the conclusions. }\end{array}$ \\
\hline $\begin{array}{l}\text { Introduction } \\
\text { Statement of the } \\
\text { problem }\end{array}$ & $\begin{array}{l}\text { Was the problem stated } \\
\text { unambiguously, and was it easy to } \\
\text { identify? } \\
\text { Is the problem statement build a } \\
\text { persuasive argument for the new } \\
\text { study? } \\
\text { Was there a good match between } \\
\text { the research problem and the } \\
\text { methods used -that is, was a } \\
\text { quantitative approach } \\
\text { appropriate? }\end{array}$ & $\begin{array}{l}\text { It was easy to identify the } \\
\text { problem as the recurrence of } \\
\text { certain studies that limited } \\
\text { spirituality to church } \\
\text { attendance in healthy } \\
\text { individuals, while failing to } \\
\text { study the role of spirituality in } \\
\text { times of crisis. This constituted } \\
\text { a persuasive argument for this } \\
\text { new study. }\end{array}$ \\
\hline $\begin{array}{l}\text { Hypotheses or research } \\
\text { questions }\end{array}$ & $\begin{array}{l}\text { Were research questions and/or } \\
\text { hypotheses explicitly stated? If } \\
\text { not, was their absence justified? } \\
\text { Were questions and hypotheses } \\
\text { appropriately worded, with clear } \\
\text { specification of key variables and } \\
\text { the study population? } \\
\text { Were the questions/hypotheses } \\
\text { consistent with existing } \\
\text { knowledge? }\end{array}$ & $\begin{array}{l}\text { The authors talked about the } \\
\text { impact of spirituality on health } \\
\text { outcomes as an enigma to a } \\
\text { lot of people, and even } \\
\text { researchers. The authors } \\
\text { wondered why only healthy } \\
\text { people were to date, the focus } \\
\text { of studies on the effect of } \\
\text { spirituality. Those questions } \\
\text { were consistent with existing } \\
\text { knowledge about spirituality. }\end{array}$ \\
\hline Literature review & $\begin{array}{l}\text { Was the literature review up-to- } \\
\text { date and based mainly on primary } \\
\text { sources? } \\
\text { Did the review provide a state-of- } \\
\text { the-art synthesis of evidence on }\end{array}$ & $\begin{array}{l}\text { The literature review was up- } \\
\text { to-date and drawn from } \\
\text { empirical sources. } \\
\text { The information collected for } \\
\text { this study were part of a larger }\end{array}$ \\
\hline
\end{tabular}




\begin{tabular}{|c|c|c|}
\hline Aspect of the Report & Critiquing Questions & Detailed Critiquing Guidelines \\
\hline & $\begin{array}{l}\text { the problem? } \\
\text { Did the literature review provide a } \\
\text { strong basis for the new study? }\end{array}$ & $\begin{array}{l}\text { inquiry about the } \\
\text { psychological and biological } \\
\text { factors related to disease } \\
\text { progression in HIV. }\end{array}$ \\
\hline $\begin{array}{l}\text { Conceptual/theoretical } \\
\text { framework }\end{array}$ & $\begin{array}{l}\text { Were key concepts adequately } \\
\text { defined conceptually? } \\
\text { Was a conceptual/theoretical } \\
\text { framework articulated-and, if so, } \\
\text { was it appropriate? If not, is the } \\
\text { absence of a framework justified? } \\
\text { Were the questions/hypotheses } \\
\text { consistent with the framework? }\end{array}$ & $\begin{array}{l}\text { The conceptual framework } \\
\text { used was not described in this } \\
\text { study. }\end{array}$ \\
\hline $\begin{array}{l}\text { Method } \\
\text { Protection of human } \\
\text { rights }\end{array}$ & $\begin{array}{l}\text { Were appropriate procedures used } \\
\text { to safe-guard the rights of study } \\
\text { participants? } \\
\text { Was the study externally reviewed } \\
\text { by an IRB/ethics review board? } \\
\text { Was the study designed to } \\
\text { minimize risks and maximize } \\
\text { benefits to participants? }\end{array}$ & $\begin{array}{l}\text { The study was approved by } \\
\text { the Institutional Review Board. } \\
\text { The participants gave their } \\
\text { consent and were } \\
\text { compensated for their } \\
\text { contribution. }\end{array}$ \\
\hline Research design & $\begin{array}{l}\text { Was the most rigorous design } \\
\text { used, given the study purpose? } \\
\text { Were appropriate comparisons } \\
\text { made to enhance interpretability } \\
\text { of the findings? } \\
\text { Was the number of data collection } \\
\text { points appropriate? } \\
\text { Did the design minimize biases and } \\
\text { threats to the internal, construct, } \\
\text { and external validity of the study } \\
\text { (e.g., was blinding used, was } \\
\text { attrition minimized)? }\end{array}$ & $\begin{array}{l}\text { They used a longitudinal } \\
\text { approach for this study. } \\
\text { Several variables were used to } \\
\text { make the interpretation } \\
\text { easier. Those variables were } \\
\text { the CD4 and the viral load } \\
\text { levels. They talked about a } \\
\text { larger longitudinal study as } \\
\text { their source of data. }\end{array}$ \\
\hline Population and sample & $\begin{array}{l}\text { Was the population identified? } \\
\text { Was the sample described in } \\
\text { sufficient detail? } \\
\text { Was the best possible sampling } \\
\text { design used to enhance the } \\
\text { sample's representativeness? } \\
\text { Were sampling biases minimized? } \\
\text { Was the sample size based on a } \\
\text { power analysis? }\end{array}$ & $\begin{array}{l}\text { The sample was identified as } \\
\text { hundred people living with } \\
\text { HIV. They represented a } \\
\text { diverse sample in their } \\
\text { education, their ethnicity, } \\
\text { their sexual orientation, their } \\
\text { economic status, and their } \\
\text { level of spirituality. } \\
\text { Power analysis was used to } \\
\text { determine the sample size. }\end{array}$ \\
\hline $\begin{array}{l}\text { Data collection and } \\
\text { measurement }\end{array}$ & $\begin{array}{l}\text { Were the operational and } \\
\text { conceptual definitions congruent? } \\
\text { Were key variables measured using } \\
\text { an appropriate method (e.g., }\end{array}$ & $\begin{array}{l}\text { The subjects were asked to } \\
\text { sign an agreement. Then, they } \\
\text { responded to a questionnaire } \\
\text { where they provided their }\end{array}$ \\
\hline
\end{tabular}




\begin{tabular}{|c|c|c|}
\hline Aspect of the Report & Critiquing Questions & Detailed Critiquing Guidelines \\
\hline & $\begin{array}{l}\text { interviews, observations, and so } \\
\text { on)? } \\
\text { Were specific instruments } \\
\text { adequately described and were } \\
\text { they good choices, given the study } \\
\text { population and the variables being } \\
\text { studied? } \\
\text { Did the report provide evidence } \\
\text { that the data collection methods } \\
\text { yielded data that were reliable, } \\
\text { valid and responsive? }\end{array}$ & $\begin{array}{l}\text { demographic data and other } \\
\text { information related to this } \\
\text { study. } \\
\text { Other variables described } \\
\text { were their health behaviors } \\
\text { such as risky sexual conducts, } \\
\text { some psychosocial measures } \\
\text { such as coping strategies, level } \\
\text { of optimism, and social } \\
\text { support. } \\
\text { The disease progression } \\
\text { markers like CD4 and viral load } \\
\text { were other measurement } \\
\text { used. The participants' blood } \\
\text { was drawn every six months } \\
\text { for four years to check their } \\
\text { CD4 level and viral load. }\end{array}$ \\
\hline Procedures & $\begin{array}{l}\text { If there was an intervention, was it } \\
\text { adequately described, and was it } \\
\text { rigorously developed and } \\
\text { implemented? Did most } \\
\text { participants allocated to the } \\
\text { intervention group actually receive } \\
\text { it? Was there evidence of } \\
\text { intervention fidelity? } \\
\text { Were data collected in a manner } \\
\text { that minimized bias? Were the } \\
\text { staff who collected data } \\
\text { appropriately trained? }\end{array}$ & $\begin{array}{l}\text { No intervention has been } \\
\text { described, neither the } \\
\text { competence of the staff } \\
\text { collecting the information. }\end{array}$ \\
\hline Data Analysis & $\begin{array}{l}\text { Were analyses undertaken to } \\
\text { address each research question or } \\
\text { test each hypothesis? } \\
\text { Were appropriate statistical } \\
\text { methods used, given the level of } \\
\text { measurement of the variables, } \\
\text { number of groups being compared, } \\
\text { and assumptions of the texts? } \\
\text { Was a powerful analytic method } \\
\text { used? (e.g., did the analysis help } \\
\text { to control for confounding } \\
\text { variables)? } \\
\text { Were type I and Type II errors } \\
\text { avoided or minimized? } \\
\text { In intervention studies, was an } \\
\text { intention-to-treat analysis } \\
\text { performed? } \\
\text { Were problems of missing values }\end{array}$ & $\begin{array}{l}\text { The Hierarchical Linear } \\
\text { Modeling (HLM) was used to } \\
\text { measure the association } \\
\text { between the INCRS that } \\
\text { stands for the increase in } \\
\text { religiousness/spirituality and } \\
\text { the CD4 and the viral load } \\
\text { levels. } \\
\text { The HLM allowed to control } \\
\text { variables that could change } \\
\text { overtime such as CD4 and viral } \\
\text { load. } \\
\text { According to the authors, } \\
\text { missing data were minimal. }\end{array}$ \\
\hline
\end{tabular}




\begin{tabular}{|c|c|c|}
\hline Aspect of the Report & Critiquing Questions & Detailed Critiquing Guidelines \\
\hline & $\begin{array}{l}\text { evaluated and adequately } \\
\text { addressed? }\end{array}$ & \\
\hline Findings & $\begin{array}{l}\text { Was information about statistical } \\
\text { significance presented? Was } \\
\text { information about effect size and } \\
\text { precision of estimates (confidence } \\
\text { intervals) presented? } \\
\text { Were the findings adequately } \\
\text { summarized, with good use of } \\
\text { tables and figures? } \\
\text { Were findings reported in a } \\
\text { manner that facilitates a meta- } \\
\text { analysis, and with sufficient } \\
\text { information needed for EBP? }\end{array}$ & $\begin{array}{l}\text { Several tables and figures } \\
\text { were used to present the } \\
\text { findings. } \\
\text { Data about the effect size } \\
\text { were presented in a table. A } \\
\text { formula explaining how to } \\
\text { calculate the effect size was } \\
\text { also provided. } \\
\text { The way the information was } \\
\text { presented could make it easier } \\
\text { for EBP. }\end{array}$ \\
\hline $\begin{array}{l}\text { Discussion } \\
\text { Interpretation of the } \\
\text { findings }\end{array}$ & $\begin{array}{l}\text { Were all major findings interpreted } \\
\text { and discussed within the context of } \\
\text { prior research and/or the study's } \\
\text { conceptual framework? } \\
\text { Were casual inferences, if any, } \\
\text { justified? } \\
\text { Was the issue of clinical } \\
\text { significance discussed? } \\
\text { Were interpretations well-founded } \\
\text { and consistent with the study's } \\
\text { limitations? } \\
\text { Did the report address the issue of } \\
\text { the generalizability of the findings? }\end{array}$ & $\begin{array}{l}\text { The findings were discussed in } \\
\text { relationship to the larger study } \\
\text { that they draw data from. } \\
\text { They reported an increase in } \\
\text { spirituality in } 45 \% \text { of the } \\
\text { people contacted after they } \\
\text { contracted the disease. } 50 \% \text { of } \\
\text { the respondents reported that } \\
\text { their spirituality/religiosity } \\
\text { helped them live longer. } \\
\text { They mentioned that } \\
\text { providers should take these } \\
\text { findings into consideration in } \\
\text { order to help patients achieve } \\
\text { well-being. }\end{array}$ \\
\hline $\begin{array}{l}\text { Implications/ } \\
\text { recommendations }\end{array}$ & $\begin{array}{l}\text { Did the researchers discuss the } \\
\text { implications of the study for clinical } \\
\text { practice or further research-and } \\
\text { were those implications } \\
\text { reasonable and complete? }\end{array}$ & $\begin{array}{l}\text { The researchers encouraged } \\
\text { providers to be more } \\
\text { receptive to their patients' } \\
\text { spiritual needs and be more } \\
\text { open to discuss these sensitive } \\
\text { subjects. }\end{array}$ \\
\hline
\end{tabular}




\begin{tabular}{|l|l|l|}
\hline Aspect of the Report & Critiquing Questions & Detailed Critiquing Guidelines \\
\hline $\begin{array}{l}\text { General Issues } \\
\text { Presentation }\end{array}$ & $\begin{array}{l}\text { Was the report well-written, } \\
\text { organized, and sufficiently detailed } \\
\text { for critical analysis? } \\
\text { In intervention studies, was a } \\
\text { CONSORT flowchart provided to } \\
\text { show the flow of participants in the } \\
\text { study? } \\
\text { Was the report written in a } \\
\text { manner that makes the findings } \\
\text { accessible to practicing nurses? }\end{array}$ & $\begin{array}{l}\text { The study was well-organized } \\
\text { and suffient details were } \\
\text { provided for analysis. A } \\
\text { flowchart was presented with } \\
\text { the profile of the participants. } \\
\text { Any practicing provider can } \\
\text { have access to this report. The } \\
\text { flow was easy to follow. }\end{array}$ \\
\hline Researcher credibility & $\begin{array}{l}\text { Do the researchers' clinical, } \\
\text { substantive, or methodologic } \\
\text { qualifications and experience } \\
\text { enhance confidence in the findings } \\
\text { and their interpretation? }\end{array}$ & $\begin{array}{l}\text { The researchers' qualification } \\
\text { added a level of credibility to } \\
\text { the findings and their } \\
\text { interpretations. }\end{array}$ \\
\hline Summary assessment & $\begin{array}{l}\text { Despite any limitations, do the } \\
\text { study findings appear to be valid- } \\
\text { do you have confidence in the } \\
\text { truth value of the results? } \\
\text { Does the study contribute any } \\
\text { meaningful evidence that can be } \\
\text { used in nursing practice or that is } \\
\text { useful to the nursing discipline? }\end{array}$ & $\begin{array}{l}\text { The findings are credible } \\
\text { despite the limitations of the } \\
\text { study. Those findings } \\
\text { represent additional resources } \\
\text { that can be used in practice to } \\
\text { enhance patients' well-being. }\end{array}$ \\
\hline
\end{tabular}




\section{Appendix A-7}

\section{Table 7}

\begin{tabular}{|c|c|c|}
\hline Aspect of the Report & Critiquing Questions & Detailed Critiquing Guidelines \\
\hline $\begin{array}{l}\text { Title } \\
\text { Research on religion, } \\
\text { spirituality, and mental } \\
\text { health: A review. } \\
\text { Koenig, H.G. (2009). }\end{array}$ & $\begin{array}{l}\text { Is the title a good one, succinctly } \\
\text { suggesting key variables and the } \\
\text { study population? }\end{array}$ & $\begin{array}{l}\text { The title addressed the main } \\
\text { variables of the study: religion, } \\
\text { spirituality, depression, anxiety, } \\
\text { psychosis, substance abuse. }\end{array}$ \\
\hline Abstract & $\begin{array}{l}\text { Did the abstract clearly and } \\
\text { concisely summarize the main } \\
\text { features of the report (problem, } \\
\text { methods, results, conclusions)? }\end{array}$ & $\begin{array}{l}\text { The abstract summarized the } \\
\text { problem, the method, the results, } \\
\text { but did not provide a conclusion. }\end{array}$ \\
\hline $\begin{array}{l}\text { Introduction } \\
\text { Statement of the } \\
\text { problem }\end{array}$ & $\begin{array}{l}\text { Was the problem stated } \\
\text { unambiguously, and was it easy } \\
\text { to identify? } \\
\text { Is the problem statement build a } \\
\text { persuasive argument for the new } \\
\text { study? } \\
\text { Was there a good match } \\
\text { between the research problem } \\
\text { and the methods used -that is, } \\
\text { was a quantitative approach } \\
\text { appropriate? }\end{array}$ & $\begin{array}{l}\text { The problem was identified as the } \\
\text { opposite views that people hold } \\
\text { on the association of spirituality } \\
\text { and religion with mental health } \\
\text { outcomes. The problem statement } \\
\text { built the case for a newer } \\
\text { assessment of spirituality's role } \\
\text { and what it means to people with } \\
\text { mental health issues. Quantitative } \\
\text { data were used to describe the } \\
\text { sample used in the original } \\
\text { studies. }\end{array}$ \\
\hline $\begin{array}{l}\text { Hypotheses or } \\
\text { research questions }\end{array}$ & $\begin{array}{l}\text { Were research questions and/or } \\
\text { hypotheses explicitly stated? If } \\
\text { not, was their absence justified? } \\
\text { Were questions and hypotheses } \\
\text { appropriately worded, with clear } \\
\text { specification of key variables and } \\
\text { the study population? } \\
\text { Were the questions/hypotheses } \\
\text { consistent with existing } \\
\text { knowledge? }\end{array}$ & $\begin{array}{l}\text { The research questions were not } \\
\text { stated. The author explained that } \\
\text { he conducted a selective review of } \\
\text { literature instead of a systematic } \\
\text { one. }\end{array}$ \\
\hline Literature review & $\begin{array}{l}\text { Was the literature review up-to- } \\
\text { date and based mainly on } \\
\text { primary sources? } \\
\text { Did the review provide a state-of- } \\
\text { the-art synthesis of evidence on } \\
\text { the problem? } \\
\text { Did the literature review provide } \\
\text { a strong basis for the new study? }\end{array}$ & $\begin{array}{l}\text { Empirical literatures represented } \\
\text { the main sources of data } \\
\text { collection. } \\
\text { The review provided a wide range } \\
\text { of information about the } \\
\text { perceived role of spirituality on } \\
\text { health outcomes. }\end{array}$ \\
\hline $\begin{array}{l}\text { Conceptual/theoretical } \\
\text { framework }\end{array}$ & $\begin{array}{l}\text { Were key concepts adequately } \\
\text { defined conceptually? } \\
\text { Was a conceptual/theoretical } \\
\text { framework articulated-and, if }\end{array}$ & $\begin{array}{l}\text { There was no conceptual } \\
\text { framework described for this } \\
\text { study. }\end{array}$ \\
\hline
\end{tabular}




\begin{tabular}{|c|c|c|}
\hline Aspect of the Report & Critiquing Questions & Detailed Critiquing Guidelines \\
\hline & $\begin{array}{l}\text { so, was it appropriate? If not, is } \\
\text { the absence of a framework } \\
\text { justified? } \\
\text { Were the questions/hypotheses } \\
\text { consistent with the framework? }\end{array}$ & \\
\hline $\begin{array}{l}\text { Method } \\
\text { Protection of human } \\
\text { rights }\end{array}$ & $\begin{array}{l}\text { Were appropriate procedures } \\
\text { used to safe-guard the rights of } \\
\text { study participants? } \\
\text { Was the study externally } \\
\text { reviewed by an IRB/ethics review } \\
\text { board? } \\
\text { Was the study designed to } \\
\text { minimize risks and maximize } \\
\text { benefits to participants? }\end{array}$ & $\begin{array}{l}\text { There were no human subjects } \\
\text { directly involved in this study. }\end{array}$ \\
\hline Research design & $\begin{array}{l}\text { Was the most rigorous design } \\
\text { used, given the study purpose? } \\
\text { Were appropriate comparisons } \\
\text { made to enhance interpretability } \\
\text { of the findings? } \\
\text { Was the number of data } \\
\text { collection points appropriate? } \\
\text { Did the design minimize biases } \\
\text { and threats to the internal, } \\
\text { construct, and external validity of } \\
\text { the study (e.g., was blinding } \\
\text { used, was attrition minimized)? }\end{array}$ & $\begin{array}{l}\text { The research design used was a } \\
\text { selective review of the literature. } \\
\text { Although the review was selective, } \\
\text { studies using different designs } \\
\text { were selected in order to enhance } \\
\text { the interpretation of the findings. } \\
\text { Data were collected about the role } \\
\text { of religion/spirituality on } \\
\text { substance abuse, suicidal } \\
\text { tendencies, anxiety, depression, } \\
\text { and psychotic disorders. }\end{array}$ \\
\hline Population and sample & $\begin{array}{l}\text { Was the population identified? } \\
\text { Was the sample described in } \\
\text { sufficient detail? Was the best } \\
\text { possible sampling design used to } \\
\text { enhance the sample's } \\
\text { representativeness? Were } \\
\text { sampling biases minimized? } \\
\text { Was the sample size based on a } \\
\text { power analysis? }\end{array}$ & $\begin{array}{l}\text { The population was described as } \\
\text { individuals with mental health } \\
\text { issues. There were no } \\
\text { demographic data or any other } \\
\text { characteristics described. } \\
\text { The sample size was not based on } \\
\text { power analysis. }\end{array}$ \\
\hline $\begin{array}{l}\text { Data collection and } \\
\text { measurement }\end{array}$ & $\begin{array}{l}\text { Were the operational and } \\
\text { conceptual definitions } \\
\text { congruent? } \\
\text { Were key variables measured } \\
\text { using an appropriate method } \\
\text { (e.g., interviews, observations, } \\
\text { and so on)? } \\
\text { Were specific instruments } \\
\text { adequately described and were } \\
\text { they good choices, given the } \\
\text { study population and the }\end{array}$ & $\begin{array}{l}\text { The concepts religion and } \\
\text { spirituality were defined although } \\
\text { the authors did not separate them } \\
\text { when discussing their impact on } \\
\text { mental health. } \\
\text { Key variables representing various } \\
\text { forms of mental diseases like } \\
\text { depression, anxiety, and psychotic } \\
\text { disorders were described in the } \\
\text { literature. } \\
\text { The fact that studies with different }\end{array}$ \\
\hline
\end{tabular}




\begin{tabular}{|c|c|c|}
\hline Aspect of the Report & Critiquing Questions & Detailed Critiquing Guidelines \\
\hline & $\begin{array}{l}\text { variables being studied? } \\
\text { Did the report provide evidence } \\
\text { that the data collection methods } \\
\text { yielded data that were reliable, } \\
\text { valid and responsive? }\end{array}$ & $\begin{array}{l}\text { designs were used increase the } \\
\text { reliability of the report. }\end{array}$ \\
\hline Procedures & $\begin{array}{l}\text { If there was an intervention, was } \\
\text { it adequately described, and was } \\
\text { it rigorously developed and } \\
\text { implemented? Did most } \\
\text { participants allocated to the } \\
\text { intervention group actually } \\
\text { receive it? Was there evidence } \\
\text { of intervention fidelity? } \\
\text { Were data collected in a manner } \\
\text { that minimized bias? Were the } \\
\text { staff who collected data } \\
\text { appropriately trained? }\end{array}$ & $\begin{array}{l}\text { There was not an intervention } \\
\text { presented in this study. }\end{array}$ \\
\hline Data Analysis & $\begin{array}{l}\text { Were analyses undertaken to } \\
\text { address each research question } \\
\text { or test each hypothesis? } \\
\text { Were appropriate statistical } \\
\text { methods used, given the level of } \\
\text { measurement of the variables, } \\
\text { number of groups being } \\
\text { compared, and assumptions of } \\
\text { the texts? } \\
\text { Was a powerful analytic method } \\
\text { used? (e.g., did the analysis help } \\
\text { to control for confounding } \\
\text { variables)? } \\
\text { Were type I and Type II errors } \\
\text { avoided or minimized? } \\
\text { In intervention studies, was an } \\
\text { intention-to-treat analysis } \\
\text { performed? } \\
\text { Were problems of missing values } \\
\text { evaluated and adequately } \\
\text { addressed? }\end{array}$ & $\begin{array}{l}\text { Although the original studies } \\
\text { contained some statistical } \\
\text { analyses, the author did not use } \\
\text { any statistical method himself. } \\
\text { Missing values were not } \\
\text { addressed in this report. }\end{array}$ \\
\hline
\end{tabular}




\begin{tabular}{|c|c|c|}
\hline Aspect of the Report & Critiquing Questions & Detailed Critiquing Guidelines \\
\hline Findings & $\begin{array}{l}\text { Was information about statistical } \\
\text { significance presented? Was } \\
\text { information about effect size and } \\
\text { precision of estimates } \\
\text { (confidence intervals) presented? } \\
\text { Were the findings adequately } \\
\text { summarized, with good use of } \\
\text { tables and figures? } \\
\text { Were findings reported in a } \\
\text { manner that facilitates a meta- } \\
\text { analysis, and with sufficient } \\
\text { information needed for EBP? }\end{array}$ & $\begin{array}{l}\text { The findings were not presented } \\
\text { in tables. Although the author } \\
\text { mentioned that he only presented } \\
\text { articles with statistically significant } \\
\text { data, he did not significantly use } \\
\text { statistical data to present his } \\
\text { findings. } \\
\text { They found out lower rate of } \\
\text { depression in people identified as } \\
\text { more religious. } \\
\text { In } 8 \text { RCTs, } 5 \text { found that religious- } \\
\text { based psychological interventions } \\
\text { resulted in a faster recovery. }\end{array}$ \\
\hline $\begin{array}{l}\text { Discussion } \\
\text { Interpretation of the } \\
\text { findings }\end{array}$ & $\begin{array}{l}\text { Were all major findings } \\
\text { interpreted and discussed within } \\
\text { the context of prior research } \\
\text { and/or the study's conceptual } \\
\text { framework? } \\
\text { Were casual inferences, if any, } \\
\text { justified? } \\
\text { Was the issue of clinical } \\
\text { significance discussed? } \\
\text { Were interpretations well- } \\
\text { founded and consistent with the } \\
\text { study's limitations? } \\
\text { Did the report address the issue } \\
\text { of the generalizability of the } \\
\text { findings? }\end{array}$ & $\begin{array}{l}\text { The findings were interpreted in } \\
\text { reference to prior studies about } \\
\text { the subject. } \\
\text { The writer encouraged providers } \\
\text { to take into account the religious } \\
\text { and spiritual beliefs of their } \\
\text { patients, since they can be } \\
\text { important resources for coping } \\
\text { skills learning, but also cautioned } \\
\text { about the role of some religious } \\
\text { beliefs in triggering mental } \\
\text { diseases. }\end{array}$ \\
\hline $\begin{array}{l}\text { Implications/ } \\
\text { recommendations }\end{array}$ & $\begin{array}{l}\text { Did the researchers discuss the } \\
\text { implications of the study for } \\
\text { clinical practice or further } \\
\text { research-and were those } \\
\text { implications reasonable and } \\
\text { complete? }\end{array}$ & $\begin{array}{l}\text { The fact that clinical applications } \\
\text { were not addressed constituted } \\
\text { one of the limitations of the study. }\end{array}$ \\
\hline $\begin{array}{l}\text { General Issues } \\
\text { Presentation }\end{array}$ & $\begin{array}{l}\text { Was the report well-written, } \\
\text { organized, and sufficiently } \\
\text { detailed for critical analysis? } \\
\text { In intervention studies, was a } \\
\text { CONSORT flowchart provided to } \\
\text { show the flow of participants in } \\
\text { the study? } \\
\text { Was the report written in a } \\
\text { manner that makes the findings } \\
\text { accessible to practicing nurses? }\end{array}$ & $\begin{array}{l}\text { The report was well-written, and } \\
\text { organized, but the selectivity of } \\
\text { studies may limit the amount } \\
\text { information available for a } \\
\text { detailed analysis. There was no } \\
\text { flowchart presented. } \\
\text { The report was redacted in a way } \\
\text { that makes it accessible to any } \\
\text { practicing nurses. }\end{array}$ \\
\hline
\end{tabular}




\begin{tabular}{|c|c|c|}
\hline Aspect of the Report & Critiquing Questions & Detailed Critiquing Guidelines \\
\hline Researcher credibility & $\begin{array}{l}\text { Do the researchers' clinical, } \\
\text { substantive, or methodologic } \\
\text { qualifications and experience } \\
\text { enhance confidence in the } \\
\text { findings and their interpretation? }\end{array}$ & $\begin{array}{l}\text { The writer, Dr. Koenig is a } \\
\text { psychiatrist, a prolific writer in the } \\
\text { field of spirituality. His experience } \\
\text { enhanced the confidence in the } \\
\text { findings. }\end{array}$ \\
\hline Summary assessment & $\begin{array}{l}\text { Despite any limitations, do the } \\
\text { study findings appear to be } \\
\text { valid-do you have confidence in } \\
\text { the truth value of the results? } \\
\text { Does the study contribute any } \\
\text { meaningful evidence that can be } \\
\text { used in nursing practice or that is } \\
\text { useful to the nursing discipline? }\end{array}$ & $\begin{array}{l}\text { The results were valid despite the } \\
\text { limitations. } \\
\text { This report can be used in nursing } \\
\text { practice to assess patients' beliefs } \\
\text { and the way to use them to their } \\
\text { advantages. }\end{array}$ \\
\hline
\end{tabular}




\section{Appendix A-8}

\section{Table 8}

\begin{tabular}{|c|c|c|}
\hline Aspect of the Report & Critiquing Questions & Detailed Critiquing Guidelines \\
\hline $\begin{array}{l}\text { Title } \\
\text { Religiousness and } \\
\text { spirituality in patients } \\
\text { with bipolar disorder. } \\
\text { De Fazio,P., } \\
\text { Gaetano,R., } \\
\text { Caroleo, M., } \\
\text { Cerminara, G., } \\
\text { Giannini, F.,....,Segura- } \\
\text { Garcia, C. (2015). }\end{array}$ & $\begin{array}{l}\text { Is the title a good one, succinctly } \\
\text { suggesting key variables and the } \\
\text { study population? }\end{array}$ & $\begin{array}{l}\text { The key variables mentioned in } \\
\text { this study are included in this } \\
\text { study: religiousness, spirituality, } \\
\text { and bipolar disorder. }\end{array}$ \\
\hline Abstract & $\begin{array}{l}\text { Did the abstract clearly and } \\
\text { concisely summarize the main } \\
\text { features of the report (problem, } \\
\text { methods, results, conclusions)? }\end{array}$ & $\begin{array}{l}\text { The abstract summarized the key } \\
\text { points of the study: problem, } \\
\text { methods, results, and conclusions. }\end{array}$ \\
\hline $\begin{array}{l}\text { Introduction } \\
\text { Statement of the } \\
\text { problem }\end{array}$ & $\begin{array}{l}\text { Was the problem stated } \\
\text { unambiguously, and was it easy } \\
\text { to identify? } \\
\text { Is the problem statement build a } \\
\text { persuasive argument for the new } \\
\text { study? } \\
\text { Was there a good match } \\
\text { between the research problem } \\
\text { and the methods used -that is, } \\
\text { was a quantitative approach } \\
\text { appropriate? }\end{array}$ & $\begin{array}{l}\text { The problem was stated as a lack } \\
\text { of studies focusing on the } \\
\text { relationship between } \\
\text { religion/spirituality and bipolar } \\
\text { disorder. } \\
\text { The poor attention that religion } \\
\text { and spirituality receive as coping } \\
\text { mechanisms in mental health, } \\
\text { built the argument for the new } \\
\text { study. }\end{array}$ \\
\hline $\begin{array}{l}\text { Hypotheses or } \\
\text { research questions }\end{array}$ & $\begin{array}{l}\text { Were research questions and/or } \\
\text { hypotheses explicitly stated? If } \\
\text { not, was their absence justified? } \\
\text { Were questions and hypotheses } \\
\text { appropriately worded, with clear } \\
\text { specification of key variables and } \\
\text { the study population? } \\
\text { Were the questions/hypotheses } \\
\text { consistent with existing } \\
\text { knowledge? }\end{array}$ & $\begin{array}{l}\text { There was not a clearly stated } \\
\text { hypothesis, but the key variables } \\
\text { were religiousness and spirituality. } \\
\text { The study population was clearly } \\
\text { stated as people affected with } \\
\text { bipolar disorder. }\end{array}$ \\
\hline Literature review & $\begin{array}{l}\text { Was the literature review up-to- } \\
\text { date and based mainly on } \\
\text { primary sources? } \\
\text { Did the review provide a state-of- } \\
\text { the-art synthesis of evidence on } \\
\text { the problem? } \\
\text { Did the literature review provide } \\
\text { a strong basis for the new study? }\end{array}$ & $\begin{array}{l}\text { The literature review was based } \\
\text { mostly on primary sources that } \\
\text { provided a good synthesis of the } \\
\text { problem, but the small amount of } \\
\text { studies limited the scope of the } \\
\text { synthesis. }\end{array}$ \\
\hline
\end{tabular}




\begin{tabular}{|c|c|c|}
\hline Aspect of the Report & Critiquing Questions & Detailed Critiquing Guidelines \\
\hline $\begin{array}{l}\text { Conceptual/theoretica } \\
\text { I framework }\end{array}$ & $\begin{array}{l}\text { Were key concepts adequately } \\
\text { defined conceptually? } \\
\text { Was a conceptual/theoretical } \\
\text { framework articulated-and, if } \\
\text { so, was it appropriate? If not, is } \\
\text { the absence of a framework } \\
\text { justified? } \\
\text { Were the questions/hypotheses } \\
\text { consistent with the framework? }\end{array}$ & $\begin{array}{l}\text { The conceptual framework was } \\
\text { not defined, or even mentioned in } \\
\text { this study. }\end{array}$ \\
\hline $\begin{array}{l}\text { Method } \\
\text { Protection of human } \\
\text { rights }\end{array}$ & $\begin{array}{l}\text { Were appropriate procedures } \\
\text { used to safe-guard the rights of } \\
\text { study participants? } \\
\text { Was the study externally } \\
\text { reviewed by an IRB/ethics review } \\
\text { board? } \\
\text { Was the study designed to } \\
\text { minimize risks and maximize } \\
\text { benefits to participants? }\end{array}$ & $\begin{array}{l}\text { Human subjects were not part of } \\
\text { this study directly. }\end{array}$ \\
\hline Research design & $\begin{array}{l}\text { Was the most rigorous design } \\
\text { used, given the study purpose? } \\
\text { Were appropriate comparisons } \\
\text { made to enhance interpretability } \\
\text { of the findings? } \\
\text { Was the number of data } \\
\text { collection points appropriate? } \\
\text { Did the design minimize biases } \\
\text { and threats to the internal, } \\
\text { construct, and external validity of } \\
\text { the study (e.g., was blinding } \\
\text { used, was attrition minimized)? }\end{array}$ & $\begin{array}{l}\text { The design used was a review of } \\
\text { the literature where a total of five } \\
\text { studies were reviewed and their } \\
\text { data compared. } \\
\text { The number of studies was limited } \\
\text { to only five, but the data collection } \\
\text { point was appropriate since each } \\
\text { study had an appropriate sample. }\end{array}$ \\
\hline Population and sample & $\begin{array}{l}\text { Was the population identified? } \\
\text { Was the sample described in } \\
\text { sufficient detail? } \\
\text { Was the best possible sampling } \\
\text { design used to enhance the } \\
\text { sample's representativeness? } \\
\text { Weresampling biases minimized? } \\
\text { Was the sample size based on a } \\
\text { power analysis? }\end{array}$ & $\begin{array}{l}\text { The population was identified in } \\
\text { terms of their diagnosis. No } \\
\text { demographic or socioeconomic } \\
\text { data were provided. } \\
\text { The sample design was diverse } \\
\text { enough. Clients were recruited in } \\
\text { hospital, in outpatient clinics, or } \\
\text { reached at home. }\end{array}$ \\
\hline $\begin{array}{l}\text { Data collection and } \\
\text { measurement }\end{array}$ & $\begin{array}{l}\text { Were the operational and } \\
\text { conceptual definitions } \\
\text { congruent? } \\
\text { Were key variables measured } \\
\text { using an appropriate method } \\
\text { (e.g., interviews, observations, } \\
\text { and so on)? }\end{array}$ & $\begin{array}{l}\text { Some patients were interviewed } \\
\text { while others were reached via a } \\
\text { questionnaire. } \\
\text { The interviews were taped, and } \\
\text { the questionnaires were adapted } \\
\text { from the Royal free interview for } \\
\text { religious beliefs. }\end{array}$ \\
\hline
\end{tabular}




\begin{tabular}{|c|c|c|}
\hline Aspect of the Report & Critiquing Questions & Detailed Critiquing Guidelines \\
\hline & $\begin{array}{l}\text { Were specific instruments } \\
\text { adequately described and were } \\
\text { they good choices, given the } \\
\text { study population and the } \\
\text { variables being studied? } \\
\text { Did the report provide evidence } \\
\text { that the data collection methods } \\
\text { yielded data that were reliable, } \\
\text { valid and responsive? }\end{array}$ & $\begin{array}{l}\text { A descriptive study for a sample of } \\
\text { veterans used the Duke Religious } \\
\text { Index and Internal State Scale. }\end{array}$ \\
\hline Procedures & $\begin{array}{l}\text { If there was an intervention, was } \\
\text { it adequately described, and was } \\
\text { it rigorously developed and } \\
\text { implemented? Did most } \\
\text { participants allocated to the } \\
\text { intervention group actually } \\
\text { receive it? Was there evidence } \\
\text { of intervention fidelity? } \\
\text { Were data collected in a manner } \\
\text { that minimized bias? Were the } \\
\text { staff who collected data } \\
\text { appropriately trained? }\end{array}$ & $\begin{array}{l}\text { No intervention was described for } \\
\text { this study. They did not mention } \\
\text { the level of training of the staff } \\
\text { collecting data in the original } \\
\text { studies. }\end{array}$ \\
\hline Data Analysis & $\begin{array}{l}\text { Were analyses undertaken to } \\
\text { address each research question } \\
\text { or test each hypothesis? } \\
\text { Were appropriate statistical } \\
\text { methods used, given the level of } \\
\text { measurement of the variables, } \\
\text { number of groups being } \\
\text { compared, and assumptions of } \\
\text { the texts? } \\
\text { Was a powerful analytic method } \\
\text { used? (e.g., did the analysis help } \\
\text { to control for confounding } \\
\text { variables)? } \\
\text { Were type I and Type II errors } \\
\text { avoided or minimized? } \\
\text { In intervention studies, was an } \\
\text { intention-to-treat analysis } \\
\text { performed? }\end{array}$ & $\begin{array}{l}\text { There were no statistical methods } \\
\text { used to analyze the data. }\end{array}$ \\
\hline $\begin{array}{l}\text { Data Analysis } \\
\text { (continued) }\end{array}$ & $\begin{array}{l}\text { Were problems of missing values } \\
\text { evaluated and adequately } \\
\text { addressed? }\end{array}$ & $\begin{array}{l}\text { The problem of missing values was } \\
\text { not addressed. }\end{array}$ \\
\hline Findings & $\begin{array}{l}\text { Was information about statistical } \\
\text { significance presented? Was } \\
\text { information about effect size and } \\
\text { precision of estimates }\end{array}$ & $\begin{array}{l}\text { Only one table summarizing the } \\
\text { main findings was presented. Five } \\
\text { studies were the sources of this } \\
\text { study. Intrinsic religiousness was }\end{array}$ \\
\hline
\end{tabular}




\begin{tabular}{|c|c|c|}
\hline Aspect of the Report & Critiquing Questions & Detailed Critiquing Guidelines \\
\hline & $\begin{array}{l}\text { (confidence intervals) presented? } \\
\text { Were the findings adequately } \\
\text { summarized, with good use of } \\
\text { tables and figures? } \\
\text { Were findings reported in a } \\
\text { manner that facilitates a meta- } \\
\text { analysis, and with sufficient } \\
\text { information needed for EBP? }\end{array}$ & $\begin{array}{l}\text { associated with fewer depression } \\
\text { and improved quality of life. } \\
\text { More data should be provided in } \\
\text { order for this study to be } \\
\text { considered for an EBP. }\end{array}$ \\
\hline $\begin{array}{l}\text { Discussion } \\
\text { Interpretation of the } \\
\text { findings }\end{array}$ & $\begin{array}{l}\text { Were all major findings } \\
\text { interpreted and discussed within } \\
\text { the context of prior research } \\
\text { and/or the study's conceptual } \\
\text { framework? } \\
\text { Were casual inferences, if any, } \\
\text { justified? } \\
\text { Was the issue of clinical } \\
\text { significance discussed? } \\
\text { Were interpretations well- } \\
\text { founded and consistent with the } \\
\text { study's limitations? } \\
\text { Did the report address the issue } \\
\text { of the generalizability of the } \\
\text { findings? }\end{array}$ & $\begin{array}{l}\text { The results were explained in the } \\
\text { context of prior studies. For } \\
\text { instance, they cited a study where } \\
\text { a sample of thirty patients with } \\
\text { Bipolar Disorder were surveyed. } \\
\text { These patients stated that } \\
\text { spirituality was an important part } \\
\text { of their lives. Another group of } \\
\text { one hundred and sixty-eight } \\
\text { patients evaluated according to } \\
\text { the World Health Organization } \\
\text { Quality of Life scale reported } \\
\text { fewer episodes of depression. } \\
\text { The limitations of the study were } \\
\text { not addressed, nor the } \\
\text { generalizability of the findings. }\end{array}$ \\
\hline $\begin{array}{l}\text { Implications/ } \\
\text { recommendations }\end{array}$ & $\begin{array}{l}\text { Did the researchers discuss the } \\
\text { implications of the study for } \\
\text { clinical practice or further } \\
\text { research-and were those } \\
\text { implications reasonable and } \\
\text { complete? }\end{array}$ & $\begin{array}{l}\text { They did not discuss the } \\
\text { implications of the study for } \\
\text { practice. }\end{array}$ \\
\hline $\begin{array}{l}\text { General Issues } \\
\text { Presentation }\end{array}$ & $\begin{array}{l}\text { Was the report well-written, } \\
\text { organized, and sufficiently } \\
\text { detailed for critical analysis? } \\
\text { In intervention studies, was a } \\
\text { CONSORT flowchart provided to } \\
\text { show the flow of participants in } \\
\text { the study? }\end{array}$ & $\begin{array}{l}\text { This report was well-written, but } \\
\text { not detailed enough for critical } \\
\text { analysis. A lot of data regarding } \\
\text { the population were missing. }\end{array}$ \\
\hline $\begin{array}{l}\text { General Issues } \\
\text { Presentation } \\
\text { (continued) } \\
\end{array}$ & $\begin{array}{l}\text { Was the report written in a } \\
\text { manner that makes the findings } \\
\text { accessible to practicing nurses? }\end{array}$ & $\begin{array}{l}\text { The report was easy to read and } \\
\text { available to practicing nurses. }\end{array}$ \\
\hline Researcher credibility & $\begin{array}{l}\text { Do the researchers' clinical, } \\
\text { substantive, or methodologic } \\
\text { qualifications and experience } \\
\text { enhance confidence in the } \\
\text { findings and their interpretation? }\end{array}$ & $\begin{array}{l}\text { The researchers' clinical } \\
\text { experience enhanced the quality } \\
\text { of this report. Their inquiry could } \\
\text { be considered as a stepping stone } \\
\text { for more research in this area. }\end{array}$ \\
\hline Summary assessment & Despite any limitations, do the & The findings were valid and the \\
\hline
\end{tabular}




\begin{tabular}{|l|l|l|}
\hline Aspect of the Report & Critiquing Questions & Detailed Critiquing Guidelines \\
\hline & $\begin{array}{l}\text { study findings appear to be } \\
\text { valid-do you have confidence in } \\
\text { the truth value of the results? } \\
\text { Does the study contribute any } \\
\text { meaningful evidence that can be } \\
\text { used in nursing practice or that is } \\
\text { useful to the nursing discipline? }\end{array}$ & $\begin{array}{l}\text { results were credible. They can } \\
\text { certainly be used in nursing to } \\
\text { increase awareness about the role } \\
\text { of spirituality in health outcomes. }\end{array}$ \\
\hline
\end{tabular}




\section{Appendix A-9}

\section{Table 9}

\begin{tabular}{|c|c|c|}
\hline Aspect of the Report & Critiquing Questions & Detailed Critiquing Guidelines \\
\hline $\begin{array}{l}\text { Title } \\
\text { Looking at infertility } \\
\text { through the lens of } \\
\text { religion and spirituality: } \\
\text { a review of the } \\
\text { literature. } \\
\text { Rousdari, R.L., Allan, } \\
\text { H.T., \& Smith, P.A. } \\
\text { (2007). }\end{array}$ & $\begin{array}{l}\text { Is the title a good one, succinctly } \\
\text { suggesting key variables and the } \\
\text { study population? }\end{array}$ & $\begin{array}{l}\text { The title suggested the key } \\
\text { problem which is infertility, and } \\
\text { the group under study was } \\
\text { infertile women. }\end{array}$ \\
\hline Abstract & $\begin{array}{l}\text { Did the abstract clearly and } \\
\text { concisely summarize the main } \\
\text { features of the report (problem, } \\
\text { methods, results, conclusions)? }\end{array}$ & $\begin{array}{l}\text { The abstract summarized the } \\
\text { main ideas of the study which are } \\
\text { infertility, religion, spirituality, } \\
\text { holistic care, reproductive } \\
\text { technology. }\end{array}$ \\
\hline $\begin{array}{l}\text { Introduction } \\
\text { Statement of the } \\
\text { problem }\end{array}$ & $\begin{array}{l}\text { Was the problem stated } \\
\text { unambiguously, and was it easy } \\
\text { to identify? } \\
\text { Is the problem statement build a } \\
\text { persuasive argument for the new } \\
\text { study? } \\
\text { Was there a good match } \\
\text { between the research problem } \\
\text { and the methods used -that is, } \\
\text { was a quantitative approach } \\
\text { appropriate? }\end{array}$ & $\begin{array}{l}\text { The problem was stated as a lack } \\
\text { of literature that addressed the } \\
\text { spiritual and religious aspects of } \\
\text { infertility. It built a strong case } \\
\text { for the new study given the } \\
\text { renewed attention that holistic } \\
\text { care is gaining now. } \\
\text { The problem is significant for } \\
\text { nursing given the devastating } \\
\text { consequences of infertility in } \\
\text { women particularly. }\end{array}$ \\
\hline $\begin{array}{l}\text { Hypotheses or research } \\
\text { questions }\end{array}$ & $\begin{array}{l}\text { Were research questions and/or } \\
\text { hypotheses explicitly stated? If } \\
\text { not, was their absence justified? } \\
\text { Were questions and hypotheses } \\
\text { appropriately worded, with clear } \\
\text { specification of key variables and } \\
\text { the study population? } \\
\text { Were the questions/hypotheses } \\
\text { consistent with existing } \\
\text { knowledge? }\end{array}$ & $\begin{array}{l}\text { The research questions were not } \\
\text { explicit, but the writers } \\
\text { questioned the fact that there } \\
\text { were few data available on the } \\
\text { role of spiritual care in infertile } \\
\text { women. The implied questions } \\
\text { were consistent with a tradition } \\
\text { that sometimes disregards the } \\
\text { role of spiritual care. }\end{array}$ \\
\hline Literature review & $\begin{array}{l}\text { Was the literature review up-to- } \\
\text { date and based mainly on } \\
\text { primary sources? } \\
\text { Did the review provide a state- } \\
\text { of-the-art synthesis of evidence } \\
\text { on the problem? } \\
\text { Did the literature review provide }\end{array}$ & $\begin{array}{l}\text { This report provided a } \\
\text { retrospective review of the } \\
\text { literature on the subject from } \\
1985 \text { to } 2007 \text { that paved the way } \\
\text { for the new inquiry. }\end{array}$ \\
\hline
\end{tabular}




\begin{tabular}{|c|c|c|}
\hline Aspect of the Report & Critiquing Questions & Detailed Critiquing Guidelines \\
\hline & a strong basis for the new study? & \\
\hline $\begin{array}{l}\text { Conceptual/theoretical } \\
\text { framework }\end{array}$ & $\begin{array}{l}\text { Were key concepts adequately } \\
\text { defined conceptually? } \\
\text { Was a conceptual/theoretical } \\
\text { framework articulated-and, if } \\
\text { so, was it appropriate? If not, is } \\
\text { the absence of a framework } \\
\text { justified? } \\
\text { Were the questions/hypotheses } \\
\text { consistent with the framework? }\end{array}$ & $\begin{array}{l}\text { Key concepts like religion and } \\
\text { spirituality that are used } \\
\text { interchangeably in the literature } \\
\text { were described separately. } \\
\text { There was not a particular } \\
\text { theoretical framework supporting } \\
\text { this study. }\end{array}$ \\
\hline $\begin{array}{l}\text { Method } \\
\text { Protection of human } \\
\text { rights }\end{array}$ & $\begin{array}{l}\text { Were appropriate procedures } \\
\text { used to safe-guard the rights of } \\
\text { study participants? } \\
\text { Was the study externally } \\
\text { reviewed by an IRB/ethics } \\
\text { review board? } \\
\text { Was the study designed to } \\
\text { minimize risks and maximize } \\
\text { benefits to participants? }\end{array}$ & $\begin{array}{l}\text { Human subjects were not directly } \\
\text { involved in this study. }\end{array}$ \\
\hline Research design & $\begin{array}{l}\text { Was the most rigorous design } \\
\text { used, given the study purpose? } \\
\text { Were appropriate comparisons } \\
\text { made to enhance interpretability } \\
\text { of the findings? } \\
\text { Was the number of data } \\
\text { collection points appropriate? } \\
\text { Did the design minimize biases } \\
\text { and threats to the internal, } \\
\text { construct, and external validity } \\
\text { of the study (e.g., was blinding } \\
\text { used, was attrition minimized)? }\end{array}$ & $\begin{array}{l}\text { The design used to collect and } \\
\text { analyze data is a quantitative } \\
\text { study in which data were } \\
\text { collected about women dealing } \\
\text { with infertility. } \\
\text { The coping strategies used by } \\
\text { these women depending on their } \\
\text { belief system enhanced the } \\
\text { interpretability of the findings. }\end{array}$ \\
\hline Population and sample & $\begin{array}{l}\text { Was the population identified? } \\
\text { Was the sample described in } \\
\text { sufficient detail? } \\
\text { Was the best possible sampling } \\
\text { design used to enhance the } \\
\text { sample's representativeness? } \\
\text { Were sampling biases } \\
\text { minimized? Was the sample size } \\
\text { Was the sample size based on a } \\
\text { power analysis? }\end{array}$ & $\begin{array}{l}\text { Infertile women were the focus } \\
\text { of the inquiry, but there were no } \\
\text { demographic data available on } \\
\text { them. } \\
\text { Power analysis was not a deciding } \\
\text { factor in the sample size. }\end{array}$ \\
\hline $\begin{array}{l}\text { Data collection and } \\
\text { measurement }\end{array}$ & $\begin{array}{l}\text { Were the operational and } \\
\text { conceptual definitions } \\
\text { congruent? } \\
\text { Were key variables measured }\end{array}$ & $\begin{array}{l}\text { Data were collected through } \\
\text { previous articles and studies. } \\
\text { The data collected offered } \\
\text { different perspectives on the way }\end{array}$ \\
\hline
\end{tabular}




\begin{tabular}{|c|c|c|}
\hline Aspect of the Report & Critiquing Questions & Detailed Critiquing Guidelines \\
\hline & $\begin{array}{l}\text { using an appropriate method } \\
\text { (e.g., interviews, observations, } \\
\text { and so on)? } \\
\text { Were specific instruments } \\
\text { adequately described and were } \\
\text { they good choices, given the } \\
\text { study population and the } \\
\text { variables being studied? } \\
\text { Did the report provide evidence } \\
\text { that the data collection methods } \\
\text { yielded data that were reliable, } \\
\text { valid and responsive? }\end{array}$ & $\begin{array}{l}\text { women coped with infertility. } \\
\text { Some relied on medical care } \\
\text { while others used the services of } \\
\text { healers, depending on their } \\
\text { beliefs. They also mentioned the } \\
\text { role of religious beliefs in } \\
\text { deciding or not to have an IVF for } \\
\text { instance. }\end{array}$ \\
\hline Procedures & $\begin{array}{l}\text { If there was an intervention, was } \\
\text { it adequately described, and was } \\
\text { it rigorously developed and } \\
\text { implemented? Did most } \\
\text { participants allocated to the } \\
\text { intervention group actually } \\
\text { receive it? Was there evidence } \\
\text { of intervention fidelity? } \\
\text { Were data collected in a manner } \\
\text { that minimized bias? Were the } \\
\text { staff who collected data } \\
\text { appropriately trained? }\end{array}$ & $\begin{array}{l}\text { There was no intervention } \\
\text { described in this study. }\end{array}$ \\
\hline Data Analysis & $\begin{array}{l}\text { Were analyses undertaken to } \\
\text { address each research question } \\
\text { or test each hypothesis? } \\
\text { Were appropriate statistical } \\
\text { methods used, given the level of } \\
\text { measurement of the variables, } \\
\text { number of groups being } \\
\text { compared, and assumptions of } \\
\text { the texts? } \\
\text { Was a powerful analytic method } \\
\text { used? (e.g., did the analysis help } \\
\text { to control for confounding } \\
\text { variables)? } \\
\text { Were type I and Type II errors } \\
\text { avoided or minimized? } \\
\text { In intervention studies, was an } \\
\text { intention-to-treat analysis } \\
\text { performed? }\end{array}$ & $\begin{array}{l}\text { There were no statistical } \\
\text { methods used for data analysis. }\end{array}$ \\
\hline $\begin{array}{l}\text { Data Analysis } \\
\text { (continued) }\end{array}$ & $\begin{array}{l}\text { Were problems of missing values } \\
\text { evaluated and adequately } \\
\text { addressed? }\end{array}$ & $\begin{array}{l}\text { There was not a problem of } \\
\text { missing values raised. }\end{array}$ \\
\hline
\end{tabular}




\begin{tabular}{|c|c|c|}
\hline Aspect of the Report & Critiquing Questions & Detailed Critiquing Guidelines \\
\hline Findings & $\begin{array}{l}\text { Was information about } \\
\text { statistical significance } \\
\text { presented? Was information } \\
\text { about effect size and precision of } \\
\text { estimates (confidence intervals) } \\
\text { presented? } \\
\text { Were the findings adequately } \\
\text { summarized, with good use of } \\
\text { tables and figures? } \\
\text { Were findings reported in a } \\
\text { manner that facilitates a meta- } \\
\text { analysis, and with sufficient } \\
\text { information needed for EBP? }\end{array}$ & $\begin{array}{l}\text { The findings were summarized } \\
\text { with supportive references on } \\
\text { different coping strategies used } \\
\text { by these women. Some women } \\
\text { used prayers, others consulted } \\
\text { healers, while others used in- } \\
\text { vitro fertilization. } \\
\text { This study offered a different } \\
\text { perspective of the concept of } \\
\text { infertility, the barriers that } \\
\text { religion sometimes represents in } \\
\text { these women quest for a } \\
\text { solution. }\end{array}$ \\
\hline $\begin{array}{l}\text { Discussion } \\
\text { Interpretation of the } \\
\text { findings }\end{array}$ & $\begin{array}{l}\text { Were all major findings } \\
\text { interpreted and discussed within } \\
\text { the context of prior research } \\
\text { and/or the study's conceptual } \\
\text { framework? } \\
\text { Were casual inferences, if any, } \\
\text { justified? } \\
\text { Was the issue of clinical } \\
\text { significance discussed? } \\
\text { Were interpretations well- } \\
\text { founded and consistent with the } \\
\text { study's limitations? } \\
\text { Did the report address the issue } \\
\text { of the generalizability of the } \\
\text { findings? }\end{array}$ & $\begin{array}{l}\text { The findings were consistent with } \\
\text { previous knowledge that there } \\
\text { was a lack of studies that } \\
\text { assessed the spiritual dimension } \\
\text { of infertility. } \\
\text { This study also pointed a cultural } \\
\text { dimension in infertility that } \\
\text { exposed women to more scrutiny } \\
\text { and testing even if the male } \\
\text { partner was the source of the } \\
\text { couple's infertility. }\end{array}$ \\
\hline $\begin{array}{l}\text { Implications/ } \\
\text { recommendations }\end{array}$ & $\begin{array}{l}\text { Did the researchers discuss the } \\
\text { implications of the study for } \\
\text { clinical practice or further } \\
\text { research-and were those } \\
\text { implications reasonable and } \\
\text { complete? }\end{array}$ & $\begin{array}{l}\text { They reiterated the role of } \\
\text { providers in helping patients find } \\
\text { meaning and self-worth in the } \\
\text { face of infertility. }\end{array}$ \\
\hline $\begin{array}{l}\text { General Issues } \\
\text { Presentation }\end{array}$ & $\begin{array}{l}\text { Was the report well-written, } \\
\text { organized, and sufficiently } \\
\text { detailed for critical analysis? } \\
\text { In intervention studies, was a } \\
\text { CONSORT flowchart provided to } \\
\text { show the flow of participants in } \\
\text { the study? }\end{array}$ & $\begin{array}{l}\text { This study was well-written, } \\
\text { detailed, and could potentially } \\
\text { serve as basis for analysis. }\end{array}$ \\
\hline $\begin{array}{l}\text { General Issues } \\
\text { Presentation } \\
\text { (continued) }\end{array}$ & $\begin{array}{l}\text { Was the report written in a } \\
\text { manner that makes the findings } \\
\text { accessible to practicing nurses? }\end{array}$ & $\begin{array}{l}\text { The report was easy to read, and } \\
\text { accessible to practicing nurses. }\end{array}$ \\
\hline Researcher credibility & $\begin{array}{l}\text { Do the researchers' clinical, } \\
\text { substantive, or methodologic }\end{array}$ & $\begin{array}{l}\text { The authors are scholars } \\
\text { affiliated with the University of }\end{array}$ \\
\hline
\end{tabular}




\begin{tabular}{|l|l|l|}
\hline Aspect of the Report & Critiquing Questions & Detailed Critiquing Guidelines \\
\hline & $\begin{array}{l}\text { qualifications and experience } \\
\text { enhance confidence in the } \\
\text { findings and their } \\
\text { interpretation? }\end{array}$ & $\begin{array}{l}\text { Surrey in the United Kingdom. } \\
\text { Their qualifications enhance the } \\
\text { confidence in the findings and } \\
\text { their interpretation }\end{array}$ \\
\hline Summary assessment & $\begin{array}{l}\text { Despite any limitations, do the } \\
\text { study findings appear to be } \\
\text { valid-do you have confidence in } \\
\text { the truth value of the results? } \\
\text { Does the study contribute any } \\
\text { meaningful evidence that can be } \\
\text { used in nursing practice or that is } \\
\text { useful to the nursing discipline? }\end{array}$ & $\begin{array}{l}\text { The study is trustworthy and can } \\
\text { contribute greatly to the nursing } \\
\text { discipline. It encouraged further } \\
\text { research in the field of } \\
\text { spirituality/religion in order to } \\
\text { provide holistic care. }\end{array}$ \\
\hline
\end{tabular}




\section{Appendix A-10}

\section{Table 10}

\begin{tabular}{|c|c|c|}
\hline Aspect of the Report & Critiquing Questions & Detailed Critiquing Guidelines \\
\hline $\begin{array}{l}\text { Title } \\
\text { Religion, spirituality, and } \\
\text { mental health of U.S. } \\
\text { military veterans: } \\
\text { Results from the } \\
\text { National Health and } \\
\text { Resilience in Veterans } \\
\text { Study. } \\
\text { Sharma, V., Marin, D.B., } \\
\text { Koenig, H.K., Feder, } \\
\text { A., lacoviello, } \\
\text { B.M.,...Pietrzak, R.H. } \\
\text { (2017). }\end{array}$ & $\begin{array}{l}\text { Is the title a good one, succinctly } \\
\text { suggesting key variables and the } \\
\text { study population? }\end{array}$ & $\begin{array}{l}\text { The title suggested the key } \\
\text { variables such as religion, } \\
\text { spirituality and mental health and } \\
\text { US military Veterans as the study } \\
\text { population. }\end{array}$ \\
\hline Abstract & $\begin{array}{l}\text { Did the abstract clearly and } \\
\text { concisely summarize the main } \\
\text { features of the report (problem, } \\
\text { methods, results, conclusions)? }\end{array}$ & $\begin{array}{l}\text { The abstract summarized the } \\
\text { main features of the article: } \\
\text { background, methods, results, } \\
\text { and conclusions. }\end{array}$ \\
\hline $\begin{array}{l}\text { Introduction } \\
\text { Statement of the } \\
\text { problem }\end{array}$ & $\begin{array}{l}\text { Was the problem stated } \\
\text { unambiguously, and was it easy } \\
\text { to identify? } \\
\text { Is the problem statement build a } \\
\text { persuasive argument for the } \\
\text { new study? } \\
\text { Was there a good match } \\
\text { between the research problem } \\
\text { and the methods used -that is, } \\
\text { was a quantitative approach } \\
\text { appropriate? }\end{array}$ & $\begin{array}{l}\text { The problem was not clearly } \\
\text { stated, but reading along the } \\
\text { lines, it was obvious that there } \\
\text { were a limited number of studies } \\
\text { about the relationship between } \\
\text { spirituality and mental health } \\
\text { outcomes in military Veterans in } \\
\text { the United States. }\end{array}$ \\
\hline $\begin{array}{l}\text { Hypotheses or research } \\
\text { questions }\end{array}$ & $\begin{array}{l}\text { Were research questions and/or } \\
\text { hypotheses explicitly stated? If } \\
\text { not, was their absence justified? } \\
\text { Were questions and hypotheses } \\
\text { appropriately worded, with } \\
\text { clear specification of key } \\
\text { variables and the study } \\
\text { population? } \\
\text { Were the questions/hypotheses } \\
\text { consistent with existing } \\
\text { knowledge? }\end{array}$ & $\begin{array}{l}\text { The research questions were } \\
\text { formulated in terms of aims. The } \\
\text { first one was to examine the } \\
\text { relationship between } \\
\text { religion/spirituality and mental } \\
\text { health outcomes. The second was } \\
\text { to discuss the influences of } \\
\text { spirituality on quality of life and } \\
\text { resilience. }\end{array}$ \\
\hline
\end{tabular}




\begin{tabular}{|c|c|c|}
\hline Aspect of the Report & Critiquing Questions & Detailed Critiquing Guidelines \\
\hline Literature review & $\begin{array}{l}\text { Was the literature review up-to- } \\
\text { date and based mainly on } \\
\text { primary sources? } \\
\text { Did the review provide a state- } \\
\text { of-the-art synthesis of evidence } \\
\text { on the problem? } \\
\text { Did the literature review provide } \\
\text { a strong basis for the new } \\
\text { study? }\end{array}$ & $\begin{array}{l}\text { The authors reviewed the } \\
\text { literature related to the topic, but } \\
\text { they also acknowledged certain } \\
\text { limitations stemming from the } \\
\text { fact that the studies were limited } \\
\text { to the veterans treated in } \\
\text { primary care and mental health } \\
\text { settings. }\end{array}$ \\
\hline Population and sample & $\begin{array}{l}\text { Was the population identified? } \\
\text { Was the sample described in } \\
\text { sufficient detail? } \\
\text { Was the best possible sampling } \\
\text { design used to enhance the } \\
\text { sample's representativeness? } \\
\text { Were sampling biases } \\
\text { minimized? } \\
\text { Was the sample size based on a } \\
\text { power analysis? }\end{array}$ & $\begin{array}{l}\text { The participants were composed } \\
\text { of } 3157 \text { U.S. Veterans who have } \\
\text { served between October and } \\
\text { December } 2011 \text { and who have } \\
\text { completed an anonymous online } \\
\text { survey. } \\
\text { This sample was taken from a } \\
\text { population of more than } 50.000 \\
\text { households, at least } 18 \text { years old, } \\
\text { and using only cell-phones. }\end{array}$ \\
\hline $\begin{array}{l}\text { Conceptual/theoretical } \\
\text { framework }\end{array}$ & $\begin{array}{l}\text { Were key concepts adequately } \\
\text { defined conceptually? } \\
\text { Was a conceptual/theoretical } \\
\text { framework articulated-and, if } \\
\text { so, was it appropriate? If not, is } \\
\text { the absence of a framework } \\
\text { justified? } \\
\text { Were the questions/hypotheses } \\
\text { consistent with the framework? }\end{array}$ & $\begin{array}{l}\text { Key concepts such as religion, } \\
\text { spirituality, were not defined. } \\
\text { There was not a theoretical } \\
\text { framework guiding this study. }\end{array}$ \\
\hline $\begin{array}{l}\text { Method } \\
\text { Protection of human } \\
\text { rights }\end{array}$ & $\begin{array}{l}\text { Were appropriate procedures } \\
\text { used to safe-guard the rights of } \\
\text { study participants? } \\
\text { Was the study externally } \\
\text { reviewed by an IRB/ethics } \\
\text { review board? } \\
\text { Was the study designed to } \\
\text { minimize risks and maximize } \\
\text { benefits to participants? }\end{array}$ & $\begin{array}{l}\text { This study was authorized by the } \\
\text { Human Subjects Subcommittee of } \\
\text { the VA Connecticut Healthcare } \\
\text { System and the VA Office of } \\
\text { Research and Development. }\end{array}$ \\
\hline Research design & $\begin{array}{l}\text { Was the most rigorous design } \\
\text { used, given the study purpose? } \\
\text { Were appropriate comparisons } \\
\text { made to enhance } \\
\text { interpretability of the findings? } \\
\text { Was the number of data }\end{array}$ & $\begin{array}{l}\text { The researchers used a cross- } \\
\text { sectional design to complete this } \\
\text { study. } \\
\text { Sociodemographic, military, and } \\
\text { clinical variables were compared } \\
\text { to facilitate the interpretability of }\end{array}$ \\
\hline
\end{tabular}




\begin{tabular}{|c|c|c|}
\hline Aspect of the Report & Critiquing Questions & Detailed Critiquing Guidelines \\
\hline & $\begin{array}{l}\text { collection points appropriate? } \\
\text { Did the design minimize biases } \\
\text { and threats to the internal, } \\
\text { construct, and external validity } \\
\text { of the study (e.g., was blinding } \\
\text { used, was attrition minimized)? }\end{array}$ & data. \\
\hline $\begin{array}{l}\text { Data collection and } \\
\text { measurement }\end{array}$ & $\begin{array}{l}\text { Were the operational and } \\
\text { conceptual definitions } \\
\text { congruent? } \\
\text { Were key variables measured } \\
\text { using an appropriate method } \\
\text { (e.g., interviews, observations, } \\
\text { and so on)? } \\
\text { Were specific instruments } \\
\text { adequately described and were } \\
\text { they good choices, given the } \\
\text { study population and the } \\
\text { variables being studied? } \\
\text { Did the report provide evidence } \\
\text { that the data collection methods } \\
\text { yielded data that were reliable, } \\
\text { valid and responsive? }\end{array}$ & $\begin{array}{l}\text { The participants were reached via } \\
\text { an online survey. Their } \\
\text { religious/spiritual background } \\
\text { was assessed using a 5-item scale } \\
\text { developed by the Duke University } \\
\text { Religion Index (DUREL) that } \\
\text { measures organizational religious } \\
\text { activities, non-organizational } \\
\text { religious activities, and intrinsic } \\
\text { religiosity. }\end{array}$ \\
\hline Procedures & $\begin{array}{l}\text { If there was an intervention, } \\
\text { was it adequately described, } \\
\text { and was it rigorously developed } \\
\text { and implemented? Did most } \\
\text { participants allocated to the } \\
\text { intervention group actually } \\
\text { receive it? Was there evidence } \\
\text { of intervention fidelity? } \\
\text { Were data collected in a manner } \\
\text { that minimized bias? Were the } \\
\text { staff who collected data } \\
\text { appropriately trained? }\end{array}$ & $\begin{array}{l}\text { The researchers formed three } \\
\text { groups based on the 5-item } \\
\text { DUREL scale: low } \\
\text { religion/spirituality, moderate } \\
\text { religion/spirituality, high } \\
\text { religion/spirituality, depending } \\
\text { on their level of religious } \\
\text { engagement. }\end{array}$ \\
\hline
\end{tabular}




\begin{tabular}{|c|c|c|}
\hline Aspect of the Report & Critiquing Questions & Detailed Critiquing Guidelines \\
\hline Data Analysis & $\begin{array}{l}\text { Were analyses undertaken to } \\
\text { address each research question } \\
\text { or test each hypothesis? } \\
\text { Were appropriate statistical } \\
\text { methods used, given the level of } \\
\text { measurement of the variables, } \\
\text { number of groups being } \\
\text { compared, and assumptions of } \\
\text { the texts? } \\
\text { Was a powerful analytic method } \\
\text { used? (e.g., did the analysis } \\
\text { help to control for confounding } \\
\text { variables)? } \\
\text { Were type I and Type II errors } \\
\text { avoided or minimized? } \\
\text { In intervention studies, was an } \\
\text { intention-to-treat analysis } \\
\text { performed? } \\
\text { Were problems of missing } \\
\text { values evaluated and } \\
\text { adequately addressed? }\end{array}$ & $\begin{array}{l}\text { They compared Socio- } \\
\text { demographic, military, and } \\
\text { clinical characteristics using t- } \\
\text { tests for continuous variables, } \\
\text { and chi-square to evaluate } \\
\text { demographic data. Covariance } \\
\text { was used to determine the } \\
\text { relationship between dependent } \\
\text { and independent variables. } \\
\text { The statistical software IBM SPSS } \\
\text { Statistics Version } 22 \text { was used. } \\
\text { The authors did not mention any } \\
\text { missing values. }\end{array}$ \\
\hline Findings & $\begin{array}{l}\text { Was information about } \\
\text { statistical significance } \\
\text { presented? Was information } \\
\text { about effect size and precision } \\
\text { of estimates (confidence } \\
\text { intervals) presented? } \\
\text { Were the findings adequately } \\
\text { summarized, with good use of } \\
\text { tables and figures? } \\
\text { Were findings reported in a } \\
\text { manner that facilitates a meta- } \\
\text { analysis, and with sufficient } \\
\text { information needed for EBP? }\end{array}$ & $\begin{array}{l}\text { The findings were presented in } \\
\text { tables displaying the } \\
\text { demographic characteristics of } \\
\text { different groups of veterans. } \\
\text { Most of the veterans were aged } \\
\text { between } 60 \text { and } 79 \text { years old, } \\
\text { were white and educated. } \\
\text { Psychiatric variables were } \\
\text { presented in another table and } \\
\text { provided evidence that } \\
\text { spirituality positively affects US } \\
\text { military Veterans' mental health. } \\
\text { According to the study, the odds } \\
\text { of having PTSD, depression, and } \\
\text { alcohol use disorder was less } \\
\text { likely in people with a higher } \\
\text { religious / spiritual background. } \\
\text { Quality of life was also rated } \\
\text { higher in people with a stronger } \\
\text { spiritual background. }\end{array}$ \\
\hline $\begin{array}{l}\text { Discussion } \\
\text { Interpretation of the } \\
\text { findings }\end{array}$ & $\begin{array}{l}\text { Were all major findings } \\
\text { interpreted and discussed within } \\
\text { the context of prior research } \\
\text { and/or the study's conceptual } \\
\text { framework? }\end{array}$ & $\begin{array}{l}\text { The findings suggested that } \\
\text { spirituality/ religion played a } \\
\text { positive role in psychosocial traits } \\
\text { such as resilience, altruist } \\
\text { behaviors. The authors noted }\end{array}$ \\
\hline
\end{tabular}




\begin{tabular}{|c|c|c|}
\hline Aspect of the Report & Critiquing Questions & Detailed Critiquing Guidelines \\
\hline & $\begin{array}{l}\text { Were casual inferences, if any, } \\
\text { justified? } \\
\text { Was the issue of clinical } \\
\text { significance discussed? } \\
\text { Were interpretations well- } \\
\text { founded and consistent with the } \\
\text { study's limitations? } \\
\text { Did the report address the issue } \\
\text { of the generalizability of the } \\
\text { findings? }\end{array}$ & $\begin{array}{l}\text { that religious beliefs and } \\
\text { practices in general were } \\
\text { beneficial to mental health } \\
\text { regardless of their types. The } \\
\text { ability to generalize the findings } \\
\text { was restricted because the } \\
\text { sample was limited to older } \\
\text { Veterans, and by the fact that } \\
\text { sample sizes changed depending } \\
\text { on whether the participants had a } \\
\text { low, moderate or a high } \\
\text { religious/spiritual background. }\end{array}$ \\
\hline $\begin{array}{l}\text { Implications/ } \\
\text { recommendations }\end{array}$ & $\begin{array}{l}\text { Did the researchers discuss the } \\
\text { implications of the study for } \\
\text { clinical practice or further } \\
\text { research-and were those } \\
\text { implications reasonable and } \\
\text { complete? }\end{array}$ & $\begin{array}{l}\text { They recommended a routine } \\
\text { assessment and monitoring of } \\
\text { religious and spiritual beliefs in } \\
\text { treatment settings and } \\
\text { encouraged further research in } \\
\text { veterans and other at-risk groups. }\end{array}$ \\
\hline $\begin{array}{l}\text { General Issues } \\
\text { Presentation }\end{array}$ & $\begin{array}{l}\text { Was the report well-written, } \\
\text { organized, and sufficiently } \\
\text { detailed for critical analysis? } \\
\text { In intervention studies, was a } \\
\text { CONSORT flowchart provided to } \\
\text { show the flow of participants in } \\
\text { the study? } \\
\text { Was the report written in a } \\
\text { manner that makes the findings } \\
\text { accessible to practicing nurses? }\end{array}$ & $\begin{array}{l}\text { The study provided an organized } \\
\text { and well-written report, but the } \\
\text { demographic data were limited } \\
\text { to older veterans. The description } \\
\text { of the methods, the findings, and } \\
\text { the interpretations were rich in } \\
\text { details. Several tables were } \\
\text { presented to further expose their } \\
\text { findings. }\end{array}$ \\
\hline Researcher credibility & $\begin{array}{l}\text { Do the researchers' clinical, } \\
\text { substantive, or methodologic } \\
\text { qualifications and experience } \\
\text { enhance confidence in the } \\
\text { findings and their } \\
\text { interpretation? }\end{array}$ & $\begin{array}{l}\text { The researchers' background in } \\
\text { the fields of Psychiatry, } \\
\text { spirituality left no doubt about } \\
\text { their qualifications to conduct } \\
\text { this kind of research. }\end{array}$ \\
\hline Summary assessment & $\begin{array}{l}\text { Despite any limitations, do the } \\
\text { study findings appear to be } \\
\text { valid-do you have confidence } \\
\text { in the truth value of the results? } \\
\text { Does the study contribute any } \\
\text { meaningful evidence that can be } \\
\text { used in nursing practice or that } \\
\text { is useful to the nursing } \\
\text { discipline? }\end{array}$ & $\begin{array}{l}\text { The findings were credible } \\
\text { because they were collected by } \\
\text { knowledgeable professionals. } \\
\text { Those data could be used in } \\
\text { nursing practice to assess } \\
\text { patients' beliefs in order to } \\
\text { provide more personalized care. }\end{array}$ \\
\hline
\end{tabular}




\section{Appendix B}

\begin{tabular}{|c|c|c|c|c|}
\hline Authors & Literature type & Strengths/Limitations & Key results & Implications \\
\hline $\begin{array}{l}\text { Ironson, G., } \\
\text { Stuetzle, R., \& } \\
\text { Fletcher, M.A. } \\
\text { (2006) }\end{array}$ & $\begin{array}{l}\text { Longitudinal } \\
\text { study }\end{array}$ & $\begin{array}{l}\text { This study could not } \\
\text { establish that an } \\
\text { increase in } \\
\text { spirituality/religiosity } \\
\text { alone led to an } \\
\text { increase in CD4 and a } \\
\text { decreased viral load } \\
\text { without any positive } \\
\text { behaviors like safe sex } \\
\text { or smoking cessation. }\end{array}$ & $\begin{array}{l}\text { Increased } \\
\text { spirituality } \\
\text { coincided } \\
\text { with slower } \\
\text { disease } \\
\text { progression, } \\
\text { longevity, } \\
\text { and a better } \\
\text { quality of } \\
\text { life. }\end{array}$ & $\begin{array}{l}\text { Providers } \\
\text { encouraged } \\
\text { to be more } \\
\text { receptive to } \\
\text { patients' } \\
\text { spiritual } \\
\text { needs. }\end{array}$ \\
\hline $\begin{array}{l}\text { Watlington, } \\
\text { C.G.\& } \\
\text { Murphy, C.M. } \\
\text { (2006) }\end{array}$ & $\begin{array}{l}\text { Cross-sectional } \\
\text { study }\end{array}$ & $\begin{array}{l}\text { Sampling, sample size, } \\
\text { study design, method } \\
\text { of data collection, and } \\
\text { the quantitative nature } \\
\text { of the study. }\end{array}$ & $\begin{array}{l}\text { Religious } \\
\text { involvement } \\
\text { linked with } \\
\text { higher social } \\
\text { support, } \\
\text { lower } \\
\text { depression, } \\
\text { and PTSD. }\end{array}$ & $\begin{array}{l}\text { The authors } \\
\text { stressed the } \\
\text { importance } \\
\text { of delivering } \\
\text { culturally } \\
\text { sensitive } \\
\text { care. }\end{array}$ \\
\hline $\begin{array}{l}\text { Roudsari, R.L., } \\
\text { Allan, H.T.,\& } \\
\text { Smith, P.A. } \\
\text { (2007) }\end{array}$ & $\begin{array}{l}\text { Review of the } \\
\text { literature }\end{array}$ & $\begin{array}{l}\text { This review focused on } \\
\text { infertility in women } \\
\text { primarily leaving out } \\
\text { infertility issues in men. }\end{array}$ & $\begin{array}{l}\text { The authors } \\
\text { identified a } \\
\text { gap in the } \\
\text { literature } \\
\text { related to } \\
\text { the religious } \\
\text { and spiritual } \\
\text { dimensions } \\
\text { of infertility } \\
\text { and } \\
\text { discussed the } \\
\text { impact of } \\
\text { spirituality/p } \\
\text { rayer on } \\
\text { infertility. }\end{array}$ & $\begin{array}{l}\text { The authors } \\
\text { noted that } \\
\text { providers are } \\
\text { often ill- } \\
\text { prepared to } \\
\text { assist } \\
\text { patients with } \\
\text { spiritual } \\
\text { needs, and } \\
\text { encouraged } \\
\text { routine } \\
\text { assessment } \\
\text { of } \\
\text { religious/spiri } \\
\text { tual needs. }\end{array}$ \\
\hline $\begin{array}{l}\text { Koenig, H.G. } \\
\text { (2009) }\end{array}$ & $\begin{array}{l}\text { Review of the } \\
\text { literature }\end{array}$ & $\begin{array}{l}\text { Clinical implications } \\
\text { were not addressed. } \\
\text { The review was } \\
\text { selective, not } \\
\text { systematic. }\end{array}$ & $\begin{array}{l}\text { The author } \\
\text { reported } \\
\text { that people } \\
\text { use religion } \\
\text { to cope with } \\
\text { mental } \\
\text { illnesses, and } \\
\text { that religious } \\
\text { involvement }\end{array}$ & $\begin{array}{l}\text { Clinical } \\
\text { applications } \\
\text { were not } \\
\text { addressed. }\end{array}$ \\
\hline
\end{tabular}




\begin{tabular}{|c|c|c|c|c|}
\hline Authors & Literature type & Strengths/Limitations & Key results & Implications \\
\hline & & & $\begin{array}{l}\text { allowed } \\
\text { better coping } \\
\text { with stress } \\
\text { and mental } \\
\text { illnesses. }\end{array}$ & \\
\hline $\begin{array}{l}\text { Snider, A.M.\& } \\
\text { McPhedran, S. } \\
\text { (2013) }\end{array}$ & $\begin{array}{l}\text { Systematic } \\
\text { literature review }\end{array}$ & $\begin{array}{l}\text { The authors mentioned } \\
\text { a limited literature on } \\
\text { religiosity in Australia. }\end{array}$ & $\begin{array}{l}\text { Spirituality/r } \\
\text { eligiosity } \\
\text { were related } \\
\text { to positive } \\
\text { outcomes } \\
\text { such as a } \\
\text { meaningful } \\
\text { life. }\end{array}$ & $\begin{array}{l}\text { Further } \\
\text { research into } \\
\text { religiosity/spi } \\
\text { rituality and } \\
\text { mental } \\
\text { health was } \\
\text { encouraged. }\end{array}$ \\
\hline $\begin{array}{l}\text { Jim, H.S.L., } \\
\text { Pustejovsky, } \\
\text { J.E.,Park,L.C., } \\
\text { Danhauer,S. } \\
\text { C., Sherman, } \\
\text { A.C. , Fitchett, } \\
\text { G.,...,\& } \\
\text { Salsman, J.M. } \\
\text { (2015). }\end{array}$ & Meta-analysis & $\begin{array}{l}\text { Innovative, large } \\
\text { sample, rigorous } \\
\text { statistical method. } \\
\text { Limitations: small } \\
\text { sample size, } \\
\text { incomplete data in the } \\
\text { method section. }\end{array}$ & $\begin{array}{l}\text { Cognitive } \\
\text { spirituality/ } \\
\text { Religion was } \\
\text { associated } \\
\text { with better } \\
\text { physical } \\
\text { health. } \\
\text { Meaningful } \\
\text { spiritual/relig } \\
\text { ious } \\
\text { experience } \\
\text { was } \\
\text { associated } \\
\text { with } \\
\text { emotional } \\
\text { stability. }\end{array}$ & $\begin{array}{l}\text { Spiritual and } \\
\text { cultural } \\
\text { approach to } \\
\text { care delivery } \\
\text { was } \\
\text { encouraged. }\end{array}$ \\
\hline $\begin{array}{l}\text { De Fazio, } \\
\text { P.,Gaetano, R., } \\
\text { Caroleo, M., } \\
\text { Cerminara, G., } \\
\text { Giannini, } \\
\text { F.,....,\& } \\
\text { Segura-Garcia, } \\
\text { C. (2015). }\end{array}$ & $\begin{array}{l}\text { Review of the } \\
\text { literature }\end{array}$ & $\begin{array}{l}\text { There were no } \\
\text { limitations issues } \\
\text { raised by the authors, } \\
\text { but the fact that they } \\
\text { based their review on } \\
\text { five studies limited the } \\
\text { scope of their findings. }\end{array}$ & $\begin{array}{l}\text { Intrinsic } \\
\text { religiousness } \\
\text { was } \\
\text { associated } \\
\text { with fewer } \\
\text { depression } \\
\text { and better } \\
\text { quality of } \\
\text { life. }\end{array}$ & $\begin{array}{l}\text { The authors } \\
\text { encouraged a } \\
\text { better } \\
\text { assessment } \\
\text { of } \\
\text { religiousness/ } \\
\text { spirituality by } \\
\text { providers. }\end{array}$ \\
\hline $\begin{array}{l}\text { Jors, K., } \\
\text { Bussing, A., } \\
\text { Hvidt, N.C., } \\
\text { \&Baumann, K. } \\
\text { (2015) }\end{array}$ & $\begin{array}{l}\text { Review of the } \\
\text { literature }\end{array}$ & $\begin{array}{l}\text { No data on disease- } \\
\text { specific prayer } \\
\text { activities were } \\
\text { presented, or the } \\
\text { difference between } \\
\text { patients' prayers and } \\
\text { those of healthy } \\
\text { individuals. A thorough }\end{array}$ & $\begin{array}{l}\text { Five types of } \\
\text { prayer were } \\
\text { identified } \\
\text { depending } \\
\text { on the } \\
\text { patients' } \\
\text { specific } \\
\text { needs. }\end{array}$ & $\begin{array}{l}\text { The authors } \\
\text { encouraged } \\
\text { practitioners } \\
\text { to use this } \\
\text { knowledge to } \\
\text { address } \\
\text { patients' } \\
\text { need for }\end{array}$ \\
\hline
\end{tabular}




\begin{tabular}{|c|c|c|c|c|}
\hline Authors & Literature type & Strengths/Limitations & Key results & Implications \\
\hline & & $\begin{array}{l}\text { appraisal of the review } \\
\text { was not provided. }\end{array}$ & & $\begin{array}{l}\text { prayer in the } \\
\text { care plan. }\end{array}$ \\
\hline $\begin{array}{l}\text { Sharma,V., } \\
\text { Marin, D.B., } \\
\text { Koenig, H.K., } \\
\text { Feder, A., } \\
\text { Iacoviello, } \\
\text { B.M.,\& } \\
\text { Pietrzak, R.H. } \\
\text { (2017). }\end{array}$ & $\begin{array}{l}\text { Cross-sectional } \\
\text { study }\end{array}$ & $\begin{array}{l}\text { Study design, sampling, } \\
\text { sample size, } \\
\text { incomplete data about } \\
\text { religious affiliations. }\end{array}$ & $\begin{array}{l}\text { Spirituality } \\
\text { positively } \\
\text { affected } \\
\text { military } \\
\text { veterans' } \\
\text { mental } \\
\text { health. The } \\
\text { odds of } \\
\text { having } \\
\text { depression, } \\
\text { PTSD, and } \\
\text { alcohol use } \\
\text { disorder was } \\
\text { less likely in } \\
\text { people with } \\
\text { higher } \\
\text { religious/spiri } \\
\text { tual } \\
\text { background. }\end{array}$ & $\begin{array}{l}\text { The authors } \\
\text { encouraged } \\
\text { routine } \\
\text { assessment } \\
\text { of religious } \\
\text { and spiritual } \\
\text { beliefs in } \\
\text { healthcare } \\
\text { settings and } \\
\text { more } \\
\text { research in } \\
\text { veterans and } \\
\text { other at-risk } \\
\text { groups. }\end{array}$ \\
\hline $\begin{array}{l}\text { Oji, V.U., } \\
\text { Hung, L.C., } \\
\text { Abbasgholizad } \\
\text { eh, R., } \\
\text { Hamilton, F.T., } \\
\text { Essien, E.J., \& } \\
\text { Nwulia, E. } \\
\text { (2017) }\end{array}$ & $\begin{array}{l}\text { Systematic } \\
\text { literature review }\end{array}$ & $\begin{array}{l}\text { Limitations were not } \\
\text { addressed in this } \\
\text { review. The authors } \\
\text { mentioned the term } \\
\text { faith on several } \\
\text { occasions, but did not } \\
\text { reveal any religious } \\
\text { affiliations. }\end{array}$ & $\begin{array}{l}\text { Spirituality } \\
\text { increased } \\
\text { adherence to } \\
\text { antiretroviral } \\
\text { treatment. } \\
\text { Poor } \\
\text { adherence } \\
\text { was linked to } \\
\text { lower } \\
\text { religious } \\
\text { belief scores. }\end{array}$ & $\begin{array}{l}\text { The authors } \\
\text { recommende } \\
\mathrm{d} \text { an } \\
\text { assessment } \\
\text { of spiritual } \\
\text { and religious } \\
\text { beliefs in HIV } \\
\text { positive } \\
\text { individuals } \\
\text { along with } \\
\text { depression } \\
\text { and } \\
\text { treatment. }\end{array}$ \\
\hline
\end{tabular}

